\title{
RELAÇÕES ECONÔMICAS ENTRE EDUCAÇÃO E PRODUTO SOCIAL DA AGRICULTURA
}

\author{
ERALDO GENIN FIORE
}

Engenheiro Agrônomo

Orientador: Prof. Dr. PAULO FERNANDO CIDADE DE ARAÚJO

Dissertação apresentada à Escola Superior de Agricultura "Luiz de Queiroz", Universidade de São Paulo, para obtenção do título de Mestre em Ciências, Área de Concentração: Economia Aplicada

\section{PIRACICABA}

Estado de São Paulo - Brasil

Setembro - 2001 
Dados Internacionais de Catalogação na Publicação (CIP)

DIVISÃo DE BIBLIOTECA E DOCUMENTAÇÃo - Campus "Luiz de Queiroz"/USP

Fiore, Eraldo Genin

Relações econômicas entre educação e produto social da agricultura / Eraldo Genin Fore. - - Piracicaba, 2001.

$114 \mathrm{p}$.

Dissertação (mestrado) - - Escola Superior de Agricultura Luiz de Queiroz, 2001. Bibliografia.

1. Agricultura 2. Capital humano 3. Crescimento econômico 4. Educação agrícola 5. Escolarização 6. Mercado de trabalho 7. Setor agrícola I. Titulo

CDD 
"Somos muitos Severinos

iguais em tudo na vida:

na mesma cabega grande

que a custo é que se equilibra, no mesmo ventre crescido sobre as mesmas pernas finas, e iguais também porque o sangue que usamos tem pouca tinta. e se somos Severinos iguais em tudo na vida, morremos de morte igual, mesma morte severina: que é a morte de que se morre de velbice antes dos trinta, de emboscada antes dos vinte, de fome um pouco por dia (de fraqueza e de doenga é que a morte severina ataca em qualquer idade, $e$ até gente não nascida). Somos muitos Severinos Iguais em tudo e na sina: a de abrandar estas pedras suando-se muito em cima, a de tentar despertar terra sempre mais extinta, $a$ de querer arrancar algum roçado da cinza."

João Cabral de Melo Neto 


\section{AGRADECIMENTOS}

Aos meus pais. Não saberia como ou a que especificamente agradecê-los, a lista seria longa demais, por isso digo apenas: aos meus pais.

Ao meu orientador, professor e amigo Paulo Cidade, com quem tive mais do que aulas de economia e orientação neste trabalho, devo dizer, mesmo correndo o risco de usar um clichê, que tive lições de vida.

A todos meus amigos que em conversas informais ao longo dos anos contribuíram com idéias e opiniões que não só estão presentes neste trabalho como estarão presentes em tudo mais que eu fizer. Agradecimento especial ao Alexandre Mendonça de Barros que com suas aulas e apoio me despertou o interesse pela economia e em especial pelo estudo do desenvolvimento econômico.

A minha dívida de gratidão com o amigo Celso Toledo tornou-se impagável, agradeço por suas opiniões e sugestões que enriqueceram de maneira inestimável este trabalho.

Flaviana, muito obrigado não só por estar ao meu lado mesmo quando meu mau humor tornava impossível a aproximação de qualquer outra pessoa, ou por ouvir minhas idéias delirantes que nunca pude contar a mais ninguém, agradeço todo seu apoio, carinho e compreensão.

A minha amiga especial que sempre se acha esquecida: Viviane quando você vai perceber que eu não vou te esquecer? Obrigado por ser a pessoa para quem eu ligo no final de cada dia e por ser a amiga que você é.

A Maielli um agradecimento especial que se estende a todos os funcionários do departamento e biblioteca da economia. A FEALQ e a Capes que deram o suporte 
financeiro que possibilitou que eu me dedicasse ao estudo. Agradeço todas as pessoas não citadas mas que direta ou indiretamente contribuíram para que eu pudesse realizar esse estudo.

Por me lembrar que o desejo conquistado já foi apenas um sonho que lutamos para realizar, agradeço a Vanessa, nome fictício de alguém que apenas vi. Uma homenagem especial a João Cabral que com sua poesia me fez sonhar. 


\section{SUMÁRIO}

Página

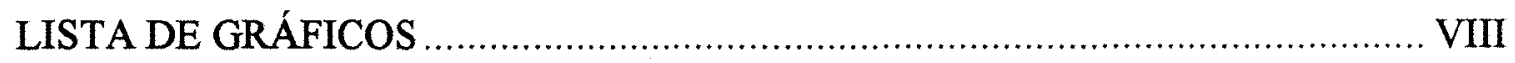

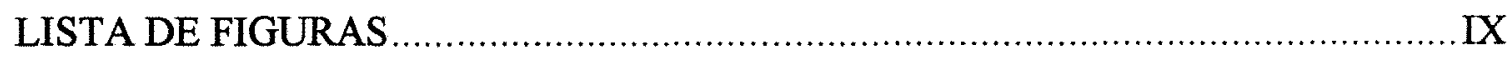

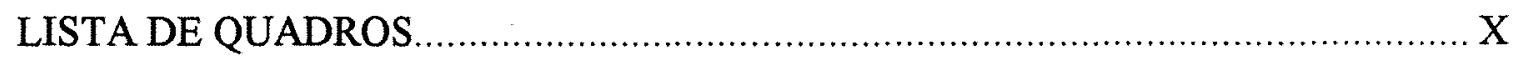

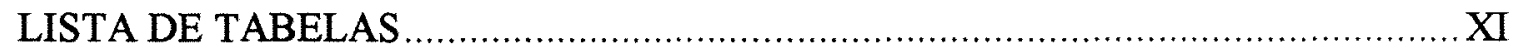

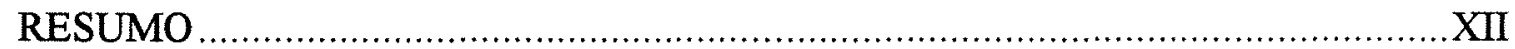

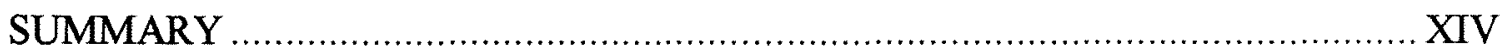

1 INTRODUÇÃO

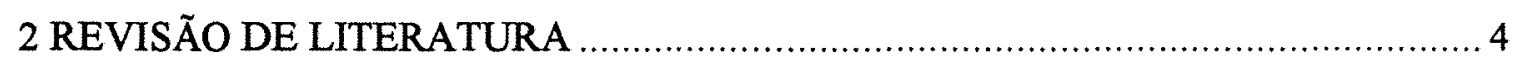

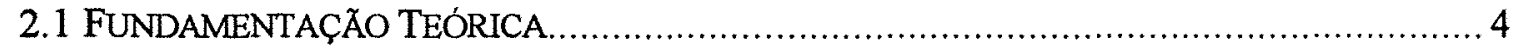

2.1.1 Determinantes do crescimento econômico e o papel do setor agricola .................. 4

2.1.2 O capital humano................................................................................................. 26

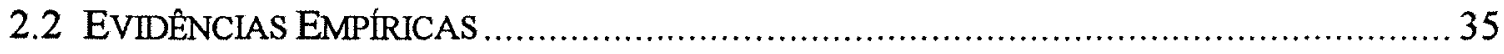

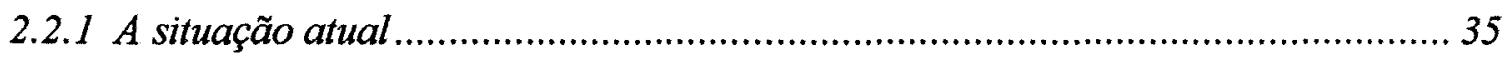

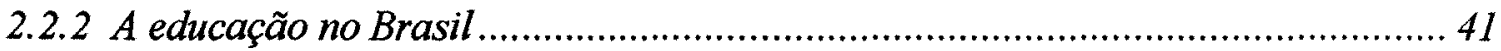

2.2.3 A Questão dos Custos da Educação no Brasil .................................................... 46

2.2.4 O problema e as hipóteses a serem testadas....................................................... 54

3 METODOLOGIA 
3.1 MODELO TEÓRICO E AS FUNÇÕES RESULTANTES ..........................................56

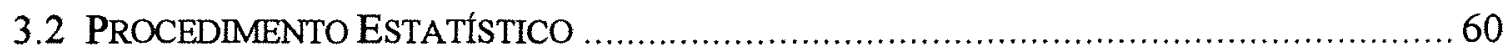

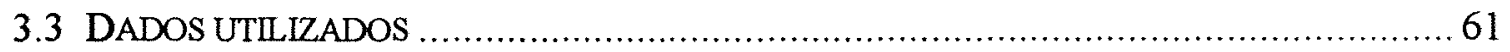

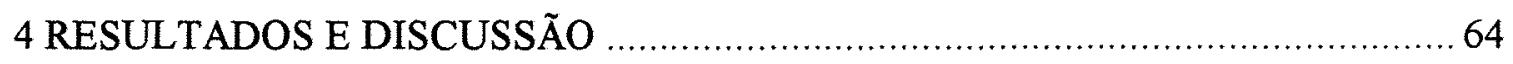

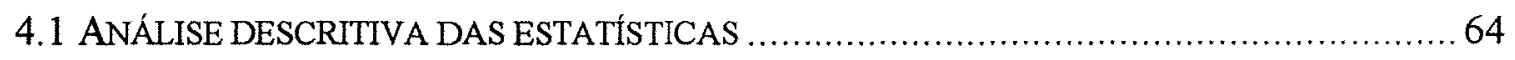

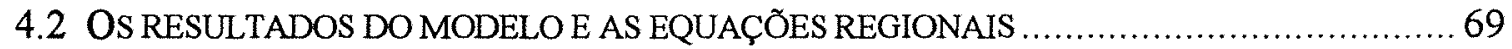

4.3 MODELO ALTERNATIVO UTLIZANDO VARIÁVEIS DUMMY ................................... 74

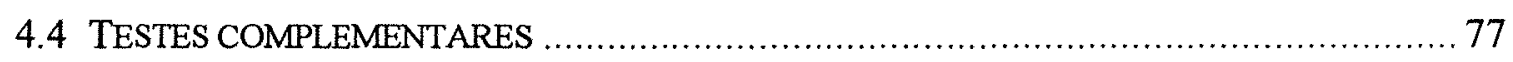

4.4.1 Verificando se o problema de heterocedasticidade foi corrigido ........................ 77

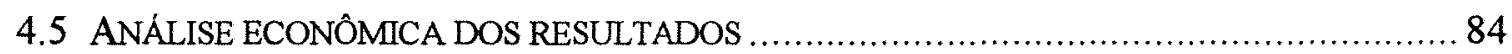

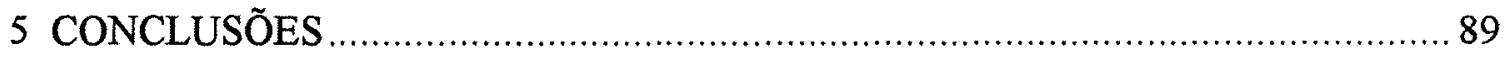

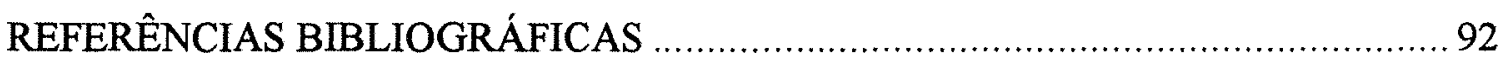




\section{LISTA DE GRÁFICOS}

Página

1 EVOLUÇÃO DO PERFIL DE OCUPAÇÃO DAS PESSOAS SEGUNDO RAMO DA ATIVIDADE

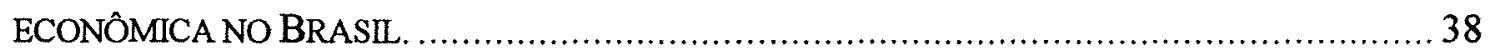

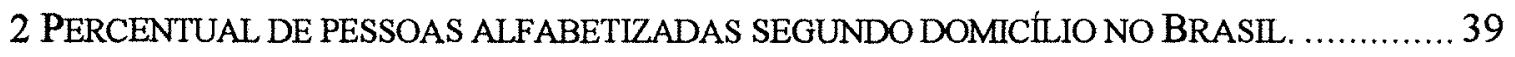

3 ANOS DE ESTUDO DA POPULAÇÃO POR SITUAÇÃO DE DOMICILIO NO BRASIL .................. 39

4 PERCENTUAL DOS MORADORES DE DOMICÍl IOS PERMANENTES, URBANOS E RURAIS, POR

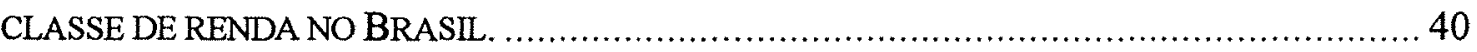

5 PERCENTUAL DE PESSOAS DAS DIFERENTES CLASSES DE RENDA SEGUNDO OS ANOS DE ESTUDO

6 MATRÍCULAS NO ENSINO FUNDAMENTAL, EDUCAÇÃO INFANTIL E CLASSES DE ALFABETIZAÇÃO POR DEPENDÊNCIA ADMINISTRATIVA NO BRASIL, 1998.

7 MATRICULAS NO ENSINO FUNDAMENTAL, EDUCAÇÃO INFANTIL E CLASSES DE ALFABETIZAÇÃO POR DEPENDÊNCIA ADMINISTRATIVA, ZONAS RURAIS NO BRASIL, EM 1998.

8 GRAU DE FORMAÇÃO DOS DOCENTES EM ATIVIDADE NO BRASIL NAS CLASSES DE ALFABETIZAÇÃO, EDUCAÇÃO INFANTIL E ENSINO REGULAR, 1998.

9 GRAU DE FORMAÇÃO DOS DOCENTES EM ATIVIDADE NO BRASIL NAS CLASSES DE ALFABETIZAÇÃO, EDUCAÇÃO INFANTIL E ENSINO REGULAR, AREAS RURAIS, 1998 .45

10 CONCLUINTES DOS CURSOS SUPERIORES POR ÁREA DE CONHECIMENTO NO BRASIL, 1995 


\section{LISTA DE FIGURAS}

Página

1 VARIÁVEIS INDEPENDENTES, ESCOLARIDADE (EDUC2) E RECURSOS FORNECIDOS PELO ESTABELECIMENTO AGROPECUÁRIO (SERV) VERSUS VARIÁVEL DEPENDENTE, VALOR ADICIONADO (VA).

2 HISTOGRAMA DA VARIÁVEIS ESCOLARIDADE (EDUC2), RECURSOS FORNECIDOS PELO ESTABELECIMENTO AGROPECUÁRIO (SERV) E VALOR ADICIONADO (VA).

3 VARIÁVEIS INDEPENDENTES, ESCOLARIDADE (EDUC2) E RECURSOS FORNECIDOS PELO ESTABELECIMENTO AGROPECUÁRIO (SERV) VERSUS VARIÁVEL DEPENDENTE, VALOR ADICIONADO (VA), NA FORMA LOGARITMICA. .68

4 HISTOGRAMA DA VARIÁVEIS ESCOLARDADE (EDUC2), RECURSOS FORNECIDOS PELO ESTABELECIMENTO AGROPECUÁRIO (SERV) E VALOR ADICIONADO (VA), NA FORMA LOGARITMICA. 69

5 DIAGRAMA DE DISPERSÃo DA AMPLITUDE E MEDIANA DA VARIÁVEL EDUC2 77

6 DIAGRAMA DE DISPERSÃO DA AMPLITUDE E MEDIANA DA VARIÁVEL SERV 78

7 DIAGRAMA DE DISPERSÃO DA AMPLITUDE E MEDIANA DA VARIÁVEL VA 78

8 DIAGRAMA DE DISPERSÃO DA AMPLITUDE E MEDIANA DA VARIÁVEL EDUC2 NA FORMA LOGARÍTMICA.

9 DIAGRAMA DE DISPERSÃo DA AMPLITUDE E MEDIANA DA VARIÁ VEL SERV NA FORMA LOGARÍTMICA. 79

10 DIAGRAMA DE DISPERSÃO DA AMPLITUDE E MEDIANA DA VARIÁVEL VA NA FORMA LOGARITMICA. 80

11 DIAGRAMA DE DISPERSÃO DA AMPLITUDE E MEDIANA DA SÉRIE DOS RESIDUOS. 82

12 TESTE DOS RESÍDUOS RECURSIVOS 83

13 TESTE DOS COEFICIENTES RECURSIVOS 84 


\section{LISTA DE QUADROS}

1 PERCENTUAL DA POPULAÇÃo ECONOMICAMENTE ATIVA EMPREGADA NO SETOR AGRÍCOLA

2 RENDIMENTO MÉDIO MENSAL REAL DOS CHEFES DE DOMICLIIO RURAL E URBANO (EM REAIS) 37

3 PERCENTUAL DA POPULAÇÃo QUE VIVE EM ZONAS RURAIS

4 PESSOAS OCUPADAS DE 10 ANOS OU MAIS DE DADE POR RAMO DE ATIVIDADE ECONÔMICA DA OCUPAÇÃO PRINCIPAL, EM PERCENTAGEM. 38

5 GASTO ANUAL MÉDIO POR ALUNO NO ENSINO FUNDAMENTAL POR REGIÃO E ESTADOS DO BRASIL: 1995 (EM R \$ 1,00)

6 GASTO ANUAL MÉDIO POR ALUNO NO ENSINO MÉDIO POR REGIÃO E ESTADOS DO BRASIL: 1995 (EM R\$ 1,00). 49

7 GASTO ANUAL MÉDIO POR ALUNO NO ENSINO SUPERIOR POR REGIÃO E ESTADOS DO

BRASIL: 1995 (EM R\$ 1,00)

8 GASTO PÚBLICO CONSOLIDADO EM EDUCAÇÃO E O PIB, PELA METODOLOGIA IPEA AGREGANDO GASTOS DE OUTRAS ÁREAS (GASTO EM EDUCAÇÃO EXPANDIDO): BRASIL, 1995

9 PARTICIPAÇÃO DOS GASTOS DOS NIVEIS E AÇÕES NA ÁREA DE EDUCAÇÃO POR ESFERA DE GOVERNO: 1995 (EM R\$ MIL NOMINAIS) 


\section{LISTA DE TABELAS}

Página

1 ESTIMATIVAS DOS PARÂMETROS E DESVIOS-PADRÃO DAS FUNÇÕES VALOR ADICIONADO E DAS REGRESSÕES AUXILIARES NA EQUAÇÃO BRASL E NAS EQUAÇÕES REGIONAIS. .... 70 2 ESTIMATIVAS DOS PARÂMETROS E DESVIOS-PADRÃO DAS FUNÇÕES VALOR ADICIONADO PER CAPITA E DAS REGRESSÃO AUXILIARES NA EQUAÇÃO BRASIL E NAS EQUAÇÕES REGIONAIS.

3 ESTIMATIVA DOS PARÂMETROS E DESVIOS-PADRÃO DA FUNÇÃO VALOR ADICIONADOE DA REGRESSÃO AUXILIAR NO MODELO COM VARIÁVEIS DUMMY. .75

4 ESTIMATIVA DOS PARÂMETROS E DESVIOS-PADRÃO DA FUNÇÃO VALOR ADICIONADO PER CAPITA E DA REGRESSÃO AUXILIAR NO MODELO COM VARIÁVEIS DUMMY. 76

5 ESTIMATIVA DOS PARÂMETROS E DESVIOS-PADRÃO DA FUNÇÃO AMPLITUDE PARA AS SÉRIES DA VARIÁVEIS EDUC2, SERV E VA COM E SEM A APLICAÇÃO DO LOGARITMO. 81 


\title{
RELAÇÕES ECONÔMICAS ENTRE EDUCAÇÃO E PRODUTO SOCIAL DA AGRICULTURA
}

\author{
Autor: ERALDO GENIN FIORE \\ Orientador. Prof. PAULO FERNANDO CIDADE DE ARAÚJO
}

\section{RESUMO}

A agricultura desempenha importante papel no desenvolvimento econômico. A indústria quando incipiente depende, em grande medida, da capacidade do setor agrícola gerar excedentes para financiar seu crescimento. Quando o país se desenvolve, a importância da agricultura diminui. $\mathrm{O}$ setor industrial $\mathrm{e}$, posteriormente, o setor de serviços passam a gerar maior parcela da renda total e empregar maior número de trabalhadores. Em muitos países em desenvolvimento, o setor não-agrícola é incapaz de absorver toda mão-de-obra que o desenvolvimento tecnológico libera da agricultura. No Brasil, isso se reflete na grande parcela da população economicamente ativa que permanece ocupada em atividades agrícolas sem remuneração ou que permitem apenas a sobrevivência. No mercado de trabalho do setor não-agrícola, a exigência por profissionais qualificados dificulta que esses trabalhadores encontrem emprego. Essa parcela da mão-de-obra normalmente tem baixa escolaridade e seu acesso a educação é complicado. Os maiores problemas na infra-estrutura educacional e mesmo na qualidade de docentes se encontram nas áreas rurais. Esse estudo procura mostrar que o investimento na educação pode contribuir positivamente para o desenvolvimento da 
agricultura ao possibilitar aumento na produção. Para testar essa hipótese, a importância da educação como insumo que influencia a produção agrícola foi medida utilizando modelo econométrico. $\mathrm{O}$ modelo escolhido permite captar tanto o efeito direto como o efeito indireto da educação. A segunda hipótese testada sugere que o efeito indireto, no geral, é maior que o efeito direto. $O$ efeito indireto deve ser maior nas áreas que praticam agricultura moderna. Nas áreas de agricultura tradicional, com tecnologia estagnada, pouco espaço deve haver para ganhos na habilidade alocativa. Nesse caso, o efeito direto deve ser mais importante que o efeito indireto. $O$ efeito total da educação sobre a produção deve ser maior nas áreas modernas quando em comparação com áreas de agricultura tradicional. Esta é a terceira hipótese testada no estudo. Os resultados da análise econométrica sugerem que a educação possibilita aumento significativo do produto adicionado na agricultura. A consistência do modelo foi testada indicando que os resultados são bastante confiáveis. $\mathrm{O}$ modelo mostrou, ainda, que o efeito total da educação sobre o produto adicionado agrícola é maior nas áreas de agricultura moderna, sendo o efeito indireto mais importante nessas regiões. Nas áreas tradicionais, o efeito total é menor e o efeito direto mais relevante. Os ganhos alocativos nas áreas tradicionais são pequenos. Esse resultado é importante pois indica que o aumento da educação pode ampliar as vantagens econômicas das áreas de agricultura moderna sobre as tradicionais. $\mathrm{O}$ menor retorno aos investimentos em educação ocorre justamente nas áreas onde é reduzida a capacidade de financiamento dos estados e municípios, sobretudo nas regiões Norte e Nordeste. Como os grandes problemas de pobreza e baixa escolaridade ocorrem principalmente nestas regiões, especial atenção deve ser voltada para esta população. 


\title{
ECONOMIC RELATIONS BETWEEN EDUCATION AND SOCIAL PRODUCT OF AGRICULTURE
}

\author{
Author: ERALDO GENIN FIORE \\ Adviser: Prof. PAULO FERNANDO CIDADE DE ARAÚJO
}

\section{SUMMARY}

The agriculture plays important role in economic development. The rising industry depends, in large way, from agriculture sector capacity to produce excess to support your growth. When the country develop reduce the agriculture importance. The industry and, after, services get to produce more income and employment. In many development countries, the non-agriculture sector is unable to absorb all labour that technological development release from agriculture. In Brazil, that reflect in the large share of the economically active population that stay engage in agricultural activity without remuneration or working just to survive. In the non agricultural sector work market, the qualify professionals requirement make difficult that this workers find job. This share of labour have low school and your access to education is complicate. In the rural areas are the great problems in the education structure and docents quality. This study try to show that the education investment can help with the agriculture development rising the production. To test this hypothesis, the role of education in agricultural production was measure making use of econometric model. The chosen model allow to catch both education effects, the direct effect and the indirect effect. The second hypothesis says that indirect effect, normally, is higher than direct effect. The 
indirect effect should be higher in modern agriculture areas. In the traditional agriculture areas, with stagnant technology, the gains from alocative ability should be small, in this case, the direct effect should be more important than indirect effect. The total education effect in production should be higher in modern areas. This is the third hypothesis to be test. The econometric analysis suggest the education possibility meaningfully increase in agriculture output. The model's consistency was test and the results are trustful. The model shows, moreover, that the total education effect is higher in modern agriculture. In this regions, the indirect effect is more important. In the traditional agriculture, the total effect is small and the direct effect is more relevant. The allocative gains in traditional areas are small. This result denote that more education widen the modern agriculture economic advantage. The small return to investment in education occur in traditional agriculture where the financial capacity of states and municipal districts is reduced. Because the major problems with poverty and low schooling occur in this regions, special attention should be concede to this population. 


\section{INTRODUÇÃO}

"... afundando, nas areias movedigas do lixo da capital da Índia, as bistórias que ouvi foram de migragóes envolvendo pessoas do país todo".

Gita Mebta

O movimento migratório dos camponeses em direção às grandes cidades, em busca do emprego no setor não agrícola, é um fenômeno mundial e importante dentro do processo de desenvolvimento econômico. Quando ainda incipiente, o setor de manufaturados necessita da mão-de-obra da agricultura, assim como do excedente financeiro que esta possa gerar, para viabilizar o seu crescimento.

A demanda por trabalhadores por parte do setor não agrícola representa perda para a agricultura de dois importantes fatores, trabalho e capital humano. Trabalho representado na população que migra em direção as cidades. Capital humano, pois os trabalhadores que primeiro saem da agricultura são aqueles mais bem treinados, com maior capacidade empresarial e com menor aversão ao risco.

Com menos trabalhadores, a produtividade da mão-de-obra na agricultura aumenta, o que é viabilizado quando a indústria é capaz de ofertar ao agricultor, a preços declinantes, os chamados insumos modernos. A substituição de trabalhadores por insumos deve continuar propiciando o aumento da produtividade agrícola. $\mathrm{O}$ que só ocorrerá se o setor não agrícola crescer suficientemente rápido para absorver os trabalhadores que vão sendo substituídos neste processo. 
Esta dinâmica que surge entre os setores agrícola e não agrícola tem importância central na transição de uma economia predominantemente agrária para uma economia moderna, caminho necessário em qualquer país que busca desenvolvimento econômico. Desta forma, a importância relativa da agricultura diminui à medida que o país se desenvolve, bem como diminui a população que retira o seu sustento de atividades essencialmente agrícolas. Não significando, contudo, que o setor agrícola deixa de ter importância econômica. Apenas alteram-se quantitativa e qualitativamente os papéis que a agricultura deve desempenhar para o crescimento da economia.

A modernização do setor não agrícola, e da própria agricultura, por seu turno, muda o padrão de demanda por trabalhadores, exigindo menos pessoas e maior qualificação. Desta forma, o crescimento da economia de alguns países esbarra em um paradoxo, sobra mão-de-obra, mas falta capital humano.

A educação, a saúde, e outros conceitos diretamente relacionados com a qualidade da mão-de-obra, neste momento, tornam-se o fator limitante ao crescimento do produto. Normalmente, é no setor agrícola que se concentra a mão-de-obra menos produtiva e, provavelmente, menos qualificada. Em algum momento, no entanto, o aumento da população redundante que se abriga na agricultura deve esgotar a capacidade deste setor manter estas pessoas ocupadas, ainda que com baixa produtividade. $\mathrm{O}$ quadro resultante será de conflitos sociais no campo e pessoas vivendo em condiçðes subumanas nos arredores dos grandes centros.

Aumentar o estoque de capital humano desta população, principalmente melhorando seu nível educacional, pode ser a resposta para este problema. Mesmo sendo elevado o número de pessoas com produtividade baixa que trabalham na agricultura, o aumento da educação deve aumentar o produto agrícola, contribuindo positivamente para o desenvolvimento do setor.

A resposta ao aumento da educação não ocorre necessariamente de forma homogênea entre as diferentes regiões do país. Há razões teóricas para acreditar que o grau de tecnologia empregado na agricultura de cada região pode influenciar nessa 
resposta. O desenvolvimento agricola propiciado pelo aumento da educação ocorreria, então, de forma desigual. Conhecer melhor a natureza desse processo é importante para entender o desenvolvimento da agricultura.

Fundamentalmente, a pergunta que este trabalho procura responder é: qual o papel que a educação desempenha no processo de desenvolvimento e modernização da agricultura ? Para entender e responder tal questão três pontos devem ser abordados: análise quantitativa da educação como fator que influencia a produção na agricultura, procurando detectar as diferenças regionais; análise qualitativa da situação educacional no país e sua importância no mercado de trabalho; e, análise da capacidade de financiamento da educação pelas diferentes esferas de governo. Com esse objetivo, optou-se por conduzir a discussão situando teoricamente o problema abordado para, posteriormente, realizar uma análise empírica.

O trabalho segue dividido em capítulos, da seguinte forma: o capítulo 2 Revisão de literatura, subdividido em 2.1 - Fundamentação Teórica e 2.2 - Evidências Empíricas, discute teoricamente o problema. Abordando essencialmente as fontes de crescimento econômico, a importância do setor agrícola e da sua dinâmica com o setor não agrícola para o desenvolvimento econômico; o capital humano e sua importância para o desenvolvimento e, mais especificamente, os efeitos da melhor educação na economia e na agricultura. $O$ item Evidências Empíricas, procura retratar a situação educacional brasileira, enfatizando as condições presentes em zonas rurais. Este capítulo aborda, também, a importância da educação no mercado de trabalho e a questão dos custos da educação e da capacidade de financiamento do Estado.

O capítulo 3 - Metodologia, apresenta o modelo a ser utilizado para captar o impacto da educação na produção agrícola. Discute a agregação e a qualidade dos dados. O capítulo 4 - Resultados e Discussão, traz a análise dos resultados empíricos encontrados e discute algumas características econométricas do modelo. O capítulo 5 Conclusões, encerra o trabalho com as considerações finais. 


\section{REVISÃO DE LITERATURA}

\subsection{Fundamentação Teórica}

\subsubsection{Determinantes do crescimento econômico e o papel do setor agrícola}

"Most of the people in the world are poor, so if we knew the economics of being poor, we would know much of the economics that really matters. Most of the world's poor people earn their living from agriculture, so if we knew the economics of agriculture, we would know much of the economics of being poor."

T.W. Scbultz, $1979^{\prime}$.

A agricultura constitui o principal setor da economia em países nos estágios iniciais de desenvolvimento, concentrando a maior parte da população e do produto gerado. No processo de desenvolvimento econômico, a tendência natural é a agricultura perder importância relativa na economia. Nos países desenvolvidos, a maior parcela da população retira seu sustento de atividades essencialmente não agrícolas.

Contudo, ainda hoje, aproximadamente 4,7 bilhões de pessoas vivem em países que apresentam Índice de Desenvolvimento Humano $(\mathrm{DH})$ de baixo a médio e apenas 1 bilhão de pessoas vivem em países que apresentam $\mathrm{IDH}$ alto ${ }^{2}$. Muitos países ainda

\footnotetext{
${ }^{1}$ SCHULTZ, T.W. The economics os being poor. Nobel Lecture. Stockholm, Sweden: Nobel Foundation, Dez. 1979.

${ }^{2}$ O Índice de Desenvolvimento Humano (IDH) é um indicador anual, elaborado com dados apurados com dois anos de defasagem, que busca captar variáveis indicativas da qualidade de vida da população. A fonte utilizada foi o "Relatório do Desenvolvimento Humano" da PNUD/ONU (Organização das Naç̃̃es Unidas).
} 
dependem diretamente do setor agrícola e $54 \%$ da população mundial ${ }^{3}$ vivem em áreas rurais. Nos países de baixa renda, $31 \%$ do produto são gerados na agricultura, que é responsável por $72 \%$ do emprego 4 .

A situação mundial hoje ainda faz verdadeiras as palavras em epígrafe do professor Schultz. O esforço na busca do desenvolvimento econômico requer maior conhecimento sobre o setor agrícola e sua inter-relação com os demais setores da economia. Na literatura, estudar crescimento econômico voltou a ganhar importância, principalmente, depois do trabalho de Romer (1986) e com as teorias de crescimento endógeno.

Estas novas teorias utilizam muitos dos avanços da teoria microeconômica, baseando-se principalmente em modelos de equilíbrio em competição imperfeita. Esta, no entanto, não parece ser a realidade do setor agrícola, que na maioria dos países, incluindo o Brasil, apresenta um modelo que muito se aproxima da competição perfeita. Assim, para os objetivos desse estudo, considera-se fundamental rever e enfatizar os modelos mais "antigos", desenvolvidos principalmente nas décadas de 50 e 60.

Os economistas clássicos, como Smith, Ricardo, Malthus e Marx, já se preocupavam com os fatores determinantes do crescimento econômico. Vivendo em sociedades predominantemente agrárias, a relação entre o setor agrícola e o crescimento da economia teve forte influência no pensamento econômico da época. $O$ crescimento do produto era visto diretamente dependente do volume de fatores empregados na produção, como, terra, capital e mão-de-obra.

$\mathrm{Na}$ visão de Ricardo, o produto da manufatura pode aumentar além da maior utilização dos fatores, por aquilo que hoje é chamado desenvolvimento tecnológico. Ricardo acreditava que, no setor agrícola, o desenvolvimento tecnológico pode ocorrer, mas em ritmo muito mais lento. Assim, o crescimento populacional obriga a utilização de maior volume de recursos na agricultura, notadamente, terra.

\footnotetext{
${ }^{3}$ Fonte: Food and Agriculture Organization of the United Nations (FAO). Dados referentes ao ano de 1995.

${ }^{4}$ Fonte: Stern, 1994.
} 
O aumento populacional demanda um incremento na produção agrícola, que só é possível expandindo a área de cultivo em direção a terras menos férteis e, portanto, menos produtivas. Logo, a produção cresce mas a taxas decrescentes. Como o setor agrícola constituía o principal setor da economia na época, o progresso técnico da manufatura não seria capaz de compensar os rendimentos decrescentes da agricultura. $O$ crescimento de toda economia tornar-se-ia limitado pelo setor agrícola.

Ricardo, assim como muitos pensadores da época, relaciona o crescimento populacional com as variações na renda. No modelo ricardiano, a economia cresce acumulando capital. Com isso, a demanda por mão-de-obra aumenta, aumentando também os salários. Quando os salários tornam-se mais altos que o salário de subsistência a população cresce. Mas, com o crescimento populacional, os rendimentos tornam-se decrescentes e os lucros advindos das inversões de capital diminuem. Com menor lucro o incentivo a investir diminui, diminuem a acumulação de capital e a taxa de crescimento populacional. Desta forma, o crescimento da produção agrícola e manufatureira cessa e a economia entra em estagnação, a não ser que ocorra desenvolvimento tecnológico também na agricultura.

Para Ricardo, portanto, a agricultura representa o setor que limita o crescimento da economia, caracterizado, principalmente, pela presença de retornos marginais decrescentes e pouco ou nenhum progresso tecnológico. No modelo desenvolvido por Lewis, em $1954^{5}$ (ver, por exemplo, Stern, 1994), a distinção é entre dois setores, avançado e tradicional, o que não necessariamente eqüivale a dizer agricultura e indústria. Isso porque Lewis considera que parte da indústria e dos serviços podem caracterizar-se como tradicional, assim como parte do setor agrícola pode ter características de um setor avançado.

A distinção entre avançado e tradicional para Lewis, baseia-se em três aspectos, quais sejam, institucional, de comportamento e tecnológico. No setor avançado o produto e o emprego são determinados por decisões de firmas que maximizam lucro, e a

${ }^{5}$ LEWIS, W.A. Economic Development with Unlimited Supplies of Labour. Manchester School, 22: p. 139-91. 1954. 
renda é dividida entre lucro e salários. Lucro, este, que dá origem a poupança que será investida no próprio setor avançado. No setor tradicional o produto é exógeno ao modelo e o mercado de trabalho não está em equilibrio competitivo, sendo o salário deste setor fixado institucionalmente.

Note tratar-se de um modelo clássico, em que o mercado de trabalho não é perfeito. Portanto, não há igualdade no valor do produto marginal entre os setores. Isso significa que o salário fixado para o setor tradicional é definido pelo produto marginal no setor avançado, enquanto no setor tradicional o produto marginal do trabalho é zero ou negativo. Ou seja, parte da mão-de-obra do setor tradicional pode ser deslocada para o setor avançado sem reduzir o produto gerado pelo setor tradicional, enquanto existir excedente de mão-de-obra neste setor.

A possibilidade do setor avançado utilizar esta mão-de-obra redundante, que a princípio não contribui para gerar produto no setor tradicional, é uma importante fonte de crescimento econômico. Deslocar esta parcela da população gera crescimento, pois sem redução do produto no setor tradicional, há ganhos de produção no setor avançado. Esta migração populacional, em direção ao setor avançado, ocorre até não haver excesso de mão-de-obra no setor tradicional.

Esta constitui, na visão de Lewis, a mais importante contribuição do setor tradicional para o crescimento da economia. A transferência de capital e outros recursos do setor tradicional para o avançado é minimizada neste modelo. Por pressuposição apenas o setor avançado é capaz de gerar poupança, assim, o seu crescimento passa a depender da sua própria capacidade em gerar excedentes.

Mesmo gerando excedentes no setor moderno, a economia no inicio do desenvolvimento apresenta taxas muito baixas de poupança, inviabilizando inversões de alta rentabilidade capazes de sustentar o crescimento deste setor. Lewis explica que o país aumenta a propensão marginal a poupar, não por mudanças de hábitos da população do setor tradicional, mas sim pelo próprio surgimento de empresários capitalistas, com 
nova mentalidade empreendedora, que concentrará em seu poder grande proporção dos excedentes gerados, reinvestindo-os no próprio setor moderno.

Formalizando o modelo ${ }^{6}$, considere que o produto do setor avançado $(\mathrm{Y})$ seja função do capital (K) e do emprego $(L)$ no setor avançado, ou seja, $F(K, L)$. A função de maximização dos lucros no setor avançado, considerando o salário fixo, implica

$F_{L}(K, L)=w$

Note que w é o salário fixo e o subscrito L denota a importância do produto marginal. A poupança, como já ressaltado anteriormente, é igual ao lucro do setor avançado (П). Portanto, o investimento depende apenas do setor avançado. Desconsiderando a depreciação do capital,

$(K t-K t-1)=F(K, L)-w L$

Como w é, por pressuposição, exógeno ao modelo, assumindo que $\mathrm{F}$ apresenta retornos constantes a escala, percebe-se facilmente que a proporção capital-trabalho em (1), mantém-se constante ao longo do tempo e igual ao salário w.

Como ressaltado anteriormente, a taxa de poupança, neste modelo, depende do lucro obtido no setor avançado que, por sua vez, é igual a taxa de crescimento do capital. Com retornos constantes a escala, a taxa de lucro será igual ao produto marginal do capital Fk $(K, L)$ (lembre que, pelo teorema de Euler, $\left.F=K F_{k}+L F_{L}\right)$. Como a proporção capital-trabalho é constante, $F_{k}$ será fixo ao longo do tempo. A proporção dos fatores permanece constante ao longo do tempo, logo, produto, capital e trabalho, crescem à mesma taxa, que deve ser igual a taxa de lucro, ou seja, consistente com o salário exógeno $\mathrm{w}$.

Porém, a taxa de crescimento total da economia não depende apenas do produto gerado pelo setor avançado. $O$ produto total na economia $(X)$ é, na verdade, a soma do produto do setor avançado $(\mathrm{Y})$, com o produto gerado no setor tradicional $(\mathrm{T})$. A taxa de

\footnotetext{
${ }^{6}$ A formalização do modelo de Lewis é adaptada de Stern (1994).
} 
poupança da economia como um todo e, portanto, a taxa de crescimento de toda economia, será dada por

$\mathrm{S} / \mathrm{X}=\Pi / \mathrm{X}=\alpha \Pi / \mathrm{Y}$

$\left(\mathrm{Xt}_{\mathrm{t}}-\mathrm{Xt}-1\right) / \mathrm{Xt}=\left[\alpha(\mathrm{Yt}-\mathrm{Yt}-1) / \mathrm{Yt}_{\mathrm{t}}\right]+[(1-\alpha)(\mathrm{Tt}-\mathrm{Tt}-1) / \mathrm{T} \mathrm{t}]$

Nessas equações $S$ denota a poupança e $\alpha$ a participação do setor avançado no produto total. Assim, quando o produto do setor avançado crescer mais rapidamente que o produto do setor tradicional, $\alpha$ irá crescer ao longo do tempo, assim como a poupança total da economia.

Sabendo que o produto marginal do trabalho no setor tradicional é zero, então o produto $\mathrm{T}$ mantém-se constante. Desta forma, na visão de Lewis, o crescimento de toda economia depende do setor avançado. Note, portanto, a importância que o aumento na taxa de poupança exerce sobre o crescimento econômico neste modelo.

Acumular capital é o alicerce de grande parte dos modelos de crescimento. No modelo de Harrod e Domar a necessidade de acumular capital constitui o ponto central para a economia crescer. Este modelo foi importante referencial teórico tanto para formuladores de política pública da época, quanto para estudiosos do desenvolvimento econômico, influenciando até mesmo os modelos endógenos de crescimento.

Harrod, em1939 ${ }^{7}$, coloca o equilíbrio Keynesiano poupança - investimento dentro de um contexto dinâmico. A partir deste ponto se desenvolve o modelo de Harrod e Domar, que apesar de trabalharem isoladamente, formularam modelos muito semelhantes nas questões essenciais.

Chamando a poupança de $\mathrm{S}$, o investimento será, como implicação do equilibrio poupança-investimento, a taxa de crescimento do estoque de capital (K), ou seja,

$\mathrm{K}=\mathrm{S}$

\footnotetext{
${ }^{7}$ A formalização do modelo de Harrod e Domar é adaptada de Stern (1991) e de Araújo \& Schuh (1991).
} 
Sabendo que $\mathrm{S}$ é uma fração do produto, a taxa de poupança (s), que é a propensão marginal a poupar da economia, será dada por $\mathrm{s}=\mathrm{S} / \mathrm{Y}$. Considere que a relação capitalproduto da economia seja dada por $\mathrm{v}=\mathrm{K} / \mathrm{Y}$. Dividindo a equação (5) por $\mathrm{K}$, tem-se:

$(\mathrm{Kt}-\mathrm{Kt}-1) / \mathrm{Kt}=\mathrm{s} / \mathrm{v}$

Dividindo a expressão (6) por Y, chega-se a condição de Harrod e Domar,

$(\mathrm{Yt}-\mathrm{Yt}-1) / \mathrm{Yt}=\mathrm{s} / v$

Onde, $v=(\mathrm{Kt}-\mathrm{Kt}-1) /\left(\mathrm{Yt}_{\mathrm{t}}-\mathrm{Yt}-1\right)$, ou seja, o incremento na relação capital - produto.

Note, então, que a taxa de crescimento que mantém a economia em pleno emprego (g), ou seja, $\left(Y_{t}-Y_{t-1}\right) / Y t$, é :

$\mathrm{g}=\mathrm{s} / \mathrm{K}$

Este modelo visa manter uma situação de pleno emprego, quando oferta e demanda estão em equilíbrio. Neste sentido, a manutenção do pleno emprego ao longo do tempo depende, como ressaltam Araújo \& Schuh (1991), "da taxa de crescimento econômico considerada suficiente para, simultaneamente, compensar a poupança e utilizar o estoque de capital disponível".

Note que, segundo este modelo, o investimento desempenha um papel primordial como fonte de crescimento econômico, já que dele depende o aumento da capacidade produtiva da economia, bem como será o investimento o gerador de renda. Portanto, políticas que promovam o aumento da propensão marginal a poupar (s), ou que reduzam a relação capital-produto (v) poderão, sob a ótica deste modelo, aumentar a taxa de crescimento da economia.

A noção que acumular capital é uma importante fonte de crescimento econômico vai ganhando sedimentação teórica. No entanto, para países no início do processo de desenvolvimento, que apresentam baixa propensão marginal a poupar, acumular capital não é uma tarefa trivial. O modelo proposto por Britton ${ }^{8}$, em 1955, que na verdade é um

\footnotetext{
${ }^{8}$ A formalização do modelo de Britton (1955) é adaptada de Araújo \& Schuh (1991)
} 
refinamento ao modelo de Harrod e Domar, traz uma possível resposta a questão de como acumular capital nas economias pouco desenvolvidas. Britton "abre" a economia, que no modelo de Harrod e Domar era "fechada" por pressuposição, incorporando à equação de crescimento econômico, recursos provenientes das transações com o exterior.

Considere $\mathrm{M}$ como o valor das importações de capital, $\mathrm{X}$ o valor das exportações de capital e $\mathrm{Y}$ a renda nacional. Considerando $\mathrm{b}=(\mathrm{M}-\mathrm{X}) / \mathrm{Y}$, Britton mostra que o país pode utilizar poupança externa, via empréstimos ou capital de risco, como uma importante fonte de investimento líquido na economia. Em termos algébricos, a equação de Britton introduz à equação de crescimento econômico a relação b/K, resultando que:

$\mathrm{g}=(\mathrm{s} / \mathrm{K})+(\mathrm{b} / \mathrm{K})$

A idéia é o país poder utilizar poupança externa para fazer crescer a economia, tornando-se menos dependente da sua própria poupança, mas, necessitando para isso gerar divisas. Na visão de Lewis, a necessidade inicial do setor avançado está, principalmente, em melhoramentos na infra-estrutura, o que exige muita mão-de-obra e pouco capital. No entanto, Lewis não explica como as fábricas poderão comprar equipamentos sem um excedente exportável.

Gerar um excedente exportável torna-se, portanto, um desafio para o crescimento econômico. Com uma indústria incipiente que dificilmente será capaz de gerar excedentes exportáveis, esta tarefa recai sobre o setor agrícola. Apenas transferir mãode-obra para o setor avançado, que na visão de Lewis, é a necessária contribuição do setor tradicional, não parece ser o bastante para possibilitar o desenvolvimento da economia.

No entanto, gerar excedentes para exportação exige que o setor agrícola cresça, 0 que quase sempre não ocorre na visão de Lewis. Nas palavras de Fei \& Ranis (1975), “a estagnação nas técnicas agrícolas representa um ponto de estrangulamento que até o presente momento poucos países subdesenvolvidos conseguiram superar". A 
preocupação de Fei e Ranis não era apenas com o excedente exportável, mas essencialmente com o mercado para os produtos gerados na indústria nascente.

Para estes autores, as pessoas que deixam a agricultura em direção a indústria, movimento semelhante ao apresentado por Lewis, tendem a consumir os mesmos produtos que consumiam anteriormente nas zonas rurais, ou seja, produtos agrícolas. Isso ocorre tanto por uma questão de hábitos de consumo, como porque o salário recebido por estes trabalhadores difere pouco daquele que recebiam na agricultura. Eles não dispõem de renda suficiente para mudar seus hábitos de consumo.

Analisando desta forma, a indústria em desenvolvimento não teria mercado para vender seus produtos. Neste ponto, a dinâmica existente entre os setores agrícola e industrial torna-se fundamental ao desenvolvimento econômico. No modelo de Fei e Ranis, a agricultura assume o importante papel de ser mercado dos produtos industrializados, mas para que isso ocorra são necessárias mudanças estruturais na agricultura.

Vale a pena fazer aqui uma distinção importante entre o modelo de Lewis e o de Fei e Ranis. Para Lewis, a agricultura se organiza em pequenas propriedades onde o trabalho do proprietário e sua família constitui a principal fonte de mão-de-obra. Fei e Ranis consideram que a mão-de-obra é assalariada e contratada pelo proprietário. Esta diferenciação é importante porque quando o setor agrícola vende seu produto para a população urbana gera um excedente, que será apropriado pela maioria dos trabalhadores no modelo de Lewis e por um menor número de proprietários no modelo de Fei e Ranis.

A existência de um excedente na mão de poucos proprietários é, para Fei e Ranis, a condição necessária para dinamizar o setor agrícola. Estes empresários rurais podem investir sua poupança em atividades industriais, dando origem a uma indústria conectada ao setor agrícola. Esta inter-relação entre indústria e agricultura permite que os empresários detectem as possibilidades de ganho nos dois setores, o que torna possível o crescimento a ambos. 
Este padrão de crescimento é importante ponto do modelo pois a agricultura precisa se tornar mercado para o produto industrial. Mais do que isso, Fei e Ranis acreditam que "o aumento no fluxo de inovações está diretamente ligado à percep̧̧ão de oportunidades por parte das unidades de decisão na agricultura, seja para adquirir propriedade sobre o estoque de capital do setor industrial ou para adquirir bens de consumo produzidos por este setor".

A hipótese de existir mão-de-obra no setor tradicional com produtividade marginal nula é criticada por diversos autores. Jorgenson (1975), oferece uma longa discussão sobre o assunto. Este autor ressalta uma característica importante do emprego na agricultura, qual seja, "parte considerável da força de trabalho agrícola pode ficar desempregada durante um certo período do ano sem ser redundante". Isso ocorre devido à natureza sazonal do trabalho na agricultura.

O próprio Lewis mostra que o desemprego disfarçado não é uma característica necessariamente presente em todos os países em desenvolvimento. Estudos empíricos que levam em consideração a natureza sazonal do emprego agrícola tendem a não confirmar a hipótese de Lewis e Fei e Ranis, como mostra o trabalho de Jorgenson.

A existência de desemprego disfarçado implica, também, que no inicio do processo de desenvolvimento a força de trabalho agrícola deve cair, em termos absolutos. Padrão que, no entanto, não parece estar em consonância com as evidências históricas da maioria dos países. Como ressalta Jorgenson, o padrão japonês, país utilizado por Fei e Ranis no seu modelo, e em outros países da Europa, "o período precedente à predominância relativa da força de trabalho não agrícola foi caracterizado por uma força de trabalho agrícola estável, aumentando ou declinando a taxas bastante moderadas, durante o período inicial de industrialização. Este padrão é inconsistente com a hipótese de trabalho redundante ou de desemprego disfarçado".

A questão da existência ou não de desemprego disfarçado é a principal diferença entre modelos clássicos e neoclássicos de economias dualistas. $\mathrm{O}$ modelo desenvolvido por Jorgenson considera que, mesmo no setor tradicional, os salários são definidos no 
mercado competitivo inclusive nos estágios iniciais de desenvolvimento. Isto implica, como ressalta Schultz (1964), que a transferência de mão-de-obra da agricultura para indústria não se faz sem sacrifício de produção agrícola.

Jorgenson (1975), analisando a experiência japonesa, sugere que a taxa de crescimento declina e a razão capital-produto aumenta com o tempo, contrariando o modelo clássico que prediz um aumento na taxa de crescimento da economia como um todo e uma relação capital produto constante. $O$ resultado do modelo de Jorgenson se aproxima, no longo-prazo, de modelos neoclássicos de um setor, como o apresentado por Solow.

Em 1956, Solow ${ }^{9}$ assume que a produção da economia é uma função do estoque de capital e do trabalho, função essa que, por pressuposição, apresenta retornos constantes à escala. $\mathrm{O}$ crescimento do produto por trabalhador aumenta com o maior emprego de capital por trabalhador, mas sujeito a lei dos rendimentos marginais decrescentes. $\mathrm{O}$ crescimento do produto depende dos investimentos, que como no modelo da Harrod e Domar, dependem da taxa de poupança da economia. Novamente, o crescimento da economia no curto-prazo é diretamente dependente da acumulação de capital.

No entanto, como o capital apresenta produtividade marginal decrescente, a economia tende a um ponto em que, a um determinado nível de estoque de capital, o investimento será suficiente apenas para pagar a parcela do capital depreciado. Neste ponto, conhecido como "steady-state", o crescimento do produto será igual a taxa de crescimento populacional e o produto per capita torna-se estacionário. A partir deste ponto, o crescimento no produto per capita só pode acontecer com aumento na produtividade total dos fatores, ou seja, vai depender da taxa de progresso técnico na economia.

\footnotetext{
${ }^{9}$ SOLOW, R. A Contribuition to the Theory of Economic Growth. Quarterly Journal of Economics, 70: p.65-94. 1956.
} 
Solow, em $1957^{10}$, para identificar a contribuição do progresso técnico, utiliza uma função de produção agregada, onde o produto pode ser escrito em função dos $n$ insumos $\mathrm{X} 1, \mathrm{X} 2, \ldots, \mathrm{Xn}$, e do fator tempo, de tal forma que

$\mathrm{Y}=\mathrm{F}(\mathrm{X} 1, \mathrm{X} 2, \ldots, \mathrm{Xn}, \mathrm{t})$

Diferenciando a equação (10) com relação ao tempo e dividindo pelo produto (Y), encontra-se

$(Y t-Y t-1) / Y t=\Sigma \alpha i[(X i t-X i t-1) / X i t]+F t / Y$

onde, $\alpha \mathrm{i}=(\mathrm{Xi} \delta \mathrm{F} / \delta \mathrm{Xi}) / \mathrm{Y}$. Os resultados encontrados por Solow mostram que em sua maior parte as fontes de crescimento da economia dependem do crescimento da produtividade total dos fatores, $(\mathrm{Ft} / \mathrm{Y})$. Portanto, grande parte das fontes de crescimento do produto permanecem inexplicadas pelo modelo, constituindo uma variável exógena chamada "progresso técnico", ou, como é conhecido também, residual de Solow"

Acumular capital, mesmo não sendo a única fonte de crescimento econômico, não deixa de ser questão fundamental com a qual os países se deparam. Nos modelos dualistas evidencia-se a preocupação de como uma sociedade tradicional, com baixas taxas de poupança, pode acumular capital para financiar o crescimento econômico. Nestas sociedades, compostas basicamente por camponeses, que visam sobretudo a própria subsistência, a baixa taxa de poupança pode dificultar o processo de desenvolvimento econômico, fortemente dependente do desempenho do setor agrícola.

Antes de analisar as contribuições que o setor agricola pode, e deve, oferecer ao desenvolvimento econômico, cabe entender como esse setor pode viabilizar o seu próprio desenvolvimento. Como gerar poupança em um país caracterizado predominantemente por um setor agrícola tradicional, questão discutida por Lewis e Fei e Ranis, permanece obscura mesmo com a discussão anterior.

${ }^{10}$ SOLOW, R. Technical Change and the Aggregate Production Function. Review of Economics and Statistics, 39: p 312-320. 1957. 
Ademais, convém fazer outras perguntas que podem ajudar a esclarecer tal problema. Por que na agricultura tradicional as taxas de poupança são baixas ? Em que condições torna-se vantajoso investir na agricultura ? Schultz (1964), discute amplamente estas questões, dando uma nova perspectiva ao assunto. Schultz mostra que não será vantajoso qualquer investimento na agricultura, a menos que "o homem que se dedica à agricultura tenha a oportunidade e o incentivo para transformar a agricultura tradicional dos seus antepassados".

A baixa taxa de poupança não parece ser apenas fruto da falta de mentalidade empresarial, como destacaram Fei e Ranis. Na verdade, argumenta Schultz, não se poupa na agricultura tradicional pois não há incentivos para fazê-lo. Os fatores de produção, responsáveis pelos fluxos de serviços (produtivos), ou no termo empregado por Schultz, as fontes de corrente de renda permanente, são relativamente caras, então, as taxas de retorno aos investimentos em fatores de produção tradicionais são baixas.

Para estimular poupança na agricultura tradicional é necessário, dentro desta lógica, descobrir fontes de corrente de renda de preços suficientemente baixos. Portanto, como ressalta Schultz, o crescimento econômico proveniente do setor agrícola de um país pobre depende predominantemente da disponibilidade e do preço dos fatores agrícolas modernos.

Analisando o proposto por Schultz, torna-se nítido o papel que a indústria desempenha, como fonte dos insumos modernos, no desenvolvimento do setor agrícola. Falta, porém, entender a importância da dinâmica entre os setores agrícola e industrial, para uma compreensão maior do papel desempenhado pela agricultura no processo de desenvolvimento econômico.

Johnston \& Mellor (1961) discutem esta questão, enumerando cinco importantes papéis desempenhados pelo setor agrícola, quais sejam, fornecer alimentos para a população total e matérias-primas à indústria em expansão; fornecer capital à economia; fornecer ganhos cambiais; fornecer mão-de-obra ao setor não agrícola e proporcionar

\footnotetext{
"A apresentação do modelo de Solow foi baseada em Stern, 1994 e Araújo e Schuh, 1991.
} 
mercado para os produtos do setor não agrícola. Aspectos, estes, que estão em concordância com o trabalho de Owen (1975), que divide esta necessidade de participação da agricultura no processo de desenvolvimento em dois diferentes aspectos de pressão sobre o setor, "a pressão de produção" e a "pressão dos gastos".

Owen identifica como "pressão de produção sobre a agricultura" a "requisição intersetorial de incrementos da produção agrícola"; e "pressão de renda sobre a agricultura" como a "requisição de renda agrícola residual para finalidades essencialmente não agrícolas ou finalidades sociais".

A contribuição da agricultura ao desenvolvimento é, portanto, maior que aquela apontada por Lewis. Por esta razão, exige-se do setor agrícola crescimento que possibilite transferência de excedentes ao setor urbano-industrial. No entanto, como enfatiza Nicholls (1975), se uma parte do produto excedente na agricultura não puder ser, por algum motivo, vendido no mercado internacional, a tendência será apenas de crescimento populacional. Idéia semelhante àquela apresentada por Ricardo, descrita anteriormente, que pode ser importante principalmente em paises que se encontram nas etapas iniciais do processo de desenvolvimento.

O crescimento da indústria, por sua vez, exige da agricultura ser mercado para produtos industrializados, como já enfatizado no modelo de Fei \& Ranis e Johnston \& Mellor. Por sua vez, crescimento do produto agrícola depende de progresso tecnológico que, como ressalta Schultz (1964), depende da utilização dos insumos modernos, produzidos na própria indústria.

Esta interdependência agricultura-indústria viabiliza o crescimento de ambos setores em um processo que tende perpetuar as mesmas relações intersetoriais. A população urbana crescente exige, para que o crescimento do setor não agrícola continue, uma oferta também crescente de alimentos e matéria-primas, que no mercado competitivo se traduz em benefício ao consumidor, urbano ou rural, através da redução progressiva dos preços dos produtos agrícolas. 
O modelo agrícola da maioria dos países, caracterizado pela presença de um grande número de produtores e muito próximo de um mercado competitivo, favorece a rápida dispersão da inovação tecnológica. Assim, a transferência deste benefício ao consumidor, via redução de preços, é quase imediata. No setor industrial, o número reduzido de firmas possibilita que o empresário aumente sua margem de lucro, retardando a transferência do ganho tecnológico ao consumidor.

Apesar do progresso tecnológico beneficiar tanto consumidores urbanos quanto rurais, esta diferente estrutura de mercado entre os setores afeta a forma como as transferências intersetoriais se processam. A evidência empírica mostra que, mesmo em países desenvolvidos, o resultado deste processo é uma transferência positiva de recursos da agricultura em direção ao setor não agrícola.

Esta "pressão de produção sobre a agricultura" mostra-se importante ao crescimento global da economia em países desenvolvidos e, principalmente, nos países em desenvolvimento. $\mathrm{O}$ crescimento do produto agrícola assume, neste sentido, um papel importante no processo de desenvolvimento que, na linha de raciocínio do modelo de Solow, traduz-se na necessidade de acumular capital e aumentar a produtividade total dos fatores no setor agrícola.

Aumentar a produtividade total dos fatores implica a necessidade de progresso tecnológico. Este processo de geração, adoção e difusão de tecnologia é condicionado por fatores econômicos, politicos e sociais. Hayami \& Ruttan (1988), estudando a evolução tecnológica dos processos produtivos nos Estados Unidos e Japão, mostram a importância dos preços relativos dos fatores como indutores das inovações tecnológicas. $\mathrm{Na}$ lógica deste modelo, a escassez dos recursos, percebida pelos agricultores e pesquisadores devido ao preço relativo mais alto, determina o sentido da pesquisa tecnológica, qual seja, poupar o fator escasso.

A experiência americana e japonesa, utilizada como evidência empirica do modelo, mostra que no Japão a tecnologia desenvolveu-se, primeiramente, no sentido de poupar terra, fator mais escasso no país. Isto ocorreu com inovações biológicas, o que 
elevou a produtividade por área. Nos Estados Unidos a ênfase foi para as inovações mecânicas, visando o aumento da produtividade por trabalhador, uma vez que neste país o fator escasso era mão-de-obra.

No entanto, em alguns países, apenas a sinalização dos preços relativos não se mostra suficiente para entender o estimulo responsável pela geração de novas técnicas. De Janvry (1973) considera, em seu modelo, que as instituições de pesquisa geram tecnologia não só visando poupar o fator escasso, mas também influenciadas por pressões políticas. Grupos sociais influenciam as decisões das instituições de pesquisa conforme seus próprios interesses. A força política dos diferentes grupos de pressão é fator preponderante na determinação dos rumos da pesquisa.

Instituições públicas são mais susceptíveis às pressões políticas do que as privadas. No entanto, o interesse privado limita-se às áreas de pesquisa que possibilitem à empresa capturar os ganhos provenientes do lançamento da nova tecnologia. Neste sentido, normalmente, pesquisas na área mecânica são mais interessantes para o setor privado do que pesquisas biológicas.

Griliches (1957), destaca que o interesse das empresas de pesquisa em determinada área vai depender, principalmente nas empresas privadas, da lucratividade relativa. Lucratividade que, por sua vez, depende do eventual tamanho do mercado na área, dos custos de mercado, do custo de inovação na área e da taxa esperada de aceitação da nova tecnologia.

O produtor irá adotar nova tecnologia quando o aumento esperado de produtividade, oriundo da adoção da inovação, indicar um aumento de lucratividade. Quanto mais alta for a lucratividade esperada maior será a propensão do produtor em adotar a nova tecnologia. Não existe, no entanto, uma taxa de lucratividade comum a todos os agricultores. A aversão individual ao risco, grau de instrução e outras características sociais influenciam a tomada de decisão e a taxa de lucratividade que induz cada produtor a efetuar a mudança no seu processo de produção. 
Schultz (1964), ressalta que a adoção da tecnologia depende do esperado aumento da rentabilidade ocasionada pela utilização da nova tecnologia, o que irá determinar maior ou menor lucratividade. No entanto, segundo Schultz, o aumento relativo da produtividade não é o fator determinante e sim o aumento absoluto. Dentro desta ótica, agricultores que já alcancem níveis mais altos de produtividade apresentam propensão maior a aceitar nova tecnologia em relação a propriedades menos produtivas.

À medida que os produtores adotam a nova tecnologia, a produção tende a crescer, pois há ganhos de produtividade. Este aumento na oferta de produto, com o mercado em equilíbrio, tende a reduzir os preços e, em seguida, a lucratividade esperada da adoção desta nova tecnologia diminui. Portanto, como salienta Paiva (1975), os produtores retardatários neste processo tendem a ter cada vez menos incentivo para adotar a nova tecnologia.

Note que o retardatário na adoção de novas técnicas provavelmente será o agricultor com baixa produtividade. Desta forma, este processo de geração e difusão de tecnologia pode, por sua própria natureza, induzir a um dualismo tecnológico no setor agrícola. Uma parcela dos produtores, seja por pressão política ou por adotarem mais rapidamente as novidades tecnológicas, modernizam a produção e outra parcela de agricultores mantém-se como tradicionais.

Parte dos agricultores que não adotam as novas tecnologias deve sair do setor, pois o seu custo de produção tornará inviável sua atividade, dirigindo-se para regiões urbanas em busca do emprego no setor não agrícola. $O$ aumento da produtividade do trabalho na agricultura libera parte da mão-de-obra para, também, ser utilizada nos demais setores da economia. Este processo migratório, que no início do desenvolvimento dos países é uma importante fonte de trabalhadores para a indústria, constitui o que Owen caracterizou como a segunda pressão sobre a agricultura, qual seja, a "pressão de renda".

Esta população migrante constitui um alto custo para o setor agrícola, pois este arcou com as despesas de criação e educação desses trabalhadores. Admitindo que os 
trabalhadores que deixam a agricultura são aqueles mais bem treinados e com menor aversão ao risco, o custo deste processo migratório, devido ao fator qualidade, torna-se ainda mais alto. Os fatores que determinam o processo migratório, assim como a importância econômica deste processo para o crescimento, serão discutidos com maior detalhe posteriormente.

Quando o crescimento do setor não agrícola é incapaz de absorver todos os trabalhadores disponíveis no país, as despesas referentes a essa mão-de-obra redundante tende ficar às expensas do setor agrícola. Owen sugere "a criação deliberada de dois subsetores na agricultura: um para maximizar a produção de bem-estar social para o excedente de trabalho e outro para explorar inteiramente a dinâmica do modelo MillMarshaliano, com vistas ao desenvolvimento".

O conceito de desenvolvimento agrícola, na ótica apontada por Owen, não deve ser visto apenas como a necessidade de aumento da produção. Propriedades rurais que empregam alta tecnologia na busca de ganhos de produtividade, responsáveis por boa parte do produto gerado no setor, devem conviver, ao menos enquanto o país não é plenamente desenvolvido, com propriedades tradicionais e, muitas vezes, de subsistência.

Até este ponto, ressaltou-se, utilizando principalmente modelos mais "antigos" da teoria de crescimento econômico, duas importantes fontes de crescimento, acumulação de capital e pesquisa, desenvolvimento e inovação tecnológica. Destacouse, ainda, o papel desempenhado pelo setor agrícola no processo de desenvolvimento, principalmente como fonte de capital para estimular o surgimento e crescimento do setor industrial. Ainda não foram discutidos outros determinantes de crescimento que, no modelo de Solow, se "escondem" por trás do chamado resíduo.

Stern (1991), enumera seis importantes determinantes do crescimento: (i) acumulação de capital, (ii) pesquisa, desenvolvimento e inovação, (iii) capital humano, (iv) gerenciamento e organização, (v) infra-estrutura, e (vi) alocação de produto diretamente em setores produtivos. As deficiências na infra-estrutura, junto com fraca 
capacidade de gerenciamento e organização econômica, são, como ressalta Stern, parte importante na explicação da baixa produtividade total dos fatores nos países em desenvolvimento. No entanto, elas fogem do escopo deste trabalho.

Alocação de produto diretamente nos setores produtivos também é um fator determinante do crescimento que não será discutido em profundidade neste estudo. No entanto, é importante salientar que quando partes do produto e da força de trabalho são utilizadas por setores que não contribuem para aumentar o produto do país, a taxa de crescimento da renda nacional é reduzida.

Capital humano sim, é aqui examinado em maior destaque. Primeiro, a título de entender a importância desse determinante na teoria do crescimento, vale examinar brevemente como os modelos mais recentes incorporam o fator capital humano. Posteriormente, em capítulo a parte, serão examinados os conceitos que se "escondem" neste termo.

A idéia de o capital humano ser um importante determinante do crescimento econômico não é nova. Na verdade, a leitura de trabalhos dos economistas clássicos mostra que desde aquela época eles já se preocupavam com a importância deste fator. Porém, incluir formalmente este conceito nos modelos de crescimento não foi tarefa trivial. Solow (1957) destaca que parte substancial do resíduo não explicado em seu modelo está relacionado com o capital humano, como variável exógena.

No modelo formulado por Arrow e Sheshinski, baseado nas idéias apresentadas por Arrow (1962) em seu clássico trabalho sobre as implicações do processo de learning-by-doing, o capital humano começa a ser trabalhado formalmente em modelos de crescimento econômico. A idéia principal por trás deste modelo é que a sociedade acumula, ao longo do tempo, um volume de conhecimentos que pode ser utilizado por qualquer firma a custo zero. Quando uma firma investe em nova tecnologia, os novos conhecimentos, na verdade, vão sendo acumulados e ficam a disposição para o uso por qualquer agente econômico.

Arrow utiliza uma função de produção para a firma, que pode ser escrita como 
$\mathrm{y}=\mathrm{F}(\mathrm{k}, \mathrm{Bl})$

sendo: $\mathrm{y}=$ produto por firma

$$
\begin{aligned}
& B=f(k) \\
& 1=\text { número de trabalhadores por firma } \\
& k=\text { capital por firma }
\end{aligned}
$$

A forma funcional de B foi escolhida por Arrow com base em trabalhos empíricos realizados na indústria aérea, como

$\mathrm{B}=\mathrm{K}^{\gamma}$, sendo $\gamma<1$

Como implicação das equações (12) e (13), diferente do modelo de Solow, os retornos são crescentes à escala, ou seja, o aumento na quantidade de capital e trabalho, gera aumento mais que proporcional do produto, pois a produtividade do trabalho aumentará com o aumento de B. A variável B representa, justamente, o nível de conhecimento acumulado na economia. Portanto, o nível de conhecimento adquirido pelos trabalhadores relaciona-se diretamente com a quantidade de capital acumulado na economia.

Assumindo que o número de firmas na economia seja igual a $\mathrm{N}$ e constante. $\mathrm{E}$ mais, que as firmas aumentem a oferta de emprego à mesma proporção que cresce a força de trabalho, uma taxa $\mathrm{n}$, a taxa de crescimento da economia no estado estacionário no modelo de Arrow e Sheshinski será dada por

$\mathrm{g}=\mathrm{n} /(1-\gamma)$

Para chegar a esta taxa de crescimento partiu-se do pressuposto que, na equação (12), a função apresenta retornos constantes à escala com respeito a $\mathrm{k} e \mathrm{l}$.

Como n e $\gamma$ são parâmetros exógenos, medidas de política pública não afetam, na ótica deste modelo, o progresso tecnológico. Note, também, que se o crescimento populacional for nulo, não haverá progresso técnico. Essas implicações do modelo não 
parecem ser condizentes com as evidências empíricas. Por isso, os modelos de crescimento endógeno procuram trabalhar no sentido de corrigir estes problemas.

Romer (1986) propõe um modelo semelhante ao apresentado por Arrow e Sheshinski, porém, considera $\gamma$ igual a um. Assume também que n é igual a zero, pois do contrário, com $\gamma=1$, a taxa de crescimento do produto e capital tenderia ao infinito. A taxa de poupança das firmas é determinada pelas decisões de maximização intertemporal dos proprietários-consumidores.

A otimização intertemporal, que determina a taxa de poupança, no modelo de Romer é basicamente o modelo de otimização de dois períodos quando a taxa marginal de substituição entre consumo presente e futuro é igual a taxa marginal das oportunidades de investimento. Em outras palavras, a taxa de desconto do consumo deverá ser igual ao produto marginal do capital, ou a taxa de retorno. Esta é a chamada condição de Ramsey ${ }^{12}$.

Maior discussão sobre o modelo de Romer pode ser encontrada em Stern $(1994)^{13}$. Cabe aqui salientar algumas implicações importantes deste modelo e que influenciam outros modelos de crescimento endógeno. No modelo de Romer, produto, consumo e capital crescem à mesma taxa, assim como o produto per capita, já que a população é constante por pressuposição do modelo.

Outra importante implicação do modelo é a proporcionalidade da relação entre produto e capital. Na verdade, este resultado representa uma volta ao modelo de HarrodDomar. Lembre que pela condição de Harrod-Domar, a taxa de crescimento do capital, $\mathrm{s} / \mathrm{v}$, com $\mathrm{v}$ constante, também é a taxa de crescimento do produto. Portanto, medidas de políticas públicas podem influenciar a taxa de crescimento.

A proporcionalidade entre produto e capital na função de produção também é a essência do modelo apresentado por Rebelo (1990). Este modelo mostra que taxar a

\footnotetext{
${ }^{12}$ RAMSEY, F. A Mathematical Theory of Saving. Economic Journal, 38. P 543-559. 1928.

${ }^{13}$ STERN, N. Growth theories, old and new, and the role of agriculture in economic development. Apostila, Sep. 1994, 149p.
} 
renda reduz a taxa de crescimento uma vez que reduz o produto marginal percebido pelos proprietários-consumidores. Outro exemplo de modelo que utiliza a proporcionalidade entre produto e capital foi apresentado por Barro (1990), que inclui os gastos do governo na função de produção agregada, que devem ser proporcionais ao capital.

Além da proporcionalidade entre produto e capital, estes modelos têm em comum a influência que o processo de aprendizado exerce sobre a produtividade do investimento. Conceito encontrado também no modelo de Uzawa e Lucas descrito em detalhes por Stern (1994).

Lucas (1993), utiliza a função de produção como $\mathrm{Y}=\mathrm{F}(\mathrm{K}, \mathrm{uhL})$

Onde u é a fração do tempo de não lazer devotada ao trabalho e h é a produtividade do tempo de trabalho. Portanto, o investimento que as pessoas realizam pode ser feito visando o aumento do estoque de capital ou o aumento da produtividade do tempo de trabalho. Em outras palavras, pode-se investir, visando o aumento da produção, em duas distintas formas de capital, o capital não-humano e o capital humano.

Conceito implícito em muitos modelos de crescimento endógeno, como no modelo de Romer, é o da existência de externalidades na acumulação de capital, ou seja, o retorno ao capital excede o seu retorno social. Assim, a elasticidade renda com respeito ao estoque de capital físico seria maior que a participação deste capital na renda.

Utilizando uma ampliação do modelo de Solow, que visa incluir o estoque de capital humano às variáveis utilizadas por Solow, capital fisico e trabalho, Mankiw et al. (1992), mostram que estas conclusões dos modelos endógenos não são necessariamente verdadeiras. Estes autores não encontraram nenhuma evidência empírica que comprove a existência de externalidades ao estoque de capital.

O modelo de Solow ampliado, como proposto por Mankiw et al., evidencia que diferenças nas taxas de poupança, educação e crescimento populacional podem explicar 
as diferenças na renda per capita entre os países. Importante neste modelo é que, apesar de mais lentamente que o previsto por Solow, as rendas per capita dos países tendem a convergir.

Se existem ou não retornos à escala na economia, como predizem alguns modelos de crescimento endógeno; ou, ainda, se acumular capital gera externalidades, talvez ainda seja motivo de debate na literatura econômica por um bom tempo. A agricultura, por sua vez, apresenta determinadas particularidades que a tornam distinta dos demais setores da economia. O ganho de escala não é evidente neste setor e, ao padrão agrícola atual, parece mais sensato admitir que, ao menos na agricultura prevalecem os retornos constantes à escala. Na discussão presente, ressaltar o papel que o capital humano desempenha no processo de desenvolvimento econômico dos países é o ponto de interesse.

\subsubsection{O capital humano}

"The most valuable of all capital is that invested in buman beings"

Alfred Marsball

A leitura dos trabalhos dos economistas clássicos como Ricardo e Smith não deixa dúvidas que já naquela época era reconhecida a importância da qualidade e das habilidades do trabalhador na produção. No entanto, durante muito tempo este conceito não foi bem definido e os modelos de crescimento não davam destaque formal a esta questão.

Schultz e Becker foram pioneiros ao trabalhar mais profundamente o assunto, formalizando o conceito e o papel desempenhado pelo capital humano no processo de crescimento econômico. Como definido por Schultz (1973), capital humano "é humano porque se acha configurado no homem e é capital porque é uma fonte de satisfações futuras ou de futuros rendimentos, ou de ambas as coisas". Becker (1993), completa o 
conceito destacando que não se pode separar a pessoa do seu conhecimento, habilidade, saúde e outros aspectos que determinam o capital humano.

Os diferentes aspectos do investimento em capital humano têm em comum melhorar a qualidade do homem e, consequentemente, sua produtividade no trabalho. Esses aspectos são, principalmente: cuidados com a saúde; educação adicional; procura por oportunidades de trabalho; resgate de informações, principalmente sobre oportunidades de trabalho; migração; treinamento no trabalho.

Cuidados com as crianças, nutrição, serviços médicos, melhores condições sanitárias, são exemplos de investimentos que visam melhorar a saúde das pessoas. Estas despesas podem ser vistas como investimento em capital humano pois sem dúvida melhoram a qualidade e a produtividade dos trabalhadores. Trabalhador saudável e bem nutrido rende mais. Em regiões pobres, a alimentação insuficiente para garantir a boa nutrição do trabalhador influencia seu rendimento e a própria alocação do tempo dedicado ao trabalho. Muitos povos vistos como indolentes e culturalmente pouco dispostos ao trabalho, na verdade são apenas retratos de trabalhadores mal nutridos (Schultz, 1964).

A qualidade de saúde da população constitui importante estoque de capital ao país. Parte da qualidade do estoque inicial pode ser, como ressalta Schultz (1979), herdado ou adquirido. Outra característica importante é que este estoque é depreciado ao longo do tempo a taxas crescentes em idades mais avançadas.

Dessas características, podem-se inferir importantes conclusões. Deve-se investir na melhoria da saúde da população, pois se aumenta o estoque de capital humano, e, além disso, estes investimentos devem ser permanentes já que este estoque deprecia-se com o tempo. Vale ressaltar que parte do estoque inicial de saúde é "herdado", isso significa que uma geração saudável deve influenciar positivamente futuras gerações.

O aumento da expectativa de vida da população é uma conseqüência direta do estoque de saúde da população de um país. Trabalhadores que esperam por vida mais duradoura apresentam maior disposição para trabalhar e poupar, além de maior interesse 
em investir nas demais formas de capital humano. Assim, melhorar o estoque de saúde da população melhora as condições do país em outros importantes determinantes do crescimento econômico.

População saudável pode melhorar a qualidade e o estoque do capital humano aperfeiçoando suas habilidades através da educação e do treinamento no trabalho. Estas são atividades que apresentam custos diretos e indiretos. Custos diretos são os diretamente relacionados com as atividades, como construção de salas de aula, pagamento de professores, despesas com material didático e todos os cústos diretamente envolvidos no processo. No entanto, estes não são os únicos custos envolvidos quando se fala em investir em capital humano. O tempo despendido nestas atividades, que poderia estar sendo alocado diretamente em atividades produtivas, constitui um importante fator de custo, que pode ser chamado de custo de oportunidade do tempo do trabalhador.

Schultz (1973), destaca três aspectos do porquê as pessoas se educam: (1) educação para o consumo corrente; (2) educação para o consumo futuro, ou seja, investimento em componente duradouro para o consumidor; e, (3) educação para obter capacitações e conhecimentos úteis ao esforço econômico e, assim, investimento nos rendimentos futuros. Nesta ótica, Schultz ressalta que muitos dos gastos tratados como consumo na verdade são investimento em capital humano.

O motivo pelo qual as pessoas utilizam parte do seu tempo em educação e treinamento deve-se à expectativa que suas habilidades aumentarão e, consequentemente, sua produtividade e ganhos monetários. Esta procura por qualidade pode ocorrer dentro das escolas ou no próprio local de trabalho.

Diferentes tipos de necessidade aos quais são expostos os trabalhadores no exercício do seu ofício irão determinar os tipos de educação e treinamento necessários. Habilidades práticas e mais específicas exigem treinamento específico e, se possível, realizado na própria firma. No entanto, o conhecimento abrangente não deve ser 
descartado, pois apenas esse prepara o trabalhador para as constantes mudanças que a tecnologia impõe sobre os processos produtivos.

Assim, escola e treinamento no trabalho devem fazer parte da formação das habilidades profissionais do trabalhador e, apesar de disputarem o mesmo escasso tempo das pessoas; não devem ser encarados como substitutos entre si. Alocar o tempo disponível ao aprendizado diretamente em educação escolar ou em treinamento no trabalho depende da profissão e da etapa de vida de cada pessoa.

Portanto, treinamento no trabalho e educação devem ser vistos como investimentos que têm por fim ganhos financeiros futuros. Como tal, é importante conhecer as taxas de retorno desses investimentos e quem deve arcar com tais despesas em diferentes situações.

Ao ingressar na firma, a produtividade do trabalhador novato provavelmente será inferior a daquele com mais tempo de serviço. À medida que o novo empregado vai se familiarizando com as tarefas que desempenha, sua produtividade tende a aumentar, ou seja, o empregado aprende fazendo, o que aumenta sua habilidade e, em conseqüência, sua produtividade. Este é o conceito conhecido como learning by doing.

Para acelerar o processo de aprendizado, ou mesmo capacitar um funcionário a realizar seu novo serviço, torna-se vantajoso para muitas firmas sacrificar parte do tempo do empregado, que poderia estar sendo utilizado diretamente na atividade produtiva, em atividades de treinamento. Este investimento em capital humano é chamado de treinamento no trabalho (On-the-job training).

O gasto em treinamento, além do custo do próprio tempo do funcionário que está sendo treinado, deve incluir as despesas com o tempo daquele funcionário que servirá como instrutor, além de gastos com material, equipamentos e outros gastos diretos e indiretos. Este sacrificio de produção é feito na expectativa de aumento da produtividade futura do trabalhador.

Conforme as características do mercado e da firma, o treinamento que o empregado deve receber pode ser útil em muitas outras firmas, ou limitar-se àquela 
firma em questão. Quanto mais específico for o treinamento necessário dentro de uma firma, mais dificil será a utilidade deste treinamento quando o empregado mudar de emprego. Portanto, existem dois diferentes tipos de treinamento no trabalho, o geral e o específico.

Becker (1993), analisa formalmente esta questão, mostrando que no caso do treinamento geral a firma terá pouco ou nenhum incentivo em arcar com os custos deste investimento, portanto, o próprio funcionário, já que ele usufruirá deste treinamento em qualquer outra firma do mercado, deve arcar com este custo. No caso do treinamento específico, o funcionário terá pouco incentivo para arcar com este custo, pois este conhecimento só poderá ser utilizado naquela firma. Logo, o custo com o treinamento será pago pela própria firma.

Entre treinamento geral e específico, existe uma gama infinita de combinações. Nesses casos intermediários, a estrutura do mercado na qual a firma está inserida, a situação do próprio mercado de trabalho e outras condições determinarão quem e em que percentual irá arcar com os custos do treinamento no trabalho. De qualquer maneira, não resta dúvida deste ser um importante aspecto do investimento em capital humano.

Becker (1993), define a escola como "uma instituição especializada na produção de treinamento, que é distinta da firma que oferece treinamento em conjunto com a produção de bens". A decisão de investir em educação, da mesma forma que os investimentos em treinamento, deve-se à expectativa de melhorar os rendimentos futuros e, assim, as condições de vida da pessoa que se educa. Este é o retorno privado à educação.

Os retornos à educação não se limitam a esfera privada. Existe uma série de ganhos para a sociedade quanto maior for o número de pessoas que se educam. Um ganho social primordial possibilitado pela educação é a redução do tamanho das famílias, que melhora a qualidade de vida das pessoas, reduzindo a pobreza. A educação contribui para reduzir a fertilidade líquida da população, como previsto pelo modelo de 
Becker, Murphy e Tamura (1990), e constatado pelo trabalho econométrico de Barro (1991).

As taxas de retorno ao capital físico, de poupança e de crescimento econômico de toda nação dependem diretamente da escolaridade da população, como ressaltam diversos modelos teóricos de crescimento econômico, anteriormente discutidos. Assim, mais importante que apenas o retorno privado ao investimento em educação, existe retorno social a este investimento.

Para medir a taxa de retorno privado à educação, metodologia bastante empregada nos trabalhos empíricos, foi desenvolvida nos estudos de Becker (1993) e de Schultz (1962). Consiste em mensurar a taxa interna de retorno a este investimento. Ou seja, estimar uma taxa de desconto que iguale os valores presentes dos custos e dos beneficios da escolaridade.

Os trabalhos empíricos normalmente mostram que as taxas de retorno ao investimento em educação são elevadas. Becker (1993), traz uma extensa discussão sobre a taxa de retorno à educação nos Estados Unidos. Para o Brasil, diversos autores trabalharam o assunto. Castro (1971), compara os resultados de três diferentes trabalhos disponíveis na época ${ }^{14}$. As taxas de retorno encontradas variam entre aproximadamente $10 \%$ até pouco mais de $40 \%$, conforme o ciclo de estudos completos considerados na análise.

Os resultados discutidos por Castro (1971) destacam a importância e a alta taxa de retorno encontrada para a educação primária (da ordem de 20 a $40 \%$ ). Este autor encontrou para a educação universitária taxas em torno de 10 a $15 \%$. As taxas de retorno à educação secundária situam-se entre as encontradas para a educação primária e a universitária. O estudo de Gibbon (1975) traz resultados muito semelhantes e consistentes com os encontrados por Castro.

\footnotetext{
${ }^{14}$ Os estudos utilizados por Castro (1971) são: Langoni, C. A Study in Economic Growth: The Brasilian Case. Tese de PhD para a Universidade de Chicago, 1970; Castro, C. Investiment in Education in Brazil: A Study of Two Industrial Communities. Tese $\mathrm{PhD}$ para a Universidade de Vanderbilt; Levy, S. An Economic Analysis of Investment in Education in State of São Paulo. Instituto de Pesquisas Econômicas USP, 1969.
} 
Singh (1989) encontrou uma taxa menor de retorno à educação (na faixa de $14 \%$ a $15 \%$ ). No entanto, como o autor ressalta, é importante destacar que este estudo foi realizado em áreas de agricultura tradicional. A menor taxa de retorno da escolaridade na zona rural, quando em comparação com áreas urbanas, é coerente com os resultados encontrados por Kassouf (1997).

Welch (1970), ressalta que "a educação não deve ser vista apenas como um investimento, mas também como um fator de produção". Segundo Welch, não considerar este aspecto da educação afeta a analise do retorno dos investimentos em pessoas. Griliches (1975) introduziu, explicitamente, o nível de despesas públicas com educação, pesquisa e extensão agrícola na função de produção agregada da agricultura americana. $\mathrm{O}$ trabalho de Griliches mostra que a educação é um fator que influencia diretamente a produção.

Evidências empiricas motivaram Welch a trabalhar com um conceito mais abrangente de educação, como destaca Becker (1993). Como todo investimento, a taxa de retorno deveria diminuir à medida que a oferta de mão-de-obra qualificada fosse ampliada. No entanto, os dados da economia norte-americana não confirmaram esta expectativa. Ao contrário, a taxa de retorno aos investimentos em educação aumentaram ao longo do tempo, mesmo com o aumento na oferta de trabalhadores com maior qualificação.

Welch (1970), discute três possíveis explicações para este fato: (1) o crescimento do produto industrial, sabidamente exigente em pessoas habilitadas; (2) não-neutralidade na produção, ou seja, mudanças na composição do sistema produtivo aumentando a demanda por educação; e, (3) mudança na "qualidade" da educação; com maior assimilação de habilidades por tempo despendido com aprendizado, o retorno à educação aumenta.

Focando os fatores que determinam o valor da produtividade da educação na indústria, Welch (1970), considera que os retornos à educação podem derivar de dois efeitos distintos: efeito trabalhador e efeito alocativo. $\mathrm{O}$ aumento da educação permite ao 
trabalhador produzir mais com os recursos em mãos. Este é o efeito trabalhador. Mas, o aumento da educação pode aumentar, também, a habilidade do trabalhador em adquirir e decodificar informações sobre características produtivas e de custos dos outros insumos, o que constitui o chamado efeito alocativo.

Considerar a existência destes dois efeitos quando do aumento da educação pode, segundo Welch, explicar porque resultados tão diferentes são encontrados em trabalhos que, de modo similar, utilizam a educação como um fator explícito na função de produção. Welch compara os resultados obtidos por Griliches (1975) com os de Kislev $^{15}$. No trabalho de Griliches a educação foi importante fonte de produtividade, enquanto Kislev encontrou apenas contribuições modestas ou nulas. Welch destaca que o nível de agregação dos dados utilizado pelos autores, estadual em Griliches e municipal em Kislev, deve ser a chave para entender estas diferenças. Segundo Welch, a agregação estadual permite captar ganhos alocativos, devido a maior diversidade de produto, vis-à-vis, a agregação municipal.

Welch destaca ainda a importância da dinâmica tecnológica como fator de estímulo à educação. Ressalta que "se a tecnologia torna-se estagnada, o incentivo é reduzido e pode desaparecer".

Trabalhando com um modelo que relaciona qualidade de produtos, capital humano e crescimento econômico, Stokey (1991) ressalta que o treinamento e a educação dos trabalhadores são complementares aos investimentos em pesquisa e desenvolvimento (P\&D).

Trabalhadores saudáveis, educados e treinados podem, no entanto, apresentar baixa produtividade se estiverem mal alocados. Desta forma, como ressalta Schultz (1962), a migração é considerada capital humano pois melhora a produtividade desta fonte de renda, anteriormente mal alocada, levando-a até onde possa ser melhor utilizada. Por este motivo, também, a busca por informações quanto a melhores

15 Kislev, Voav. "Estimating a Production Function from U.S. Census Agriculture Data."Ph.D dissertation, Univ. Chicago, 1965. Citado por Welch (1970). 
empregos e a própria procura por melhores empregos podem ser considerados investimentos em capital humano.

A migração não é um processo simples, quando as pessoas, diante de melhores oportunidades de trabalho, mudam em busca do novo emprego. Fatores econômicos, sociais, políticos e geográficos determinam o processo migratório. $\mathrm{O}$ que atrai as pessoas para determinada região é a expectativa de maior renda. Portanto, diferenciais de renda entre as regiões impulsionam o processo migratório, (Beals et al., 1967; Vanderkamp, 1971).

Vanderkamp (1971) destaca que as regiões de alta renda, que se tornam atrativas, acumulam populações "móveis". Assim, ceteris paribus, uma região de alta renda deverá apresentar maior taxa de out-migration que regiões de baixa renda. Como destaca Greenwood (1969), o estoque de migrantes é importante variável determinante da migração. Sahota (1968), acrescenta que a distância é um fator importante na tomada de decisão das pessoas quanto a migrar ou não. Além do custo de deslocamento que cresce com a distância, existem aspectos sociais como: estar distante de amigos e familiares e as diferenças culturais.

Beals et al. (1967) destacam a influência da urbanização e da densidade populacional na decisão de migrar. $O$ potencial de uma região em absorver pessoas reduz-se quando a população cresce. No Brasil, Alves (1995), aponta as melhores condições de emprego e de infra-estrutura social nas cidades e a falta de investimentos em educação, saúde e habitação no meio rural como os principais responsáveis pela migração rural-urbana ocorrida no país.

Harris \& Todaro (1970) salientam que a migração rural-urbana existe enquanto a esperada renda real urbana na margem excede a renda agrícola real. Como discutido na seção anterior, à medida que o setor agrícola perde importância relativa, e a produtividade do trabalhador urbano torna-se mais alta que a do trabalhador rural, a migração deve ocorrer no sentido campo cidade. No entanto, quando a produtividade média nas zonas rurais e urbanas se aproximam este processo não necessariamente irá 
continuar. Assim, como salienta Sahota (1968), a urbanização per se não é um importante fator determinante da migração, sendo que a migração rural-urbana é condicionada muito mais pelos aspectos econômicos.

Características individuais também são importantes variáveis determinantes da migração. A educação e a idade das pessoas influenciam a disposição para migrar. Pessoas mais jovens tendem a migrar mais facilmente, assim como pessoas com maior grau de educação (ver Sahota, 1968; Lanzona, 1998; Sjaastad, 1962).

\subsection{Evidências Empíricas}

\subsubsection{A situação atual}

$$
\begin{aligned}
& \text { "... o bomem sem capacitaçoes técnicas e sem } \\
& \text { conbecimentos apoiando-se terrivelmente no nadd". }
\end{aligned}
$$

William Faulkener

Paiva (1975) mostra que a característica dualista do setor agrícola, inerente a natureza do processo de desenvolvimento tecnológico da agricultura, faz com que, à medida que o setor se desenvolva, parcela significativa dos agricultores tenha que deixar a atividade. Aqueles que permanecem praticando agricultura sem tecnologia trabalham com baixo nível de produtividade, baixa renda e pouco incentivo para adotar técnicas modernas de produção.

O estudo de Paiva ajuda a explicar o elevado número de trabalhadores agrícolas não remunerados ou que trabalham para o próprio consumo, 7,4 milhões de pessoas em 1997 , ou $10 \%$ da população economicamente ativa do país, que era 69,3 milhões neste ano. Em 1992, este número era ainda maior, 8,3 milhões em uma população economicamente ativa de 65,4 milhões.

No entanto, esta redução de pouco mais de 1 milhão de trabalhadores não remunerados ou que trabalham para o próprio consumo, entre os anos de 1992 e 1997, não significa que o setor agrícola os tenha incorporado como membros remunerados. É mais provável que esses trabalhadores tenham deixado o setor. Em 1992, 28\% da 
população economicamente ativa do país trabalhavam na agricultura. Em 1997 este número reduziu-se para $24 \%$, ou seja, grosso modo, 3 milhões de pessoas deixaram o setor agrícola em apenas cinco anos ${ }^{16}$.

O fluxo de trabalhadores deixando o setor agrícola talvez pudesse ser mais intenso. No entanto, a redução da taxa de crescimento da oferta de emprego nas décadas de 80 e 90 pode ter diminuído a intensidade desse movimento. Durante a década dos 80 , o êxodo rural, considerando o Brasil como um todo, diminuiu significativamente (Mueller \& Martine, 1997). Nas cidades, houve redução da taxa de crescimento dos ocupados e aumento da taxa de desemprego aberto - incluindo o aumento relativo do número de chefes de família desempregados nas áreas metropolitanas (Cacciamali, 1992).

A porcentagem da população brasileira que retira seu sustento da agricultura ainda é grande quando comparada aos países desenvolvidos (quadro 1). $\mathrm{O}$ diferencial de rendimentos, importante fator que determina os fluxos migratórios, também é elevado quando se comparam salários recebidos pelos trabalhadores do campo com aqueles das regiões urbanas (quadro 2 ).

\begin{tabular}{|l|c|c|c|c|c|c|}
\hline & 1950 & 1960 & 1970 & 1980 & 1990 & 2000 \\
\hline Brasil & 61,6 & 55,2 & 47,2 & 36,7 & 23,3 & 16,7 \\
\hline Mundo & 67,1 & 61,3 & 56,1 & 52,0 & 48,9 & 44,8 \\
\hline Industrializados & 26,7 & 18,8 & 12,0 & 7,9 & 5,5 & 3,7 \\
\hline Baixa Renda & 82,6 & 79,0 & 76,2 & 71,8 & 66,5 & 60,8 \\
\hline EUA & 12,3 & 6,6 & 4,3 & 3,5 & 2,8 & 2,1 \\
\hline França & 30,9 & 22,1 & 13,6 & 8,2 & 5,5 & 3,3 \\
\hline Alemanha & 23,0 & 15,0 & 8,7 & 6,9 & 4,0 & 2,5 \\
\hline Japão & 48,8 & 33,0 & 19,6 & 10,9 & 7,3 & 4,0 \\
\hline Argentina & 25,2 & 20,6 & 16,0 & 12,9 & 12,1 & 9,7 \\
\hline Chile & 32,9 & 30,3 & 24,1 & 20,9 & 18,8 & 15,7 \\
\hline
\end{tabular}

Fonte: FAO

Quadro 1- Percentual da população economicamente ativa empregada no setor agrícola

${ }^{16}$ Fonte: IBGE - PNAD 92 e 97 - Pessoas com 10 anos ou mais, ocupadas na semana de referência. Distingue dos números da FAO (tabela 1), pois esta considera pessoas em idade mais avançada. 


\begin{tabular}{|l|c|c|}
\hline \multicolumn{1}{|c|}{ Região } & Domicílio Rural & Domicílio Urbano \\
\hline Brasil & 172 & 506 \\
\hline Região Norte & 204 & 418 \\
\hline Região Nordeste & 115 & 314 \\
\hline Região Centro-Oeste & 211 & 592 \\
\hline Região Sudeste & 229 & 491 \\
\hline Região Sul & 233 & 524 \\
\hline
\end{tabular}

Fonte: IBGE. Elaboração MEC (Perfil Municipal do Ensino Brasileiro), 1991.

Quadro 2- Rendimento médio mensal real dos chefes de domićlio rural e urbano (em Reais)

Quando anteriormente foram discutidos os determinantes da migração, mostrouse que urbanização per se não é um importante fator que influencia os fluxos migratórios. Portanto, não necessariamente deixar empregos no setor agrícola deveria significar ir para as cidades. Em muitas comunidades rurais, a população retira sua renda de atividades tipicamente urbanas. Este fato explica porque, mesmo com a baixa participação da agricultura no emprego, inclusive em países desenvolvidos, uma parcela significativa da população permanece vivendo em zonas rurais (quadro 3 ).

\begin{tabular}{|l|c|c|c|c|c|c|c|}
\hline & 1970 & 1975 & 1980 & 1985 & 1990 & 1995 & 2000 \\
\hline Brasil & 44,2 & 38,8 & 33,7 & 29,3 & 25,3 & 21,6 & 18,7 \\
\hline Mundo & 63,3 & 62,1 & 60,5 & 58,7 & 56,8 & 54,7 & 52,5 \\
\hline $\begin{array}{l}\text { Países } \\
\text { Industrializados }\end{array}$ & 27,4 & 25,9 & 25,4 & 24,9 & 24,3 & 23,7 & 22,9 \\
\hline $\begin{array}{l}\text { Países de } \\
\text { Baixa Renda }\end{array}$ & 81,8 & 80,1 & 78,3 & 76,6 & 74,8 & 72,5 & 70,2 \\
\hline EUA & 26,4 & 26,3 & 26,2 & 25,5 & 24,7 & 23,8 & 22,8 \\
\hline França & 29,0 & 27,0 & 26,7 & 26,3 & 26,0 & 25,3 & 24,4 \\
\hline Alemanha & 20,3 & 18,8 & 17,4 & 16,0 & 14,7 & 13,5 & 12,4 \\
\hline Japão & 28,8 & 24,3 & 23,8 & 23,3 & 22,6 & 21,9 & 21,1 \\
\hline Argentina & 21,6 & 19,2 & 17,1 & 15,2 & 13,5 & 11,9 & 10,6 \\
\hline Chile & 24,7 & 21,6 & 18,7 & 17,4 & 16,7 & 16,1 & 15,4 \\
\hline
\end{tabular}

Fonte: FAO

Quadro 3- Percentual da população que vive em zonas rurais 
Para manter os trabalhadores nas zonais rurais é necessário que existam condições de infra-estrutura e, sobretudo, de melhor escolaridade para possibilitar o exercício de atividades não-agrícolas nestas regiões. Nas áreas urbanas, por seu turno, depois da forte crise mundial que afetou a economia de muitos países, incluindo o Brasil, em boa parte da década de 90 , a retomada do crescimento econômico deve aumentar a oferta de empregos. No entanto, o crescimento da oferta de empregos deve vir principalmente do setor de serviços (quadro 4 e gráfico1), concentrando-se na necessidade de trabalhadores qualificados, como destacam os estudos de Barros et al. (1997 a, b, c) e Magalhães et al. (1986).

\begin{tabular}{|l|c|c|c|c|}
\hline \multicolumn{1}{|c|}{ Região/Setor } & Agrícola & Indústria & Comércio & Serviços \\
\hline Brasil & 24,5 & 19,9 & 13,1 & 42,5 \\
\hline Norte (urbana) & 12,5 & 18,1 & 18,3 & 51,0 \\
\hline Nordeste & 40,6 & 13,0 & 12,5 & 33,7 \\
\hline Sudeste & 13,5 & 24,3 & 14,0 & 48,5 \\
\hline Sul & 28,1 & 22,2 & 12,1 & 37,6 \\
\hline Centro-Oeste & 23,9 & 15,8 & 13,4 & 46,9 \\
\hline
\end{tabular}

Fonte: Pesquisa Nacional por Amostra de Domicílios (PNAD), 1996.

Quadro 4- Pessoas ocupadas de 10 anos ou mais de idade por ramo de atividade econômica da ocupação principal, em percentagem.

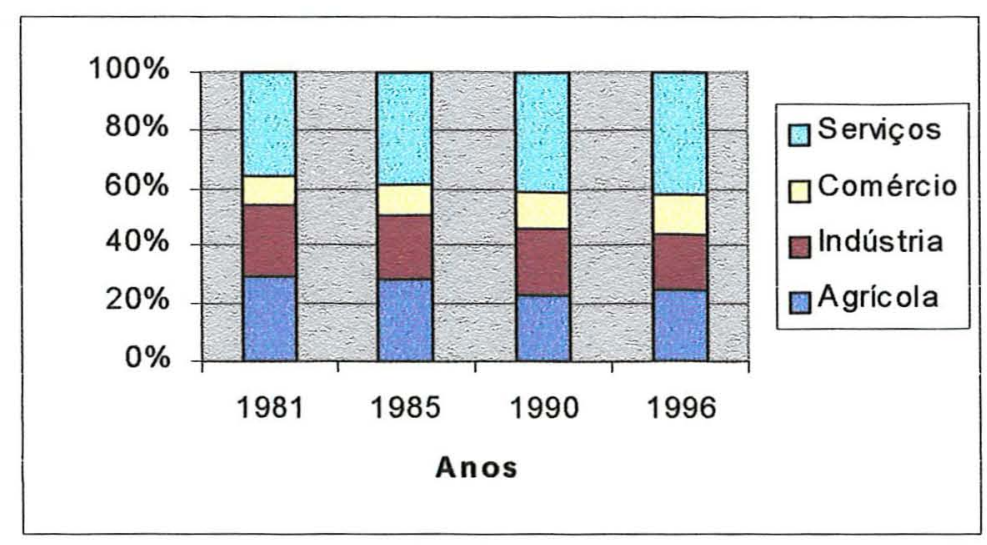

Fonte: PNAD 1981, 1986, 1990, 1997

Gráfico 1- Evolução do perfil de ocupação das pessoas segundo ramo da atividade econômica no Brasil. 
Empregos não-agrícolas tanto nas áreas rurais como urbanas exigem trabalhadores qualificados, o que normalmente não é o caso de boa parte da mão-de-obra empregada na agricultura. O maior número de analfabetos encontra-se nas regiões rurais (gráfico 2). Também no campo concentram-se as pessoas com menos estudo (gráfico 3). Não coincidentemente, o percentual dos trabalhadores rurais que pertencem às classes mais baixas de rendimento é muito grande, principalmente quando comparado com a situação dos trabalhadores urbanos (gráfico 4).

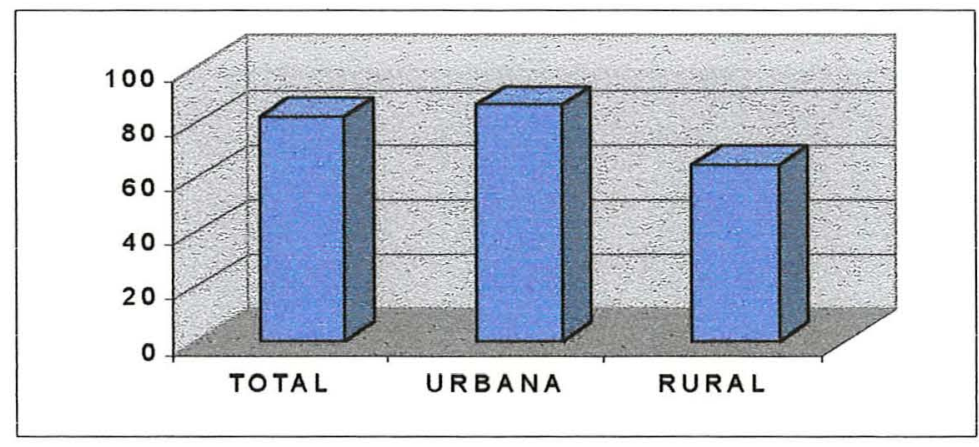

Fonte: PNAD, 1997

Gráfico 2- Percentual de pessoas alfabetizadas segundo domicílio no Brasil.

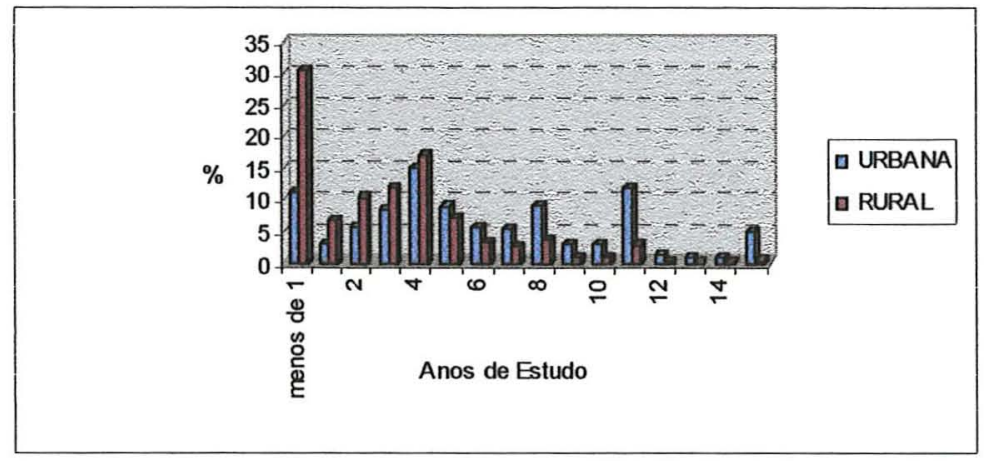

Fonte: PNAD, 1997

Gráfico 3- Anos de estudo da população por situação de domicílio no Brasil. 


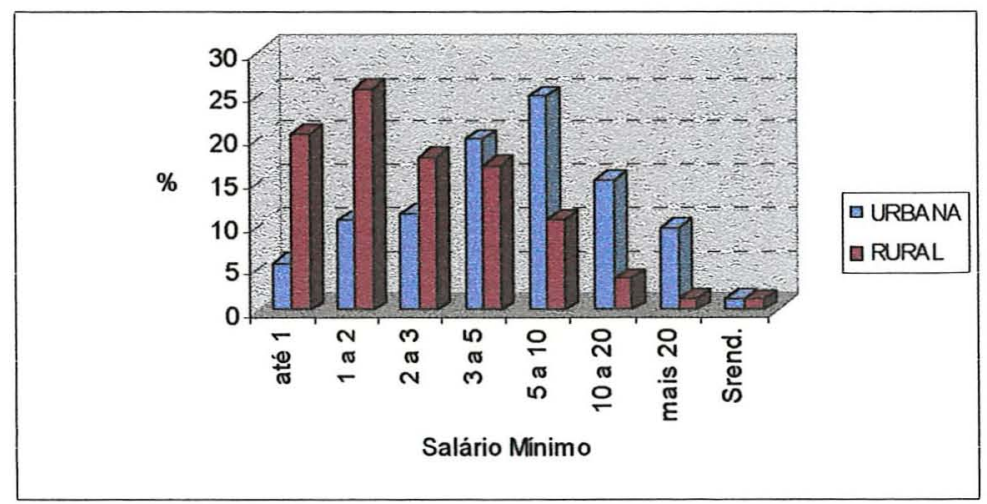

Fonte: PNAD, 1997.

Gráfico 4- Percentual dos moradores de domicílios permanentes, urbanos e rurais, por classe de renda no Brasil.

A baixa escolaridade da população rural dificulta a conquista de melhores oportunidades de emprego e diminui as chances desses trabalhadores aumentarem sua renda. Os dados de 1997 mostram que trabalhadores menos qualificados normalmente ocupam classes de renda mais baixa (gráfico 5).

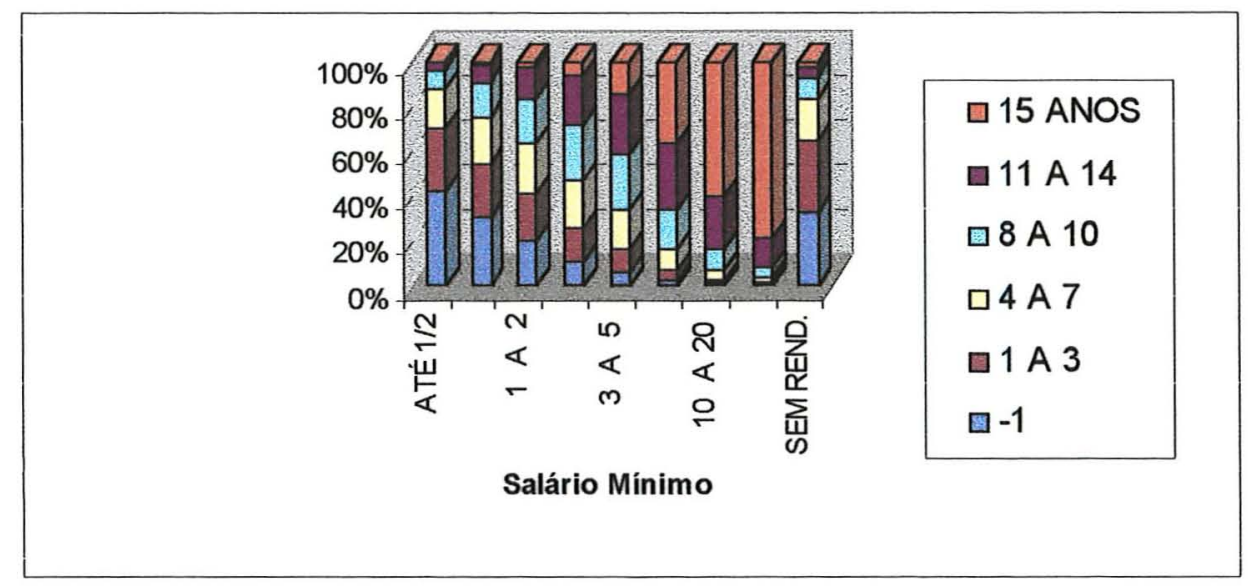

Fonte: PNAD, 1997

Gráfico 5- Percentual de pessoas das diferentes classes de renda segundo os anos de estudo

A menor escolarização das populações rurais reflete, em parte, as dificuldades inerentes ao setor agrícola. Grandes distâncias entre residências e escolas, baixa 
densidade populacional, necessidade de crianças e adolescentes ajudarem nas lides agrícolas são algumas das dificuldades que moradores do meio rural enfrentam quando pretendem ir à escola.

Algumas dessas dificuldades prejudicam a própria estrutura educacional disponível nas zonas rurais. Diferenças estaduais de renda e dos custos da educação também influenciam diretamente o nível de escolaridade da população. As próximas seções trazem um rápido panorama da estrutura educacional brasileira e da questão dos gastos com educação, procurando destacar as diferenças existentes entre os Estados e entre os meios rural e urbano.

\subsubsection{A educação no Brasil}

As diretrizes e bases da educação escolar no Brasil são estabelecidas pela Lei $\mathrm{n}^{\circ}$ 9394 de Dezembro de 1996. Como determina o artigo 21 da referida Lei, a educação

escolar compõe-se de: I- educação básica, formada pela educação infantil, ensino fundamental e ensino médio; II- educação superior. Os currículos do ensino fundamental e médio devem, conforme determinado no artigo 26 da mesma Lei, "ter uma base nacional comum, a ser complementada, em cada sistema de ensino e estabelecimento escolar, por uma parte diversificada, exigida pelas características regionais e locais da sociedade, da cultura, da economia e da clientela".

O texto da Lei 9394 oferece certa liberdade ao sistema de ensino para que sejam feitas, na oferta de educação básica às populações rurais, adaptações consideradas necessárias à melhor adequação do sistema de ensino às peculiaridades da vida rural e de cada região (artigo 28 da lei 9394). Adequar o calendário escolar às fases do ciclo agrícola, às condições climáticas das diferentes regiões e à natureza do trabalho agrícola possibilita significativos ganhos para a qualidade do ensino e, não menos importante, para viabilizar maior freqüência à escola. 
No entanto, deve-se exercer a liberdade dada em lei com responsabilidade e cuidado. Demasiada ênfase do ensino a peculiaridades da vida agrícola pode não treinar adequadamente o estudante para sua eventual migração para regiões urbanas, ou mesmo, para realizar atividades na zona rural mas fora do setor agrícola. Schultz (1964) ressalta que demasiada ênfase a conhecimentos úteis no curto-prazo pode proporcionar vocações restritas aos jovens.

No pais, os sistemas de ensino são organizados, em regime de colaboração, pela União, Estados e Distrito Federal e Municípios. É atribuição da União coordenar a política nacional de educação, "articulando os diferentes níveis e sistemas e exercendo função normativa, redistributiva e supletiva em relação às demais Instâncias" (Artigo 8, Lei 9394). Organizar, manter e desenvolver os órgãos e instituições oficiais dos seus sistemas de ensino, integrando-os às políticas e planos educacionais da União e dos Estados são, entre outras atribuições, competência dos Estados e Municípios. O ensino fundamental deve ser prioridade dos municípios, enquanto o ensino médio dos Estados.

Não é estranho, portanto, que os estabelecimentos de ensino municipais e estaduais concentrem a maior parcela das matrículas. Em 1998, das 40,7 milhões de matrículas feitas no ensino fundamental, educação infantil e classes de alfabetização, 18,3 milhões foram realizadas em escolas municipais e 17,7 milhões em escolas estaduais (gráfico 6).

Note, também, a relevância do ensino municipal nas áreas rurais. Em 1998, das 7,47 milhões de matrículas feitas no ensino fundamental, educação infantil e classes de alfabetização nas zonas rurais, 6,38 milhões foram realizadas nas escolas municipais (gráfico 7). O artigo 69 da Lei 9394, determina que estados e municípios apliquem, anualmente, nunca menos de $25 \%$ da receita resultante de impostos na manutenção e desenvolvimento do ensino público. 


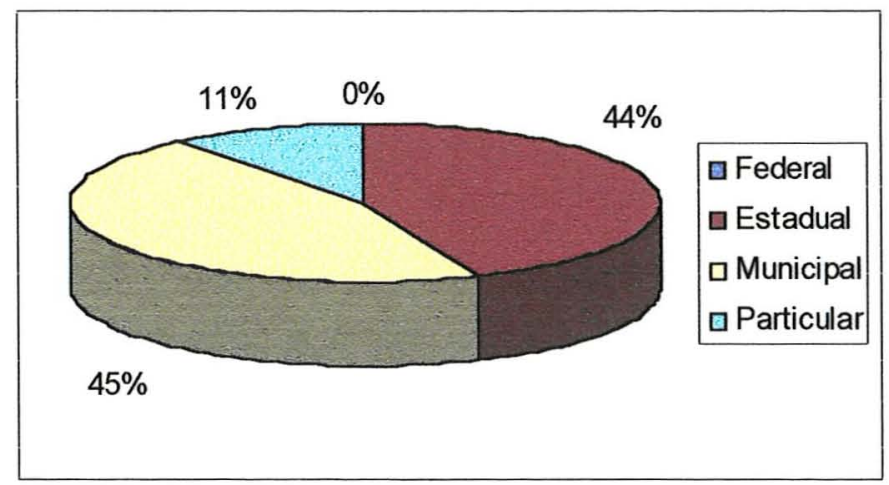

Fonte: MEC/INEP - Instituto Nacional de Estudos e Pesquisas Educacionais

Gráfico 6- Matrículas no ensino fundamental, educação infantil e classes de alfabetização por dependência administrativa no Brasil, 1998.

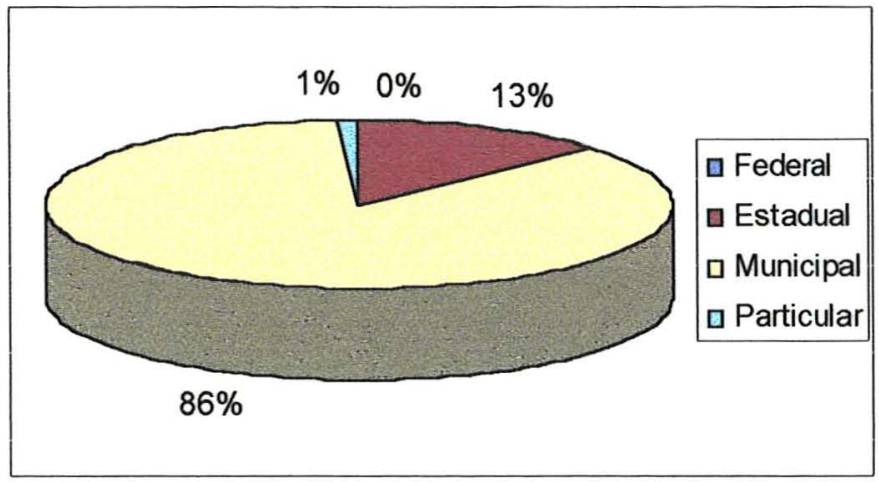

Fonte: MEC/INEP

Gráfico 7- Matrículas no ensino fundamental, educação infantil e classes de alfabetização por dependência administrativa, zonas rurais no Brasil, em 1998.

A qualidade do ensino oferecido no estabelecimento de ensino rural é ponto de preocupação. Do total de matrículas efetuadas em 1998 em instituições de educação infantil, ensino regular e classes de alfabetização, 18 \% foram feitas em áreas rurais, áreas estas que detém $58 \%$ dos estabelecimentos de ensino da educação básica. Tais 
números a primeira vista são animadores, mas na realidade apenas retratam as dificuldades que o ensino rural enfrenta.

Não é estranho que as áreas rurais necessitem de um maior número de pequenos estabelecimentos de ensino, dado que, como citado anteriormente, a densidade populacional no campo é muito menor que nas áreas urbanas. As distâncias entre residências nas regiões rurais são muito maiores que nas cidades.

No entanto, mesmo com maior número de estabelecimentos, o número de docentes exercendo atividades nas salas de aula é menor nas áreas rurais. São 2,1 milhões de docentes em exercício nas classes de alfabetização, educação infantil e ensino regular no Brasil sendo 347,9 mil nas zonas rurais, ou 16,5 \%. A qualidade de formação desses docentes também é inferior nas áreas rurais, quando em comparação com a qualidade dos docentes no país como um todo (gráficos 8 e 9).

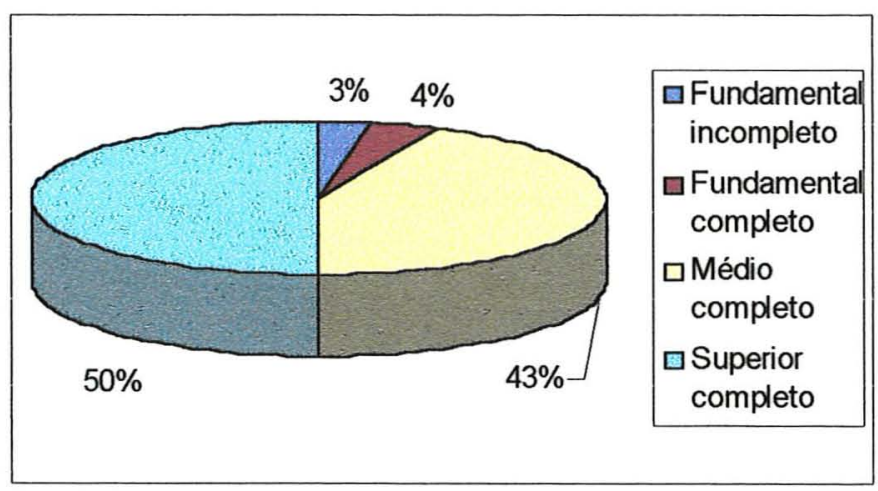

Fonte: MEC/INEP

Gráfico 8- Grau de formação dos docentes em atividade no Brasil nas classes de alfabetização, educação infantil e ensino regular, 1998. 


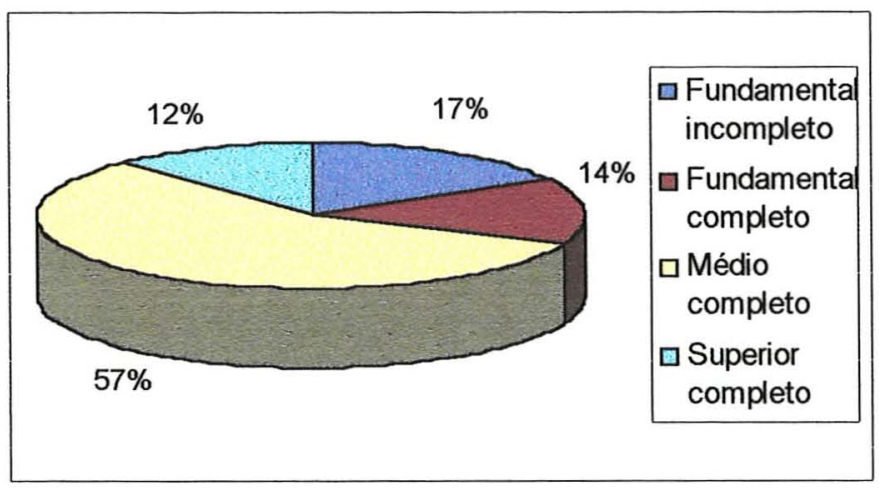

Fonte: MEC/INEP

Gráfico 9- Grau de formação dos docentes em atividade no Brasil nas classes de alfabetização, educação infantil e ensino regular, áreas rurais, 1998.

Professores inadequadamente treinados nas escolas rurais comprometem a qualidade do ensino oferecido. Parcela expressiva dos professores das escolas rurais, $17 \%$, sequer completou o ensino fundamental. Portanto, preparar e treinar melhor esses docentes deve ser parte integrante da estratégia de política educacional.

Analisando a situação do ensino superior no Brasil, percebe-se nitidamente a preferência por profissões nas áreas de ciências sociais e humanas. Profissões voltadas para engenharia e tecnologia ocupam pouco destaque, enquanto a formação em ciências agrárias é muito pequena. Do total de 254,4 mil alunos que concluíram o curso superior em 1995, 169,7 mil eram das áreas de ciências sociais e humanas (gráfico 10).

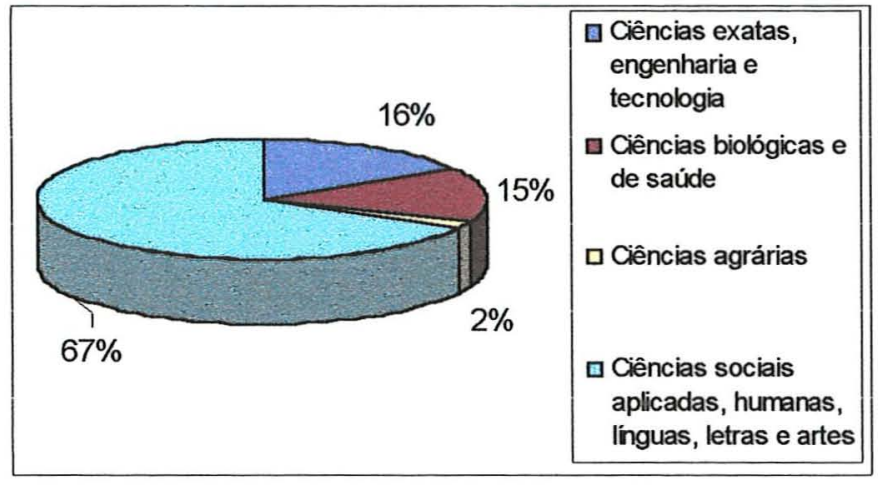

Fonte: MEC/INEP

Gráfico 10- Concluintes dos cursos superiores por área de conhecimento no Brasil, 1995 
A alocação de pessoas capacitadas e bem treinadas nas áreas de engenharia e tecnologia está diretamente relacionada com crescimento econômico, enquanto excessivo número de profissionais na área jurídica pode reduzir a taxa de crescimento econômico do país (Murphy, Shleifer e Vishny, 1991). A capacidade de desenvolvimento tecnológico da nação, diretamente responsável pelo aumento da renda per capita no médio e longo prazos, depende de profissionais nas áreas tecnológicas. Países com excessivo volume de despesas governamentais tendem a apresentar menor crescimento econômico (Barro, 1991) e a atrair maior número de profissionais para setores burocráticos e menos produtivos (Murphy, Shleifer e Vishny, 1991).

No caso do setor agrícola, o pequeno número de graduandos em ciências agrárias reduz o número de pessoas capacitadas para desenvolver pesquisa e extensão nesta área. Um reduzido corpo de pesquisadores dificultará a geração e difusão de tecnologia e, consequentemente, comprometerá o ritmo de desenvolvimento das áreas rurais.

\subsubsection{A Questão dos Custos da Educação no Brasil}

Os custos da educação são elevados, variando significativamente entre os estados e conforme o nível de ensino em curso pelo aluno. Considerando a média nacional de gastos por aluno ao ano, a educação superior é a mais cara ao Estado. Gasta-se, em média, $R \$ 7.321,00$ por aluno/ano no ensino superior. O Ensino Fundamental é o nível educacional que recebe o menor investimento por aluno, $\mathrm{R} \$ 460,00$ ao ano. No Ensino Médio o Estado investe $\mathbf{R} \$ 682,00$ ao ano por aluno, enquanto na educação de crianças de 0 a 6 anos gasta-se $R \$ 557,00$ ao ano.

$\mathrm{O}$ atendimento educacional da população também varia muito entre os diferentes estados. A estrutura de partilha dos recursos tributários do país influencia a capacidade de financiamento que cada estado possui. O Maranhão gasta na educação de crianças de 0 a 6 anos R\$191,00 por aluno/ano, enquanto em São Paulo o gasto é de R\$1299,00. 
No Ensino Fundamental os Estados com menor gasto por aluno ao ano são o Pará, R\$ 216,00 , e o Maranhão, R $\$ 223,00$. Na outra ponta o Distrito Federal gasta $R \$ 1.635,00$ por aluno/ano e São Paulo R $\$ 663,00$.

Esses números não podem ser vistos simplesmente como falta de prioridade da educação. As diferenças regionais refletem principalmente as diferenças econômicas existentes entre os estados. No Maranhão, por exemplo, o PIB per capita no ano de 1995 foi de $R \$ 1.283,75$, enquanto em São Paulo o valor correspondente foi de $R \$ 6.820,30$. Essas mesmas diferenças econômicas tornam diferentes o custo de vida e os salários pagos aos professores e demais profissionais da educação (Quadros 5,6 e 7). 


\begin{tabular}{|c|c|c|c|}
\hline \multirow[t]{2}{*}{ Regiões e Estados } & \multicolumn{3}{|c|}{ Ensino Fundamental } \\
\hline & Governo Estadual & Governo Municipal & Total \\
\hline Norte & 350 & 209 & 302 \\
\hline Acre & 728 & 362 & 611 \\
\hline Rondônia & 490 & 134 & 365 \\
\hline Amazonas & 296 & 241 & 278 \\
\hline Roraima & 459 & 1782 & 498 \\
\hline Pará & 261 & 144 & 216 \\
\hline Amapá & 431 & 1095 & 522 \\
\hline Tocantins & 458 & 345 & 420 \\
\hline Nordeste & 357 & 211 & 278 \\
\hline Maranhão & 373 & 146 & 223 \\
\hline Piauí & 462 & 177 & 303 \\
\hline Ceará & 553 & 236 & 361 \\
\hline Rio Grande do Norte & 337 & 332 & 335 \\
\hline Paraiba & 250 & 230 & 240 \\
\hline Pernambuco & 271 & 226 & 248 \\
\hline Alagoas & 496 & 195 & 296 \\
\hline Sergipe & 548 & 277 & 426 \\
\hline Bahia & 298 & 209 & 253 \\
\hline Sudeste & 581 & 696 & 608 \\
\hline Minas Gerais & 538 & 606 & 554 \\
\hline Espírito Santo & 410 & 881 & 528 \\
\hline Rio de Janeiro & 909 & 320 & 546 \\
\hline São Paulo & 574 & 1390 & 663 \\
\hline Sul & 455 & 658 & 535 \\
\hline Paraná & 477 & 579 & 525 \\
\hline Santa Catarina & 422 & 770 & 520 \\
\hline Rio Grande do Sul & 455 & 712 & 555 \\
\hline Centro-Oeste & 440 & 499 & 457 \\
\hline Mato Grosso do Sul & 466 & 630 & 529 \\
\hline Mato Grosso & 637 & 684 & 652 \\
\hline Goiás & 280 & 341 & 300 \\
\hline Distrito Federal & 528 & - & 528 \\
\hline $\begin{array}{l}\text { Distrito Federal (incluindo Recursos } \\
\text { Gov. Federal) }\end{array}$ & 1635 & - & 1635 \\
\hline Brasil & 502 & 418 & 460 \\
\hline
\end{tabular}

Fonte: IPEA/DISOC

Obs.: os gastos seguem o critério da origem dos recursos que identifica qual a esfera de governo financia o dispêndio

Quadro 5 - Gasto anual médio por aluno no Ensino Fundamental por Região e Estados do Brasil: 1995 (Em R\$ 1,00) 


\begin{tabular}{|c|c|c|c|c|}
\hline \multirow[t]{2}{*}{ Regiões e Estados } & \multicolumn{4}{|c|}{ Ensino Médio } \\
\hline & $\begin{array}{l}\text { Governo } \\
\text { Federal }\end{array}$ & $\begin{array}{l}\text { Governo } \\
\text { Estadual }\end{array}$ & $\begin{array}{l}\text { Governo } \\
\text { Municipal }\end{array}$ & Total \\
\hline Norte & 5479 & 347 & - & 499 \\
\hline Acre & - & 692 & - & 692 \\
\hline Rondônia & - & 540 & - & 590 \\
\hline Amazonas & 3881 & 290 & - & 466 \\
\hline Roraima & 5957 & 371 & - & 851 \\
\hline Pará & 6279 & 263 & - & 455 \\
\hline Amapá & - & 382 & - & 390 \\
\hline Tocantins & 10145 & 515 & - & 575 \\
\hline Nordeste & 4079 & 367 & 584 & 502 \\
\hline Maranhão & 3631 & 392 & - & 420 \\
\hline Piauí & 2183 & 451 & - & 611 \\
\hline Ceará & 4719 & 567 & - & 627 \\
\hline Rio Grande do Norte & 5269 & 337 & - & 552 \\
\hline Paraiba & 5413 & 305 & - & 580 \\
\hline Pernambuco & 2622 & 279 & - & 356 \\
\hline Alagoas & 4427 & 520 & - & 964 \\
\hline Sergipe & 4833 & 577 & - & 786 \\
\hline Bahia & 6973 & 321 & 584 & 466 \\
\hline Sudeste & 4881 & 580 & 1084 & 780 \\
\hline Minas Gerais & 5628 & 590 & - & 1368 \\
\hline Espírito Santo & 4096 & 392 & - & 559 \\
\hline Rio de Janeiro & 5110 & 890 & - & 1050 \\
\hline São Paulo & 3211 & 529 & 1084 & 550 \\
\hline Sul & 3414 & 486 & 428 & 591 \\
\hline Paraná & 1906 & 501 & 690 & 555 \\
\hline Santa Catarina & 5895 & 515 & - & 697 \\
\hline Rio Grande do Sul & 4182 & 449 & 418 & 584 \\
\hline Centro-Oeste & 4576 & 487 & - & 808 \\
\hline Mato Grosso do Sul & - & 550 & - & 529 \\
\hline Mato Grosso & 4358 & 737 & - & 930 \\
\hline Goiás & 4700 & 319 & - & 444 \\
\hline Distrito Federal & 4740 & 542 & - & 1657 \\
\hline $\begin{array}{l}\text { Distrito Federal (incluindo Recursos } \\
\text { Gov. Federal) }\end{array}$ & - & 1692 & - & 1692 \\
\hline Brasil & 4495 & 522 & 1297 & 682 \\
\hline
\end{tabular}

Fonte: IPEADISOC

Obs.: os gastos seguem o critério da origem dos recursos que identifica qual a esfera de governo financia 0 dispêndio

Quadro 6 - Gasto anual médio por aluno no Ensino Médio por Região e Estados do Brasil: 1995 (Em R\$ 1,00) 


\begin{tabular}{|c|c|c|c|c|}
\hline \multirow[t]{2}{*}{ Regióes e Estados } & \multicolumn{4}{|c|}{ Ensino Médio } \\
\hline & $\begin{array}{l}\text { Governo } \\
\text { Federal }\end{array}$ & $\begin{array}{l}\text { Governo } \\
\text { Estadual }\end{array}$ & $\begin{array}{l}\text { Governo } \\
\text { Municipal }\end{array}$ & Total \\
\hline Norte & 6859 & 1118 & - & 6571 \\
\hline Acre & 10609 & - & - & 10609 \\
\hline Rondônia & 4436 & - & - & 4436 \\
\hline Amazonas & 6766 & - & - & 6766 \\
\hline Roraima & 6184 & - & - & 6184 \\
\hline Pará & 7291 & 1118 & - & 6520 \\
\hline Amapá & 2155 & - & - & 2155 \\
\hline Tocantins & - & - & - & - \\
\hline Nordeste & 8024 & 1495 & - & 5230 \\
\hline Maranhão & 9315 & 2538 & - & 6215 \\
\hline Piauí & 6424 & - & - & 6424 \\
\hline Ceará & 8785 & - & - & 8785 \\
\hline Rio Grande do Norte & 11002 & 3561 & - & 8583 \\
\hline Paraíba & 9010 & 1944 & - & 6495 \\
\hline Pernambuco & 7128 & 2692 & - & 4669 \\
\hline Alagoas & 9352 & 3818 & - & 8539 \\
\hline Sergipe & 5527 & - & - & 5527 \\
\hline Bahia & 6392 & 902 & - & 3698 \\
\hline Sudeste & 10936 & 5594 & 2764 & 7423 \\
\hline Minas Gerais & 10346 & 1003 & - & 8502 \\
\hline Espírito Santo & 7532 & 1046 & - & 6503 \\
\hline Rio de Janeiro & 11093 & 11666 & - & 11163 \\
\hline São Paulo & 20371 & 4408 & 2764 & 4682 \\
\hline Sul & 10099 & 4476 & - & 5745 \\
\hline Paraná & 8647 & 4023 & $=$ & 4970 \\
\hline Santa Catarina & 8202 & 8714 & - & 2909 \\
\hline Rio Grande do Sul & 11621 & - & - & 11621 \\
\hline Centro-Oeste & 8673 & 1507 & - & 6843 \\
\hline Mato Grosso do Sul & 7180 & - & - & 7180 \\
\hline Mato Grosso & 7672 & 3169 & - & 6834 \\
\hline Goiás & 6549 & 941 & - & 3489 \\
\hline Distrito Federal & 11892 & - & - & 11892 \\
\hline Brasil & 11072 & 4004 & 1082 & 7321 \\
\hline
\end{tabular}

Fonte: IPEA/DISOC

Obs.: os gastos seguem o critério da origem dos recursos que identifica qual a esfera de governo financia o dispêndio

Quadro 7 - Gasto anual médio por aluno no Ensino Superior por Região e Estados do Brasil: 1995 (Em R\$ 1,00) 
Os valores apresentados nos quadros 5,6 e 7, destacam a menor capacidade de investimento das regiões Norte e Nordeste quando comparadas às demais regiões do país. Os estados dessas regiões, apesar de, em valores absolutos, gastarem menos com educação que os estados da região Centro-Sul, analisando os valores como percentagem do PIB, percebe-se que seu padrão de gastos não significa menor prioridade à educação.

Com efeito, os estados das regiões Norte e Nordeste investem maior parcela dos seus recursos em educação que os estados das regiões Sudeste e Sul. No Nordeste 5,7\% do PIB são gastos em educação, no Norte este valor é 4,6\%. Por outro lado, 3,5\% do PIB dos estados da região Sudeste são aplicados em educação. Na região Sul este valor é $3,6 \%$ (ver quadro 8 ). 


\begin{tabular}{|c|c|c|c|c|c|c|c|c|c|}
\hline \multirow{2}{*}{$\begin{array}{l}\text { Regióes e } \\
\text { Estados }\end{array}$} & \multirow{2}{*}{$\begin{array}{c}\text { Gasto } \\
\text { Educação } \\
\text { (área de } \\
\text { atuação) }\end{array}$} & \multicolumn{3}{|c|}{ Gastos Afins } & \multirow{2}{*}{\begin{tabular}{|c|} 
Gasto \\
Educação + \\
Gastos \\
Afins \\
Total \\
$(\mathrm{e}=\mathrm{a}+\mathrm{b}+\mathrm{c}+\mathrm{d})$
\end{tabular}} & \multirow{2}{*}{$\begin{array}{r}\text { PIB } \\
\text { (f) }\end{array}$} & \multirow[t]{2}{*}{$a / f$} & \multirow[t]{2}{*}{$\mathrm{e} / \mathrm{f}$} & \multirow[t]{2}{*}{$\mathrm{a} / \mathrm{e}$} \\
\hline & & $\begin{array}{l}\text { Beneficios } \\
\text { Servidores } \\
\text { (b) }\end{array}$ & $\begin{array}{c}\text { Manutençăa } \\
\text { Hosp. } \\
\text { Ensino(c) }\end{array}$ & $\begin{array}{l}\text { Alimentação } \\
\text { Escolar (d) }\end{array}$ & & & & & \\
\hline Norte & $1.499,0$ & 218,8 & 19,7 & 58,6 & $1.796,1$ & $32.558,5$ & 4,6 & 5,5 & 0,83 \\
\hline Acre & 121,8 & 19,1 & - & 2,3 & 143,2 & $1.463,3$ & 8,3 & 9,8 & 0,85 \\
\hline Rondônia & 140,7 & 5,6 & - & 7,0 & 153,3 & $4.342,4$ & 3,2 & 3,5 & 0,92 \\
\hline Amazonas & 368,5 & 64,5 & 13,8 & 12,3 & 459,1 & $8.827,2$ & 4,2 & 5,2 & 0,80 \\
\hline Roraima & 55,2 & 1,2 & - & 0,8 & 57,2 & $7.63,6$ & 7,2 & 7,5 & 0,97 \\
\hline Pará & 572,9 & 118,3 & 5,9 & 28,1 & 725,1 & $14.855,1$ & 3,9 & 4,9 & 0,79 \\
\hline Amapá & 71,5 & 5,1 & - & 1,2 & 77,7 & $1.175,5$ & 6,1 & 6,6 & 0,92 \\
\hline Tocantins & 168,4 & 5,2 & - & 6,9 & 180,4 & $1.131,3$ & 14,9 & 15,9 & 0,93 \\
\hline Nordeste & $4.843,5$ & 1015,2 & 72,5 & 220,5 & $6.151,7$ & $82.277,4$ & 5,7 & 7,2 & 0,79 \\
\hline Maranhão & 470,9 & 63,3 & 3,4 & 30,1 & 567,7 & $6.640,0$ & 7,1 & 8,5 & 0,83 \\
\hline Piauí & 294,6 & 51,1 & 0,8 & 16,2 & 362,7 & $3.232,0$ & 9,1 & 11,2 & 0,81 \\
\hline Ceará & 709,4 & 150,6 & 9,3 & 26,1 & 895,3 & $11.742,6$ & 6,0 & 7,6 & 0,79 \\
\hline R. G. do Norte & 368,0 & 89,1 & 13,2 & 13,9 & 484,1 & $6.092,0$ & 6,0 & 7,9 & 0,76 \\
\hline Paraíba & 448,2 & 125,8 & 32,0 & 15,2 & 621,1 & $4.976,5$ & 9,0 & 12,5 & 0,72 \\
\hline Pernambuco & 685,7 & 230,3 & 6,3 & 35,0 & 957,3 & $15.430,4$ & 4,4 & 6,2 & 0,72 \\
\hline Alagoas & 250,3 & 65,9 & 5,3 & 8,9 & 330,4 & $3.931,5$ & 6,4 & 8,4 & 0,76 \\
\hline Sergipe & 235,1 & 48,6 & 1,0 & 8,6 & 293,3 & $5.178,2$ & 4,5 & 5,7 & 0,80 \\
\hline Bahia & $1.173,9$ & 190,5 & 1,3 & 66,5 & $1.432,2$ & $28.054,2$ & 4,2 & 5,1 & 0,82 \\
\hline Sudeste & $12.790,5$ & 2857,3 & 233,9 & 214,2 & $16.095,9$ & $370.429,2$ & 3,5 & 4,3 & 0,79 \\
\hline Minas Gerais & $3.222,5$ & 951,1 & 68,3 & 82,0 & $4.324,0$ & $58.339,6$ & 5,5 & 7,4 & 0,75 \\
\hline Espírito Santo & 482,9 & 128,9 & 15,0 & 12,9 & 639,6 & $13.096,7$ & 3,7 & 4,9 & 0,76 \\
\hline Rio de Janeiro & $2.392,1$ & 945,8 & 85,5 & 28,8 & $3.452,2$ & $68.462,0$ & 3,5 & 5,0 & 0,69 \\
\hline São Paulo & $6.693,1$ & 831,5 & 65,1 & 90,5 & $7.680,2$ & $230.530,9$ & 2,9 & 3,3 & 0,87 \\
\hline Sul & $3.914,3$ & 1152,4 & 193,6 & 80,2 & $5.340,5$ & $107.595,7$ & 3,6 & 5,0 & 0,73 \\
\hline Paraná & $1.497,9$ & 345,1 & 64,4 & 36,0 & $1.943,5$ & $39.577,1$ & 3,8 & 4,9 & 0,77 \\
\hline Santa Catarina & 848,6 & 223,5 & 16,7 & 18,2 & $1.107,0$ & $21.063,3$ & 4,0 & 5,3 & 0,77 \\
\hline R.G. do Sul & $1.567,9$ & 583,7 & 112,5 & 25,9 & $2.290,0$ & $46.955,3$ & 3,3 & 4,9 & 0,68 \\
\hline Centro-Oeste & $2.301,4$ & 466,7 & 53,1 & 47,3 & $2.868,5$ & $45.373,5$ & 5,1 & 6,3 & 0,80 \\
\hline M.G. do Sul & 318,5 & 37,9 & 19,7 & 10,4 & 386,4 & $8.127,0$ & 3,9 & 4,8 & 0,82 \\
\hline Mato Grosso & 492,5 & 50,8 & 8,5 & 8,0 & 559,8 & $7.626,0$ & 6,5 & 7,3 & 0,88 \\
\hline Goiás & 452,8 & 157,2 & 15,6 & 21,3 & 646,9 & $14.867,5$ & 3,0 & 4,4 & 0,70 \\
\hline Dist. Federal & $1.037,5$ & 220,8 & 9,3 & 7,7 & $1.275,4$ & $14.753,1$ & 7,0 & 8,6 & 0,81 \\
\hline Não Region. & $1.841,8$ & - & 8,0 & 34,6 & $1.884,4$ & $4.957,2$ & 37,2 & 38,0 & 0,98 \\
\hline Total & 27190,5 & 5710,4 & 580,7 & 655,4 & 34137,0 & $646.191,5$ & 4,2 & 5,3 & 0,80 \\
\hline
\end{tabular}

Fonte: IPEA/DIPOS

Quadro 8 - Gasto público consolidado em educação e o PIB, pela metodologia IPEA agregando gastos de outras áreas (Gasto em Educação Expandido): Brasil, 1995 
Estados e municípios são as esferas governamentais responsáveis pelo financiamento da educação, principalmente no Ensino Fundamental e Médio. Dos R\$ 27.190,00 milhões gastos em educação no Brasil em 1995, coube a União R\$ 6.778,00 milhões, ou $24,9 \%$ do total de gastos, aos estados $\mathrm{R} \$ 12.981,00$ milhões, $47,7 \%$, e aos municípios R $\$ 7.431,00$ milhões, $27,3 \%$.

A União é a grande responsável pelo financiamento do Ensino Superior. Praticamente $80 \%$ dos gastos neste nível educacional são feitos pelo governo federal, o que representa $60 \%$ dos gastos da União com educação. Aproximadamente $60 \%$ dos gastos com Ensino Fundamental e $66 \%$ do Ensino Médio são realizados pelos estados. A educação de crianças de 0 a 6 anos é financiada basicamente com recursos municipais, $75 \%$. Os municípios são importantes também no financiamento do Ensino Fundamental, arcando com cerca de 30\% dos gastos com este nível educacional (Quadro 9).

\begin{tabular}{|c|c|c|c|c|c|c|c|c|c|c|c|}
\hline \multirow{2}{*}{$\begin{array}{l}\text { Niveis e açites de } \\
\text { educaçáa }\end{array}$} & \multicolumn{2}{|c|}{ Federal } & \multicolumn{2}{|c|}{ Estadual } & \multicolumn{2}{|c|}{ Mimicipal } & \multicolumn{2}{|c|}{ Total } & \multirow[t]{2}{*}{$(\mathrm{a} / \mathrm{d})$} & \multirow[t]{2}{*}{$(b / d)$} & \multirow[t]{2}{*}{$(d d)$} \\
\hline & (a) & $\%$ & (b) & $\%$ & (c) & $\%$ & $(d=a+b+c)$ & $\%$ & & & \\
\hline $\begin{array}{l}\text { Educaçăo de criança de } 0 \\
\text { a } 6 \text { anos }\end{array}$ & 39.827 & 0,6 & 555.546 & $\overline{4,3}$ & 1.833244 & 24,7 & 2.428 .617 & 54,5 & 1,6 & 229 & 75,5 \\
\hline Ensino Fundamental & 1.549 .268 & 22,9 & 8.880 .467 & 68,4 & 4381.081 & 59,0 & 14.810 .816 & 54,5 & 10,5 & 60,0 & 29,6 \\
\hline Ensino Médio & 582.248 & 8,6 & 1912325 & 14,7 & 375.096 & 5,0 & 2.869 .669 & 10,6 & 20,3 & 66,6 & 13,1 \\
\hline Educaça superior & 4.069318 & 60,0 & 957.728 & 7,4 & 101.527 & 1,4 & 5.128 .573 & 18,9 & 79,3 & 18,7 & 20 \\
\hline Pesquisa & 0 & 0 & 287 & 0 & 0 & 0 & 287 & 0 & 0 & 100 & 0 \\
\hline $\begin{array}{l}\text { Ens.Sup. eEduc de joves } \\
\text { eadultos }\end{array}$ & 35.287 & 0,5 & 238.358 & 1,8 & 108.678 & 1,5 & 382.322 & 1,4 & 9,2 & 62,3 & 28,4 \\
\hline Ed Fisica e desporto & 58.020 & 0,9 & 106.216 & 0,8 & 395.787 & 5,3 & 560.023 & 2,1 & 10,4 & 19,0 & 70,7 \\
\hline Educ especial & 37.554 & 0,6 & 79.964 & 0,6 & 48.055 & 0,6 & 165.573 & 0,6 & 22,7 & 48,3 & 29,0 \\
\hline Assistência ao educando & 199.873 & 29 & 250.794 & 19 & 188.086 & 2,5 & 638.753 & 23 & 31,3 & 39,3 & 29,4 \\
\hline $\begin{array}{l}\text { Manutenção ativ. } \\
\text { Administrativa }\end{array}$ & 206.192 & 3,0 & 0 & 0 & 0 & 0 & 206.192 & 0,8 & 100,0 & 0 & 0 \\
\hline Tatal & 6.777 .586 & 100 & 12.981 .685 & 100 & 7.431 .554 & 100 & 27.190 .826 & 100 & 24,9 & 47,7 & 27,3 \\
\hline
\end{tabular}

Fonte: IPEA/DISOC

Obs.: os gastos seguem o critério da origem dos recursos que identifica qual a esfera de governo financia o dispêndio

Quadro 9 - Participação dos gastos dos níveis e ações na área de educação por esfera de governo: 1995 (Em R\$ Mil nominais) 
Note do exposto acima que as regiões com menor capacidade de financiar a educação utilizam menor tecnologia na agricultura, apresentam menor qualidade do ensino oferecido e maior necessidade de investimentos. Para analisar como a educação influencia o desempenho da agricultura nas diferentes regiões é interessante e oportuno detectar se o aumento da educação influencia a produção agrícola de forma diferenciada de acordo com as características regionais.

\subsubsection{O problema e as hipóteses a serem testadas}

As evidencias empíricas apresentadas ilustram a crescente importância da escolaridade no mercado de trabalho. O nível educacional das populações rurais é preocupante, sobretudo ao se considerar a sombria perspectiva, mantida a situação atual, dessas pessoas alcançarem melhores condições de emprego e renda.

Melhorar a educação da população rural provocará por certo impactos no processo de desenvolvimento agrícola. $O$ aumento da escolaridade deve ocasionar aumento do produto agrícola. Esta é a primeira hipótese a ser empiricamente testada: a educação é um fator de influência positiva na produção da agricultura brasileira ?

Como realçado, a educação apresenta dois diferentes efeitos: o direto e o indireto. Não calcular esses dois efeitos pode eventualmente resultar na subestimação do efeito total da educação sobre a produção. A segunda hipótese a ser testada é que o efeito indireto é tão ou mais importante que o próprio efeito direto.

Trabalhos como o de Hopper (1975) evidenciam que, mesmo em comunidades agrícolas que adotam tecnologia tradicional, com mão-de-obra caracterizada por baixa escolarização, a alocação de recursos entre usos alternativos é eficiente. Assim, mesmo quando a educação é muito baixa, como é o caso das comunidades indianas estudadas por Hopper, pode não haver lugar para expressivos ganhos alocativos.

A análise de Schultz (1964), comentando o trabalho de Hopper e outros estudos em comunidades semelhantes, sugere que economias em que a produção agrícola se 
caracteriza pelo uso de fatores "tradicionais" pouco espaço existe para ganhos alocativos. A tecnologia estagnada, característica da agricultura tradicional, garante amplo espaço de tempo para que todas as possibilidades de ganhos técnicos no uso desses fatores sejam exaustivamente experimentados.

Com a modernização das atividades, no entanto, o setor torna-se extremamente dinâmico, com novas técnicas e fatores tornando-se obsoletos antes que todo seu potencial produtivo seja devidamente explorado. Nestas circunstâncias existe maior espaço para ganhos de habilidade alocativa.

Esta constatação sugere que o efeito da educação será tanto maior, quanto mais moderna for a tecnologia adotada na agricultura da região. Considerando que em regiões de tecnologia estagnada, ganhos alocativos são menores ou inexistentes, reduzindo os ganhos provenientes da maior educação, não é estranho constatar que mudanças tecnológicas também afetam o incentivo à busca pela educação.

Se esta premissa estiver correta, as regiões de agricultura moderna devem apresentar efeito alocativo, ou indireto, superior ao efeito direto ou efeito trabalhador. Nas regiões tradicionais, além do efeito total da educação sobre a produção ser mais baixo que nas áreas modernizadas, o efeito direto deve ser mais importante que o efeito indireto.

A terceira hipótese a ser testada é que o efeito indireto do aumento da escolaridade sobre a produção agrícola é maior nas áreas de agricultura moderna, devendo ser maior também o efeito total. Portanto, o efeito total da educação na produção deve ser maior ou menor conforme as características da agricultura das diferentes regiões brasileiras. O produto agrícola das regiões Norte e Nordeste deve responder menos aos aumentos do nível de escolaridade que nas demais regiões do país. 


\section{METODOLOGIA}

\subsection{Modelo teórico e as funções resultantes}

Welch (1970) procurou mostrar que incluir o insumo educação na função de produção da agricultura, como feito no estudo de Griliches (1975), capta apenas o efeito que a educação exerce diretamente sobre a produção, ou seja, mede o efeito trabalhador. Essa abordagem subestima o efeito total da educação sobre a produção.

Welch divide o efeito total em direto e indireto, procurando medir tanto o efeito trabalhador quanto o efeito alocativo.

Considere a seguinte função de produção

$Q=q(X, E)$

Onde $Q$, produto fisico, é uma função da educação, E, e dos outros insumos utilizados na produção, $\mathrm{X}$.

$O$ produto marginal da educação, ou efeito trabalhador, é $\partial \mathrm{q} / \partial \mathrm{E}$. Ele mede a habilidade do trabalhador produzir mais, com aumentos na educação, dados os recursos disponíveis. Neste caso, assume-se ser a produção tecnicamente eficiente.

Em uma função de produção como esta, não há espaço para habilidade alocativa, já que questões de alocação não aparecem na função. Ao incluir educação ou "conhecimento" explicitamente como fator de produção, o conceito de eficiência tecnológica torna-se tautológico. Como ressalta Welch, "produção é tecnicamente 
eficiente se os produtores não sabem que desperdiçam recursos. Se eles desperdiçam recursos mas ignoram que o fazem, a perda é atribuída a falta de conhecimento".

Considere agora as vendas brutas para firmas produzindo mais de um produto. Com duas commodities, tem-se,

$\mathrm{Q}=\mathrm{p}_{1} \mathrm{q}_{1}\left(\mathrm{x}_{1}\right)+\mathrm{p}_{2} \mathrm{q}_{2}\left(\mathrm{x}_{2}\right)$

onde $\mathrm{p}_{1}$ e $\mathrm{p}_{2}$ referem-se aos preços (exógenos ao produtor) das respectivas commodities, $q_{1}$ e $q_{2}$. Ambas commodities são funções do vetor insumos, $X$. A quantidade de $X$ utilizada na produção de $q_{1}$ é denotada por $\mathrm{x}_{1}$ e similarmente para $\mathrm{x}_{2}$. Neste caso, $\mathrm{X}$ é um valor dado, mas a alocação entre os usos competitivos, $\mathrm{x}_{1}$ e $\mathrm{x}_{2}$, não. Note que nesse caso eficiência técnica corresponde a estar sobre a fronteira de transformação do produto, isto é, maximizar $q_{1}$, dado $q_{2}$ e $X$, e não corresponde a maximizar as vendas, $Q$, dado $X$.

Para maximizar Q, tem-se,

$\partial \mathrm{Q} / \partial \mathrm{x}_{1}=\mathrm{p}_{1} \partial \mathrm{q}_{1} / \partial \mathrm{x}_{1}-\mathrm{p}_{2} \partial \mathrm{q}_{2} / \partial \mathrm{x}_{2}=0$

devido às condições de primeira ordem. Maximizar as vendas requer eficiência técnica $\mathrm{e}$, desta forma, o valor do produto marginal de $\mathrm{X}$ deve ser igual entre seus usos competitivos. Considere, no entanto, que nem todos os que utilizam os insumos conhecem igualmente a capacidade produtiva destes, implicando que $\mathrm{Q}$, dado $\mathrm{X}$, não está necessariamente maximizado. Não conhecer a capacidade produtiva do insumo significa que a alocação de $\mathrm{X}$ entre seus usos alternativos é função do conhecimento ou educação, assim, fazendo $x_{1}=x_{1}(E)$, o produto marginal da educação pode ser calculado como,

$\partial \mathrm{Q} / \partial \mathrm{E}=\left[\left(\mathrm{p}_{1} \partial \mathrm{q}_{1} / \partial \mathrm{x}_{1}\right)-\left(\mathrm{p}_{2} \partial \mathrm{q}_{2} / \partial \mathrm{x}_{2}\right)\right] \mathrm{dx} \mathrm{x}_{1} / \mathrm{dE}$

valor que será positivo se a educação aumentar a habilidade alocativa. Então, como ressalta Welch, "quando a educação é tratada como um fator na função de produção das vendas brutas, se a alocação entre alternativas não é uma parte explícita da função, tem- 
se a inferência que o produto marginal da educação inclui ganhos na eficiência alocativa bem como o efeito trabalhador".

Considere, agora, que o valor adicionado, assumindo que há apenas um produto, é expresso como $Q=p q(X, Z)-p_{x} X$, onde $p$, preço do produto e $q$, produto físico, sendo que o valor adicionado é função dos insumos comprados, $\mathrm{X}$, e dos insumos ofertados pela firma ou indústria, $Z$. $O$ preço de $X$ é $p_{x}$, e $p_{x}$ e $p$ são exógenos ao produtor. A produtividade marginal, ou seja, maximizar $Q$ com respeito a $X$, é dada por (eq.20)

$\partial \mathrm{Q} / \partial \mathrm{X}=\mathrm{p}(\partial \mathrm{q} / \partial \mathrm{x})-\mathrm{p}_{\mathrm{x}}=0$

em equilíbrio o valor do produto marginal de $X$ deve ser igual ao seu preço. Note que, quando $Q$ é maximizado com respeito a $X$, o valor adicionado passa a ser função apenas de $Z$. Assumindo, novamente, que a quantidade comprada de $X$ é função da educação, tem-se, neste caso, que o produto marginal da educação é dado por,

$\partial \mathrm{Q} / \partial \mathrm{E}=\left[(\mathrm{p} \partial \mathrm{q} / \partial \mathrm{x})-\mathrm{p}_{\mathrm{x}}\right] \mathrm{dX} / \mathrm{dE}$

Portanto, na função de produção de valor adicionado, considerando $X$ como variável explanatória, implica que um produto marginal positivo denota subutilização dos insumos e o oposto para produto marginal negativo. Alternativamente, ao se utilizar E como variável explícita no lugar de $\mathrm{X}$, o produto marginal da educação irá refletir as relações entre $\mathrm{X}$ e $\mathrm{E}$ mostrando as perdas e ganhos alocativos resultantes.

Assim, ao estimar funções de valor adicionado com múltiplos produtos, especificando a quantidade ofertada de insumos, $Z$, mas não a alocação entre usos alternativos competitivos, e se os insumos comprados são omitidos, o produto marginal da educação irá conter três elementos: (1) efeito trabalhador; (2) seleção da quantidade de outros insumos; e (3) alocação desses insumos entre suas alternativas.

Considere a função de produção de valor adicionado na qual dois insumos são produzidos, $q_{1}$ e $q_{2}$, os quais são eles próprios função de três insumos: educação, $E$; outros insumos ofertados pela firma, $Z$; e insumos comprados, $X$. Os preços dos respectivos produtos são dados por $\mathrm{p}_{1}$ e $\mathrm{p}_{2}$, enquanto $\mathrm{p}_{\mathrm{x}}$ é o preço de $\mathrm{X}$. Tem-se 


$$
\begin{gathered}
Q=p_{1} q_{1}\left(x_{1}, z_{1}, E_{1}\right)-p_{2} q_{2}\left(x_{2}, z_{2}, E_{2}\right)-p_{x} X \\
\text { Onde, } E=E_{1}+E_{2}, Z^{o}=z_{1}+z_{2}, X=x_{1}+x_{2} ; e \\
1=d E_{1} / d E+d E_{2} / d E, 0=d z_{1} / d E+d z_{2} / d E, e d X / d E=d x_{1} / d E+d x_{2} / d E
\end{gathered}
$$

Considere valor adicionado como função das quantidades de educação e insumos ofertados, $Q=f\left(E, Z^{\circ}\right)$; o produto marginal da educação é, portanto,

$$
\begin{aligned}
\partial \mathrm{f} / \partial \mathrm{E}= & \left(\mathrm{p}_{2} \partial \mathrm{q}_{2} / \partial \mathrm{E}\right)+\left(\mathrm{p}_{1} \partial \mathrm{q}_{1} / \partial \mathrm{E}-\mathrm{p}_{2} \partial \mathrm{q}_{2} / \partial \mathrm{E}\right) \mathrm{dE_{1 }} / \mathrm{dE}+\left(\mathrm{p}_{1} \partial \mathrm{q}_{1} / \partial \mathrm{z}-\mathrm{p}_{2} \partial \mathrm{q}_{2} / \partial \mathrm{z}\right) \mathrm{dz} / \mathrm{dE} \\
& +\left(\mathrm{p}_{1} \partial \mathrm{q}_{1} / \partial \mathrm{x}-\mathrm{p}_{2} \partial \mathrm{q}_{2} / \partial \mathrm{x}\right) \mathrm{dx_{1 }} / \mathrm{dE}+\left(\mathrm{p}_{2} \partial \mathrm{q}_{2} / \partial \mathrm{x}-\mathrm{p}_{\mathrm{x}}\right) \mathrm{dE} / \mathrm{dE}
\end{aligned}
$$

Note que o primeiro termo, à direita do sinal de igualdade, na equação 23 , refere-se ao valor do produto marginal da educação, efeito trabalhador; os três termos seguintes referem-se aos ganhos na alocação dos respectivos fatores, educação, insumos ofertados, e insumos comprados, eficientemente alocados entre seus usos alternativos; e, o último termo é o ganho alocativo oriundo da escolha "correta" da quantidade comprada de insumos, $\mathrm{X}$.

Utilizando o argumento de Welch (1970), Patrick \& Kehrberg (1975) sugerem considerar os efeitos direto e indireto da educação na produção agrícola a partir da função de produção tradicional ${ }^{17}$,

$$
Q=f(X, E)
$$

onde o valor do produto, $\mathrm{Q}$, é função dos serviços dos fatores, $\mathrm{X}$, e da educação $\mathrm{E}$. Sendo que, a educação afeta a escolha dos tipos e quantidade dos recursos, ou seja

$X=g(E)$

Chega-se a,

$\mathrm{dQ} / \mathrm{dE}=\partial \mathrm{Q} / \partial \mathrm{E}+\partial \mathrm{Q} / \partial \mathrm{X} \cdot \mathrm{dX} / \mathrm{dE}$

\footnotetext{
${ }^{17}$ Patrick \& Kehrberg ressaltam que o mesmo procedimento pode ser adotado com uma função de valor adicionado parcial em que o valor dos insumos, com preços de mercado bem definidos, fosse subtrádo do produto.
} 
Note que o primeiro termo à direita do sinal de igualdade na equação 26 representa o efeito direto da educação na produção, enquanto o segundo termo é o efeito indireto bruto da educação na produção.

Assim, com base nas equações 24 e 25 , pode-se estimar o efeito total da educação na produção. A equação 24 fornece as estimativas de $\partial \mathrm{Q} / \partial \mathrm{X}$ e $\partial \mathrm{Q} / \partial \mathrm{E}$. Enquanto a equação 25 fornece a estimativa $\mathrm{de} \mathrm{dX} / \mathrm{dE}$.

\subsection{Procedimento estatístico ${ }^{18}$}

Patrick \& Kehrberg (1975) sugerem que uma função de produção de valor adicionado, com base na equação 24 , seja estimada a fim de obter a medida empírica do impacto da educação sobre a produção agrícola brasileira. A forma estrutural do modelo a ser estimado é:

$\ln \mathrm{VA}=\alpha+\beta_{1} \ln \mathrm{SERV}+\beta_{2} \ln \mathrm{EDUC} 2+\varepsilon$

onde, o valor adicionado, VA, é função do serviço dos recursos empregados na produção, SERV, e do estoque total de educação do município, EDUC2. Esta equação procura medir o efeito direto da educação.

Uma equação alternativa a esta será estimada considerando os valores per capita das mesmas variáveis, ou seja, dividindo as variáveis pelo número de trabalhadores. A variável VAT representa o valor agregado por trabalhador. A variável ST representa o valor per capita dos serviços do capital fornecidos pelos estabelecimentos agrícolas. A variável EDUC representa o número médio de anos de estudo de cada trabalhador do município. A forma deste modelo alternativo é:

$\ln \mathrm{VAT}=\alpha+\beta_{3} \ln \mathrm{ST}+\beta_{4} \ln \mathrm{EDUC}+\varepsilon$

Uma versão da equação 25 , visando medir o efeito indireto da educação sobre a produção agrícola será estimada a seguir. Esta equação auxiliar tem a forma: 
$\ln \mathrm{SERV}=\chi+\phi_{1} \ln \mathrm{EDUC} 2+\mu$

Para o modelo que pondera as variáveis pelo número de trabalhadores, a equação auxiliar apresenta a forma:

$\ln \mathrm{ST}=\chi+\phi_{2} \ln \mathrm{EDUC}+\mu$

Os coeficientes estimados $\beta_{1}$ e $\beta_{3}$ podem ser interpretados como a mudança percentual no valor adicionado, total e per capita, quando mais recursos são disponiveis nos estabelecimentos agrícolas. Portanto, são esperados sinais positivos para estes coeficientes. Os coeficientes estimados $\beta_{2}$ e $\beta_{4}$ podem ser interpretados como a mudança percentual do valor adicionado, total ou per capita, por unidade adicional de educação. Os sinais positivos são esperados para $\beta_{2}$ e $\beta_{4}$, indicando que o aumento da educação aumenta a capacidade produtiva da agricultura.

Os sinais positivos esperados para os coeficientes estimados $\phi_{1}$ e $\phi_{2}$ indicam que a habilidade alocativa do agricultor aumenta com a educação. Note, ainda, que o produto marginal estimado da escolaridade é uma medida, neste caso, do retorno privado na forma de valor adicionado, não incluindo outros retornos possíveis da educação formal.

O método para estimação das equações será o OLS (Ordinary Least Squares). O programa Econometric Views (EVIEWS) será utilizado para a estimação.

\subsection{Dados utilizados}

As unidades de observação são os municípios de todos os estados brasileiros. O Censo Agropecuário e a Contagem Populacional, levantamentos realizados pelo Instituto Brasileiro de Geografia e Estatística (IBGE), são as principais fontes de dados utilizadas. As informações referem-se ao período 1995-96. Áreas metropolitanas sem produção agrícola ou muito próxima de zero foram excluídas.

${ }^{18} \mathrm{O}$ procedimento estatístico adotado é baseado em Patrick \& Kehrberg (1975). 
Valor adicionado: variável VA, foi definida como o valor da produção agrícola municipal, lavoura e animal, menos o valor dos insumos comprados pelos estabelecimentos agrícolas dos municípios, exceto mão-de-obra. $\mathrm{O}$ valor dos insumos corresponde ao total gasto com adubos e corretivos, sementes e mudas, agrotóxicos, medicamento animal, sal, rações, outros alimentos, ovos, sacaria, combustível, eletricidade e outros insumos. A variável VAT corresponde ao Valor Adicionado, VA, dividido pelo total de pessoas ocupadas. Os dados utilizados para o cálculo destas variáveis foram obtidos no Censo Agropecuário 1995/96, do IBGE.

Serviços: A variável SERV foi construída a fim de atribuir valor aos serviços prestados pelos recursos empregados na produção. ST corresponde ao valor da variável SERV dividido pelo total de pessoas ocupadas. Nesta variável, somam-se os valores gastos com salários, cota-parte de parceiros, arrendamento, aluguel de máquinas, gastos com empreitada e transporte. Além desses valores, somaram-se ainda os serviços do capital fixo medidos em termos de juros e depreciação sobre o estoque de máquinas e juros sobre terra e estoque de rebanho.

Utilizou-se a taxa de depreciação de $10 \%$ ao ano sobre as máquinas. A taxa de juros de $6 \%$ para máquinas e rebanho, sob a hipótese que o valor médio da poupança seria alternativa apropriada como valor de referência. Para terra o valor usualmente utilizado nos cálculos de custo de produção, $3 \%$ ao ano, foi adotado.

O valor do estoque de máquinas corresponde ao número de tratores, máquinas para plantio, máquinas para colheita, caminhões e utilitários, obtido no Censo Agropecuário 1995/96 e multiplicado pelo preço médio destes itens no mês de dezembro de 1995. O preço das máquinas e equipamentos foi obtido no IEA (Instituto de Economia Agrícola).

O valor do estoque de rebanho foi calculado com base no preço estadual médio das diferentes categorias de animais, em dezembro de 1995, multiplicado pelo número de cabeças destas categorias conforme informação do Censo Agropecuário. 
A fertilidade do solo, distância dos centros consumidores ou portos de exportação e outras importantes características que influem na aptidão das terras à produção agrícola não devem ser desprezadas quando se procura medir a contribuição da variável terra na produção. A melhor forma encontrada para procurar captar todas estas características prevalecentes nos diferentes estados foi considerar o preço médio de arrendamento por estado. Este preço foi multiplicado pelo total de terra utilizada em lavouras e pastagens nos diferentes municípios para se obter o valor total das terras utilizadas para a produção agrícola.

Os valores utilizados para o calculo das variáveis de valor adicionado e serviços dos fatores foram tomados em Reais (R\$). O mês de referência é dezembro de 1995.

Educação: variável EDUC, foi medida como o valor médio por município dos anos completos de estudo dos chefes de domicílios particulares permanentes, das zonas rurais. Dado fornecido pelo IBGE, Contagem Populacional 1996. O estoque total de educação do município, EDUC 2, foi obtido multiplicando-se o número médio de anos de estudo dos chefes de domicílio pelo total das pessoas ocupadas no município. 


\section{RESULTADOS E DISCUSSÃO}

\subsection{Análise descritiva das estatísticas}

Antes da formulação dos modelos cabe estudar as características descritivas dos dados utilizados. Esta etapa do trabalho é importante para verificar se a base de dados disponível ao estudo é adequada para ser submetida às técnicas de estimação dos modelos. A inspeção gráfica permite verificar se as variáveis realmente apresentam as relações esperadas na teoria. Como se trata de uma análise do tipo cross-section, especial atenção será dada ao estudo da variância com a finalidade de detectar e prevenir possíveis problemas de heterocedasticidade.

O primeiro passo foi "plotar" os valores das variáveis independentes contra a variável dependente em diagramas de dispersão. A inspeção gráfica da figura 1 , permite algumas inferências importantes. Primeiro, foram encontradas fortes relações positivas entre as variáveis independentes e a variável dependente, sem evidências de não linearidade. Resultados que estão de acordo com a teoria. 

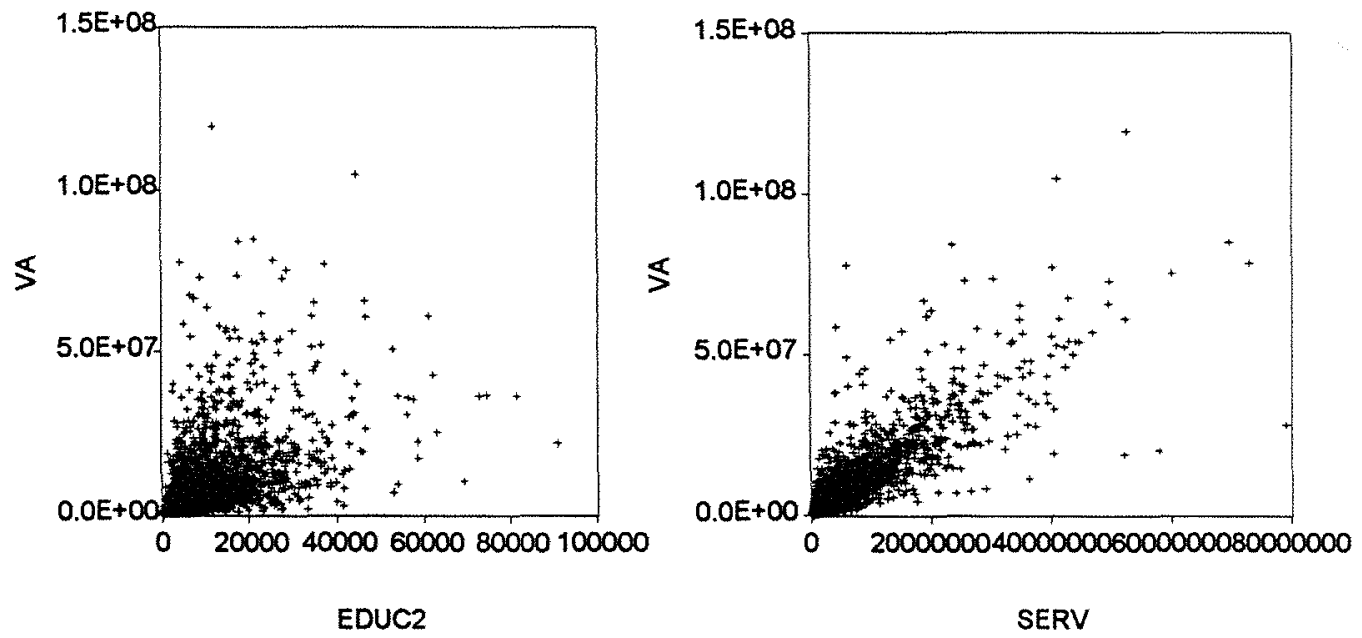

Figura 1 - Variáveis independentes, escolaridade (EDUC2) e recursos fornecidos pelo estabelecimento agropecuário (SERV) versus variável dependente, valor adicionado (VA).

O segundo ponto relevante da análise gráfica consiste no evidente problema de variância não estável, ou seja, nos níveis maiores de educação e dos serviços dos recursos fornecidos pelo estabelecimento agrícola, o valor agregado tende a ser maior, porém com maior dispersão. Esta característica evidencia que a hipótese de homocedasticidade pode estar sendo violada.

$\mathrm{Na}$ presença de heterocedasticidade os estimadores OLS permanecem lineares e não viesados, no entanto, deixam de ser eficientes, ou seja, não há garantia que este estimador apresente a menor variância. Considere um modelo de duas variáveis:

$$
Y_{i}=\beta_{1}+\beta_{2} X_{i}+\mu_{i}
$$

Aplicando a fórmula usual, o estimador OLS de $\beta_{2}$ é:

$$
\beta_{2} \text { estim }=\Sigma x_{i} y_{i} / \Sigma x_{i}^{2}
$$

Sendo que, $x_{i}=(X i-X m e ́ d i o)$ e $y_{i}=(Y i-Y m e ́ d i o ~)$

Considerando a hipótese de homocedasticidade, a fórmula da variância será: 
$\operatorname{var}\left(\beta_{2}\right.$ estim $)=\sigma^{2} / \Sigma x_{i}^{2}$

Mas, na presença de heterocedasticidade, a variância será dada pela expressão:

$$
\operatorname{var}\left(\beta_{2} \text { estim }\right)=\Sigma \mathrm{x}_{\mathrm{i}}^{2}{\sigma_{\mathrm{i}}}^{2} /\left(\Sigma \mathrm{x}_{\mathrm{i}}^{2}\right)^{2}
$$

Note que, se $\sigma_{i}^{2}=\sigma^{2}$ para cada $i$, então as duas fórmulas serão idênticas. Por outro lado, se evidências de heterocedasticidade forem ignoradas e o método OLS padrão for utilizado na regressão, $\operatorname{var}\left(\beta_{2}\right.$ estim) será dada pela expressão 34 e será um estimador viesado da $\operatorname{var}\left(\beta_{2}\right.$ estim) dada pela expressão 33. Assim, o estimador poderá ser sobrestimado ou subestimado, não apresentando mais a mínima variância, ou seja, não há garantias do estimador ser eficiente.

$\mathrm{Na}$ presença de estimadores não eficientes, estabelecer intervalos de confiança e testes de hipóteses, com os usuais testes $\mathrm{t}$ e $\mathrm{F}$, pode acarretar erros. Os resultados encontrados nos testes $t$ e $F$ não serão acurados, ou seja, coeficientes aparentemente estatisticamente não significativos podem ser, na verdade, significativos ${ }^{19}$.

Provavelmente, o problema de heterocedasticidade está sendo causado pela forte assimetria na distribuição das variáveis, conforme mostra a figura 2. Os valores dos coeficientes de assimetria (skewness), "kurtosis" e dos testes Jarque-Bera indicam que a distribuição das variáveis não se aproxima de uma distribuição normal.

\footnotetext{
${ }^{19}$ Ver, por exemplo, Gujarati, 1995.
} 

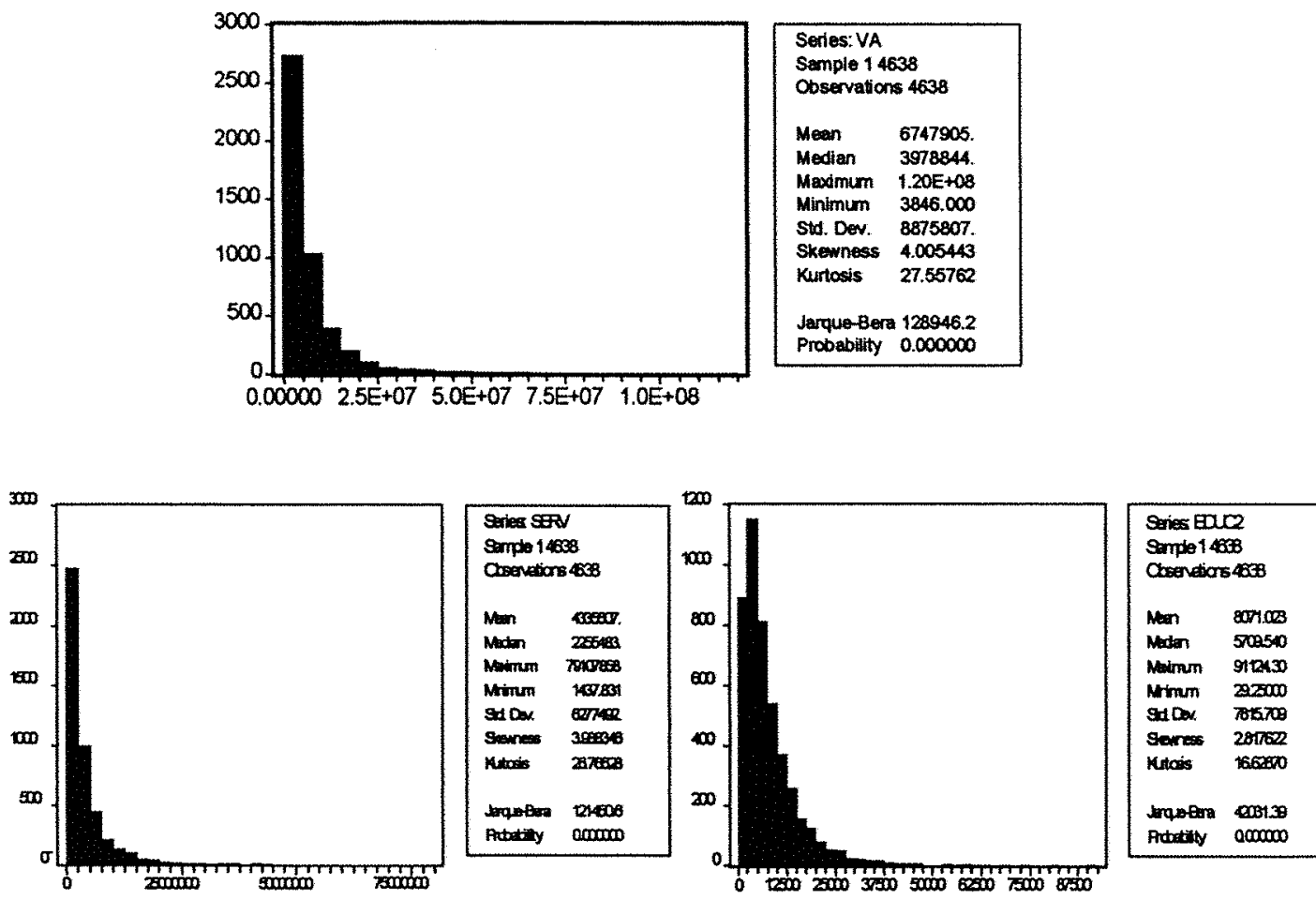

Figura 2 - Histograma da variáveis escolaridade (EDUC2), recursos fornecidos pelo estabelecimento agropecuário (SERV) e valor adicionado (VA).

A maneira de solucionar o problema de variância não estável é utilizar as variáveis na forma de logaritmos. Além de corrigir o problema de heterocedasticidade e melhorar o modelo econométrico, a forma logarítmica traz como benefício adicional a interpretação dos coeficientes estimados como elasticidades médias, o que por certo facilita a análise econômica dos resultados. A figura 3 mostra que utilizando as variáveis na forma de logaritmos resolve-se o problema de variância não estável ${ }^{20}$.

\footnotetext{
${ }^{20}$ Os mesmos testes foram realizados para os dados per capita com resultados semelhantes.
} 

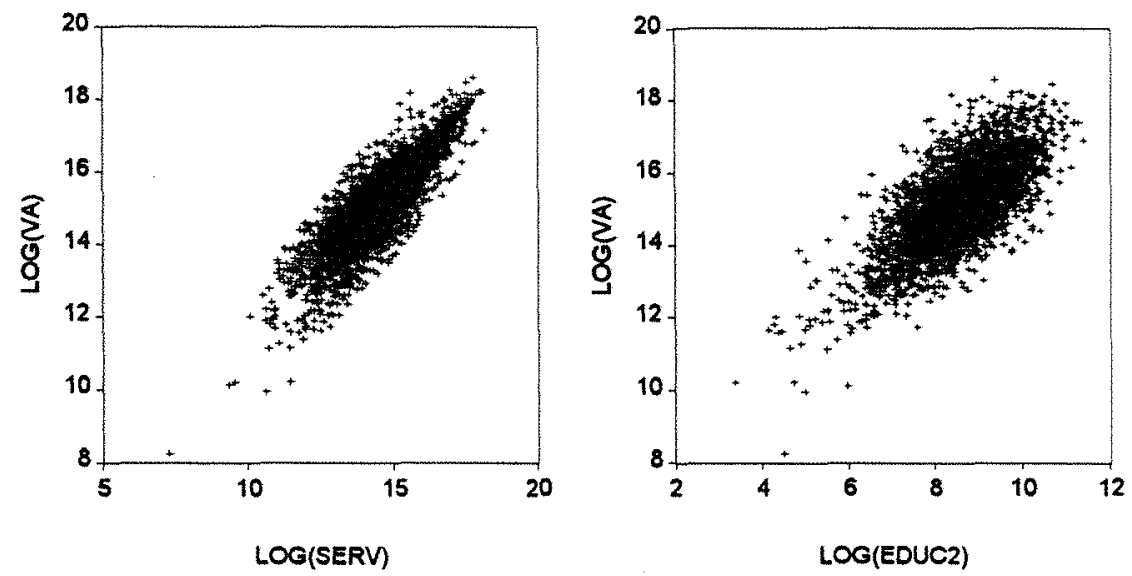

Figura 3 - Variáveis independentes, escolaridade (EDUC2) e recursos fornecidos pelo estabelecimento agropecuário (SERV) versus variável dependente, valor adicionado (VA), na forma logarítmica.

Note, ademais, pela figura 4, que a transformação logarítmica reduz significativamente a assimetria da distribuição. $\mathrm{O}$ indicador de assimetria (skewness) se aproxima de zero e o valor da "kurtosis" se aproxima de 3, valores característicos da distribuição normal.

O valor encontrado no teste Jarque-Bera de normalidade mostra que a distribuição das variáveis na forma logarítmica se aproxima da distribuição normal. Logo, parece plausível acreditar que, com as variáveis na forma logarítmica, o modelo não deve apresentar problemas de heterocedasticidade. De qualquer forma, testes alternativos serão realizados para checar se há evidências de heterocedasticidade. 

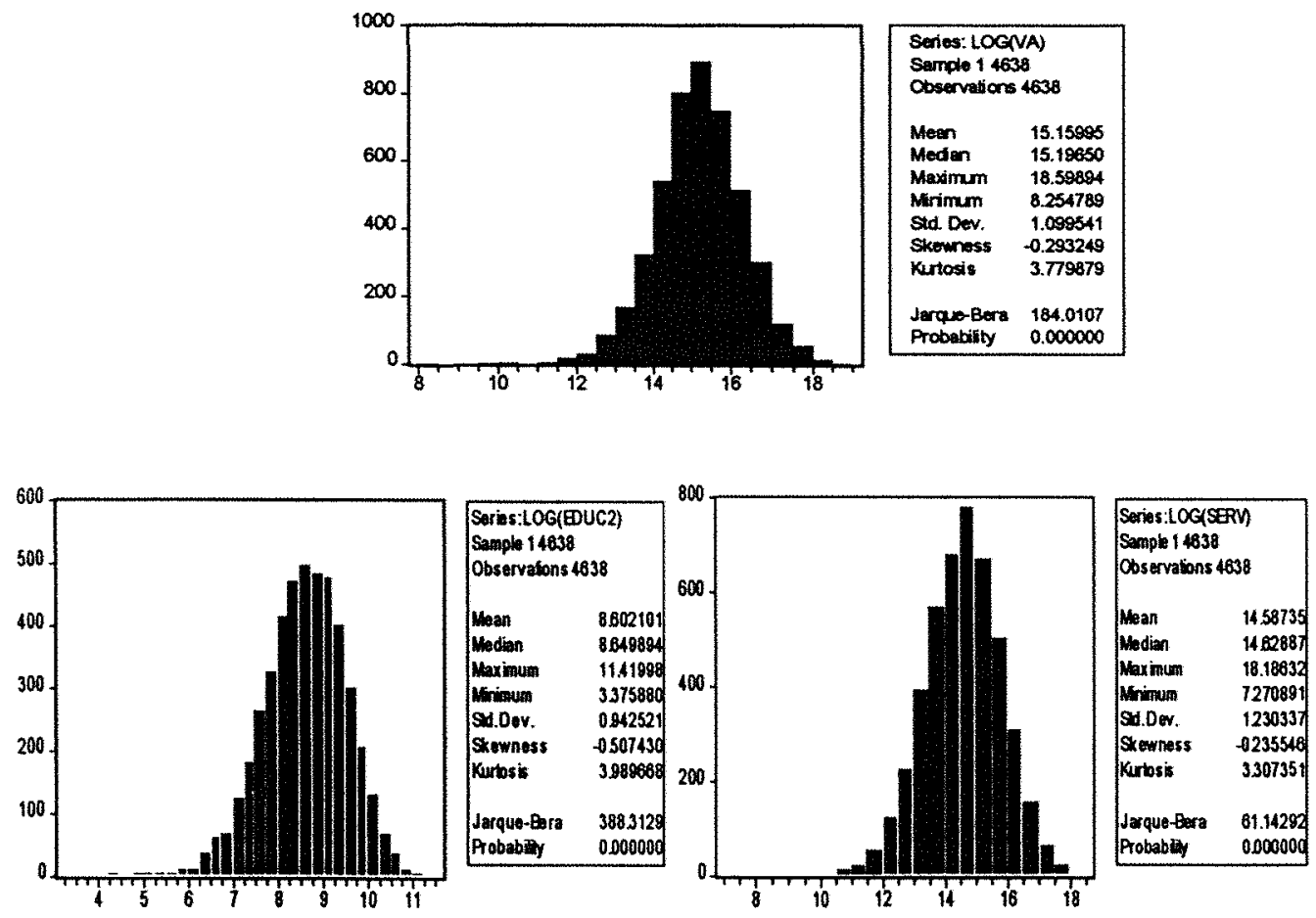

Figura 4 - Histograma da variáveis escolaridade (EDUC2), recursos fornecidos pelo estabelecimento agropecuário (SERV) e valor adicionado (VA), na forma logarítmica.

\subsection{Os resultados do modelo e as equações regionais}

A tabela 1 apresenta as funções de valor adicionado e auxiliares para o Brasil e para as diferentes regiões do país do modelo agregado, enquanto a tabela 2 apresenta os resultados do modelo per capita. As equações regionais foram estimadas procurando detectar se as características da agricultura praticada nas diferentes regiões do país afetam os resultados. 
Tabela 1. Estimativas dos parâmetros e desvios-padrão das funções valor adicionado e das regressões auxiliares na equação Brasil e nas equações regionais.

\begin{tabular}{llllll}
\hline \multicolumn{5}{c}{ Valor Adicionado / Regiões } \\
\hline Variável & Brasil & Norte/Nordeste & Centro-Oeste & Sudeste & Sul \\
& $(\mathrm{n}=4638)$ & $(\mathrm{n}=1750)$ & $(\mathrm{n}=423)$ & $(\mathrm{n}=1434)$ & $(\mathrm{n}=1047)$ \\
Constante & $3,095632^{*}$ & $3,988232^{*}$ & $0,792631^{* *}$ & $1,790006^{*}$ & $3,076949^{*}$ \\
& $(0,083127)$ & $(0,151107)$ & $(0,306055)$ & $(0,169620)$ & $(0,172542)$ \\
SERV & $0,594177^{*}$ & $0,536073^{*}$ & $0,892369^{*}$ & $0,742752^{*}$ & $0,551773^{*}$ \\
& $(0,006858)$ & $(0,012831)$ & $(0,030339)$ & $(0,016465)$ & $(0,015676)$ \\
EDUC2 & $0,394887^{*}$ & $0,392761^{*}$ & $0,135643^{*}$ & $0,279980^{*}$ & $0,462888^{*}$ \\
& $(0,008953)$ & $(0,014267)$ & $(0,040796)$ & $(0,020270)$ & $(0,01893)$ \\
$\mathrm{R}^{2}$ & 0,821733 & 0,753432 & 0,848459 & 0,822757 & 0,848552 \\
& & & Regressão auxiliar & & \\
Constante & $7,973304^{*}$ & $8,640802^{*}$ & $6,604129^{*}$ & $7,430171^{*}$ & $7,830142^{*}$ \\
& $(0.134070)$ & $(0,191380)$ & $(0,371654)$ & $(0,188568)$ & $(0,239291)$ \\
EDUC2 & $0,768888^{*}$ & $0,605378^{*}$ & $1,010631^{*}$ & $0,895031^{*}$ & $0,805964^{*}$ \\
& $(0,015493)$ & $(0,022307)$ & $(0,043230)$ & $(0,022338)$ & $(0,026377)$ \\
$\mathrm{R}^{2}$ & 0,346944 & 0,296439 & 0,564872 & 0,528544 & 0,471861 \\
\hline
\end{tabular}

* indica que o coeficiente é significativo ao nível de $1 \%$

** indica que o coeficiente é significativo ao nível de $5 \%$

As variáveis estão na forma logarítmica e $\mathrm{n}$ representa o número de observações por região 
Tabela 2. Estimativas dos parâmetros e desvios-padrão das funções valor adicionado per capita e das regressão auxiliares na equação Brasil e nas equações regionais.

\begin{tabular}{|c|c|c|c|c|c|}
\hline \multirow[b]{2}{*}{ Variável } & \multicolumn{5}{|c|}{ Valor Adicionado / Regiões } \\
\hline & $\begin{array}{l}\text { Brasil } \\
(n=4638)\end{array}$ & $\begin{array}{l}\text { Norte/Nordeste } \\
(n=1750)\end{array}$ & $\begin{array}{l}\text { Centro-Oeste } \\
(n=423)\end{array}$ & $\begin{array}{l}\text { Sudeste } \\
(n=1434)\end{array}$ & $\begin{array}{l}\text { Sul } \\
(n=1047)\end{array}$ \\
\hline Constante & $\begin{array}{l}2,914459^{*} \\
(0,040552)\end{array}$ & $\begin{array}{l}3,357533^{*} \\
(0,063166)\end{array}$ & $\begin{array}{l}0,717196^{*} \\
(0,214922)\end{array}$ & $\begin{array}{l}2,006729 * \\
(0,107602)\end{array}$ & $\begin{array}{l}3,435324^{*} \\
(0,132316)\end{array}$ \\
\hline ST & $\begin{array}{c}0,631791^{*} \\
(0,007239)\end{array}$ & $\begin{array}{l}0,556729^{*} \\
(0,011583)\end{array}$ & $\begin{array}{l}0,878951^{*} \\
(0,029993)\end{array}$ & $\begin{array}{l}0,758433^{*} \\
(0,017776)\end{array}$ & $\begin{array}{l}0,545767^{*} \\
(0,015296)\end{array}$ \\
\hline EDUC & $\begin{array}{l}0,200651^{*} \\
(0,018255)\end{array}$ & $\begin{array}{l}0,169973^{*} \\
(0,028112)\end{array}$ & $\begin{array}{l}0,501701^{*} \\
(0,101825)\end{array}$ & $\begin{array}{l}0,118959 * * \\
(0,055162)\end{array}$ & $\begin{array}{l}0,305365^{*} \\
(0,069215)\end{array}$ \\
\hline $\mathrm{R}^{2}$ & 0,799588 & 0,626953 & $\begin{array}{l}0,738774 \\
\text { gressão auxilig }\end{array}$ & 0,702187 & 0,568022 \\
\hline Constante & $\begin{array}{l}5,328869^{*} \\
(0,025381)\end{array}$ & $\begin{array}{l}5,316577^{*} \\
(0,029024)\end{array}$ & $\begin{array}{l}6,316572 * \\
(0,164905)\end{array}$ & $\begin{array}{l}5,479332 * \\
(0,067986)\end{array}$ & $\begin{array}{l}6,470611^{*} \\
(0,177609)\end{array}$ \\
\hline EDUC & $\begin{array}{l}1,796780^{*} \\
(0,025990)\end{array}$ & $\begin{array}{l}0,873371 * \\
(0,054160)\end{array}$ & $\begin{array}{l}1,355732^{*} \\
(0,151695)\end{array}$ & $\begin{array}{l}2,019667^{*} \\
(0,062260)\end{array}$ & $\begin{array}{l}0,691416^{*} \\
(0,138341)\end{array}$ \\
\hline $\mathrm{R}^{2}$ & 0,507614 & 0,129499 & 0,159470 & 0,423580 & 0,023346 \\
\hline
\end{tabular}

* indica que o coeficiente é significativo ao nível de $1 \%$

** indica que o coeficiente é significativo ao nivel de $5 \%$

As variáveis estão na forma logarítmica e $\mathrm{n}$ representa o número de observações por região 
Os coeficientes são altamente significativos e os sinais encontrados estão de acordo com o esperado. Os valores dos $\mathrm{R}^{2}$ também são elevados, principalmente em se tratando de uma análise cross section. Mesmo os $\mathrm{R}^{2}$ das equações auxiliares, apesar de menores, são satisfatórios indicando que as variáveis apresentam alto poder explicativo, à exceção do valor encontrado na equação auxiliar da região Sul do modelo per capita

Os valores computados nos testes $\mathrm{F}$ são altamente significativos indicando que os coeficientes de inclinação não são simultaneamente iguais a zero.

Os resultados das tabelas 1 e 2 indicam que os serviços dos recursos fornecidos pelo estabelecimento agrícola foram altamente significativos nas funções de valor agregado per capita e total tanto ao se considerar o país todo como para as suas regiões. O sinal positivo desses coeficientes indica que o valor adicionado na agricultura é influenciado diretamente pela quantidade de recursos fornecida pelo estabelecimento agrícola.

O efeito direto da escolaridade sobre o valor agregado na produção agrícola foi estatisticamente significativo para o país todo e para as regiões. O sinal positivo encontrado indica que a maior escolaridade aumenta o valor agregado per capita e total.

Os recursos fornecidos pelo estabelecimento agrícola são afetados pela educação, devido ao efeito indireto, medido pelas equações auxiliares. Este efeito foi positivo e altamente significativo para o país todo e suas regiões indicando que a maior escolaridade aumenta os recursos produtivos na agricultura.

Estudando cinco diferentes áreas agrícolas da região Leste do Brasil, Patrick \& Kehrberg (1975) encontraram valores de $R^{2}$ menores. Para a equação principal os valores de $\mathrm{R}^{2}$ encontrados por esses autores para as regiões de Paracatu, $\mathrm{C}$ de Castelo, $\mathrm{A}$. São Francisco, Viçosa e Resende foram, respectivamente: 0,58; 0,82; 0,44; 0,62 e 0,55. Nas equações auxiliares os valores por eles encontrados para as mesmas regiões foram: 0,$10 ; 0,009 ; 0,10 ; 0,09$ e 0,20 .

Ainda com referencia ao estudo de Patrick \& Kehrberg (1975), as atividades educacionais não foram, em geral, estatisticamente significativas nas funções de valor 
adicionado. Vale destacar que os coeficientes de escolaridade estimados foram positivos nas duas áreas mais modernas do estudo, e significativo em apenas uma delas, enquanto nas três áreas menos modernas os coeficientes foram negativos e não significativos.

Os recursos fornecidos pelos estabelecimento agrícola foram altamente significativos em praticamente todas as áreas estudas por Patrick \& Kehrberg, com sinais positivos como esperado. Nas equações auxiliares, os sinais dos coeficientes de escolaridade foram positivos e significativos, exceto em uma das áreas.

Conceição \& Araújo (1993) estudaram três macroregiões: Nordeste, composta por Cruz das Almas, Petrolina e Canindé; Centro-Sul, formada pelos produtores de Carazinho, Rondonópolis e São Gabriel d'Oeste; e Ponte Nova/Lajeado. Os $\mathrm{R}^{2}$ da equação principal para essas três regiões foram, respectivamente: 40,$1 ; 46,0$ e 30,6. Para as equações auxiliares os valores do $R^{2}$ foram respectivamente: 8,$6 ; 38,2$ e 23,1 .

Os coeficientes encontrados por esses autores para escolaridade na equação de valor adicionado não foram significativos nas regiões Nordeste e Ponte Nova/Lajeado, sendo que na região Nordeste foi encontrado sinal negativo. Para a região Centro-Sul, o coeficiente da escolaridade foi significativo ao nível de $10 \%$.

Os coeficientes dos recursos fornecidos pelo estabelecimento agropecuário foram significativos em todas as regiões ao nível de $1 \%$. Nas equações auxiliares, o coeficiente da escolaridade foi significativo ao nível de $1 \%$ na região Centro-Sul, $5 \%$ na região Nordeste e não foi significativo na região de Ponte Nova/Lajeado.

Em síntese, os resultados deste estudo em comparação com os demais estudos citados são bastante satisfatórios. Esses bons resultados provavelmente se devem ao fato do estudo cobrir todos os municípios do país. Portanto, incluindo um grande número observações no modelo. 


\subsection{Modelo alternativo utilizando variáveis dummy}

Para tornar mais robusta a análise econométrica, principalmente no que se refere a questão das diferenças regionais, foi estimado um modelo alternativo utilizando variáveis dummy, na tentativa destas captarem as variações que ocorrem regionalmente quanto ao impacto da educação no valor agregado. A vantagem deste modelo alternativo

é que, em uma única equação, captam-se os efeitos da educação e suas diferenças de acordo com a região.

A equação 27 , com a inclusão das variáveis dummy, fica com a seguinte forma:

$\ln (\mathrm{VA})=\alpha+\beta_{1} \ln (\mathrm{SERV})+\beta_{2} \ln (\mathrm{EDUC} 2)+\mathrm{a} 1 \mathrm{DNE}+\mathrm{b} 1 \mathrm{DCO}+\mathrm{c} 1 \mathrm{DSUL}+\mathrm{a} 2$

$\mathrm{DNE} x \ln (\mathrm{SERV})+\mathrm{b} 2 \mathrm{DCO} \times \ln (\mathrm{SERV})+\mathrm{c} 2 \mathrm{DSUL} \times \ln (\mathrm{SERV})+\mathrm{a} 3 \mathrm{DNE} x \ln$

$(\mathrm{EDUC2})+\mathrm{b} 3 \mathrm{DCO} x \ln (\mathrm{EDUC2})+\mathrm{c} 3 \mathrm{DSUL} x \ln (\mathrm{EDUC2})+\varepsilon$

A equação auxiliar 29 fica com a forma:

$\ln (\mathrm{SERV})=\chi+\phi_{1} \ln (\mathrm{EDUC} 2)+\mathrm{d} 1 \mathrm{DNE}+\mathrm{e} 1 \mathrm{DCO}+\mathrm{fl} \mathrm{DSUL}+\mathrm{d} 2 \mathrm{DNE} \mathrm{x} \ln$ $(E D U C 2)+e 2 D C O x \ln (E D U C 2)+f 2 D S U L x \ln (E D U C 2)+\mu$

O mesmo procedimento foi adotado com relação as formas das equações 28 e 30 , do modelo per capita. As tabela 3 e 4 trazem os resultados encontrados nos modelos total e per capita que utilizam as variáveis dummy. 
Tabela 3. Estimativa dos parâmetros e desvios-padrão da função valor adicionado e da regressão auxiliar no modelo com variáveis dummy

\begin{tabular}{|c|c|c|}
\hline & \multicolumn{2}{|c|}{$\begin{array}{l}\text { Variável Dependente VA } \\
(n=4638)\end{array}$} \\
\hline Variáveis Independentes & Coeficiente & Erro Padrão \\
\hline Constante & $1,730118 *$ & 0,159743 \\
\hline SERV & $0,737803 *$ & 0,015508 \\
\hline EDUC2 & $0,295559^{*}$ & 0,019292 \\
\hline DNE & $2,086553^{*}$ & 0,213590 \\
\hline DCO & $-0,937487^{*}$ & 0,356364 \\
\hline DSUL & $1,346831^{*}$ & 0,262521 \\
\hline DNE*LOG(SERV) & $-0,184477^{*}$ & 0,019697 \\
\hline DCO*LOG(SERV) & $0,154566^{*}$ & 0,035180 \\
\hline DSUL*LOG(SERV) & $-0,186029^{*}$ & 0,024469 \\
\hline DNE*LOG(EDUC2) & $0,088526 *$ & 0,023442 \\
\hline DCO*LOG(EDUC2) & $-0,159916^{*}$ & 0,046639 \\
\hline DSUL*LOG(EDUC2) & $0,167329^{*}$ & 0,029416 \\
\hline $\mathrm{R}^{2}$ & 0,831942 & \\
\hline \multicolumn{3}{|c|}{ Equação Auxiliar } \\
\hline Constante & $7,351716^{*}$ & 0,199593 \\
\hline EDUC2 & $0,904191^{*}$ & 0,023634 \\
\hline DNE & $1,299234^{*}$ & 0,262075 \\
\hline $\mathrm{DCO}$ & $-0,747587$ & 0,473657 \\
\hline DSUL & 0,478425 & 0,328704 \\
\hline DNE*LOG(EDUC2) & $-0,298203 *$ & 0,030831 \\
\hline DCO*LOG(EDUC2) & 0,106440 & 0,055272 \\
\hline DSUL*LOG(EDUC2) & $-0,098226^{*}$ & 0,037247 \\
\hline $\mathrm{R}^{2}$ & 0,572525 & \\
\hline
\end{tabular}


Tabela 4. Estimativa dos parâmetros e desvios-padrão da função valor adicionado per capita e da regressão auxiliar no modelo com variáveis dummy.

\begin{tabular}{|c|c|c|}
\hline & \multicolumn{2}{|c|}{$\begin{array}{l}\text { Variável Dependente VAT } \\
\qquad(n=4638)\end{array}$} \\
\hline Variáveis Independentes & Coeficiente & Erro Padrão \\
\hline Constante & $2,043342^{*}$ & 0,100334 \\
\hline ST & $0,753409^{*}$ & 0,016569 \\
\hline EDUC & $0,117618^{* *}$ & 0,051288 \\
\hline DNE & $1,221343^{*}$ & 0,116957 \\
\hline $\mathrm{DCO}$ & $-1,326146^{*}$ & 0,246233 \\
\hline DSUL & $1,391982^{*}$ & 0,187175 \\
\hline DNE*LOG(ST) & $-0,180319^{*}$ & 0,019900 \\
\hline DCO*LOG(ST) & $0,125541^{*}$ & 0,035486 \\
\hline DSUL*LOG(ST) & $-0,207642^{*}$ & 0,024661 \\
\hline DNE*LOG(EDUC) & 0,030704 & 0,057792 \\
\hline DCO*LOG(EDUC) & $0,384083^{*}$ & 0,118238 \\
\hline DSUL*LOG(EDUC) & $0,187748^{*}$ & 0,097276 \\
\hline $\mathrm{R}^{2}$ & 0,810236 & \\
\hline \multicolumn{3}{|c|}{ Equação Auxiliar } \\
\hline Constante & $5,484755^{*}$ & 0,078775 \\
\hline EDUC & $2,013054^{*}$ & 0,072175 \\
\hline DNE & $-0,163288 * *$ & 0,082447 \\
\hline DCO & $0,831817^{*}$ & 0,211880 \\
\hline DSUL & $0,985856^{*}$ & 0,209638 \\
\hline DNE*LOG(EDUC) & $-1,105660^{*}$ & 0,085442 \\
\hline DCO*LOG(EDUC) & $-0,657322 *$ & 0,194798 \\
\hline DSUL*LOG(EDUC) & $-1,321638^{*}$ & 0,167652 \\
\hline $\mathrm{R}^{2}$ & 0,611090 & \\
\hline
\end{tabular}

Todos os coeficientes das variáveis independentes e das variáveis dummy são altamente significativos nas equações de valor adicionado e valor adicionado per capita. Nas equações auxiliares, os coeficientes das dummy de intercepto das regiões CentroOeste e Sul não foram muito significativos, indicando que o intercepto nessas regiões não deve ser muito diferente do resto do país. No modelo per capita, apenas a dummy que mede o coeficiente de inclinação da região Nordeste não foi significativo. 
Os valores encontrados dos $R^{2}$ continuam altos, inclusive apresentando pequeno aumento de valor quando comparadas as equações geral e regionais do modelo sem dummy, com aumento mais sensível nas equações auxiliares. As estatísticas $\mathrm{F}$ permanecem altamente significativas.

\subsection{Testes $^{21}$ complementares}

\subsubsection{Verificando se o problema de heterocedasticidade foi corrigido}

Quando, anteriormente, fez-se a análise descritiva dos dados, foi constatada a necessidade de utilizar a forma logarítmica para evitar problemas de heterocedasticidade. Um primeiro teste ao modelo foi realizado para verificar se o problema foi de fato resolvido com esse procedimento.

O teste consiste em verificar se a dispersão das séries das variáveis, ou seja, a amplitude, depende da posição (mediana) ${ }^{22}$. As figuras 5,6 e 7 mostram que, sem utilizar as variáveis na forma logarítmica, a tendência seria da amplitude crescer à medida que a mediana aumenta. A linha traçada nos diagramas indica essa tendência.

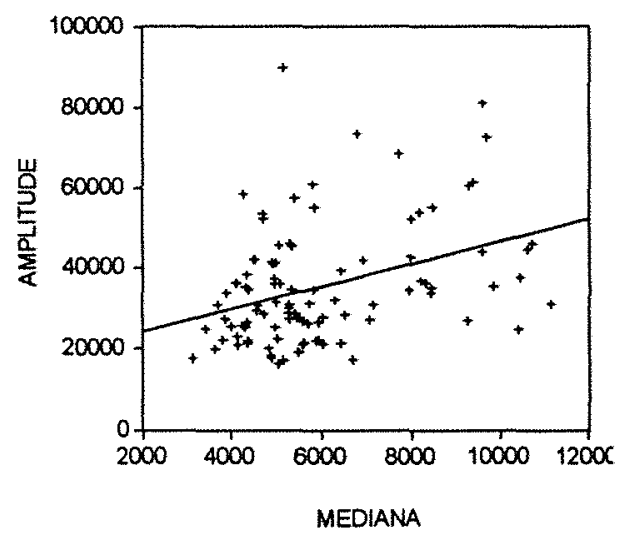

Figura 5 - Diagrama de dispersão da amplitude e mediana da variável EDUC2

${ }^{21}$ Os testes apresentados referem-se ao modelo para população total com variáveis dummy, os mesmos testes foram realizados, com resultados semelhantes, para os demais modelos total e per capita.

${ }^{22}$ As séries originais das variáveis, com 4638 observaçôes, foram divididas em 100 "sub-séries" de 46 observaçð̃es cada e 1 "sub-série" de 38 observaçðes, totalizando 101 "sub-séries". Para cada uma dessas "subséries" foram calculadas a mediana e a amplitude. Os pares foram plotados em diagramas de dispersão. A op̧̧ão pela amplitude e mediana para garantir a robustez das conclusões. Estes indicadores são menos sujeitos à influência de "outliers". Ver Mills (1990). 


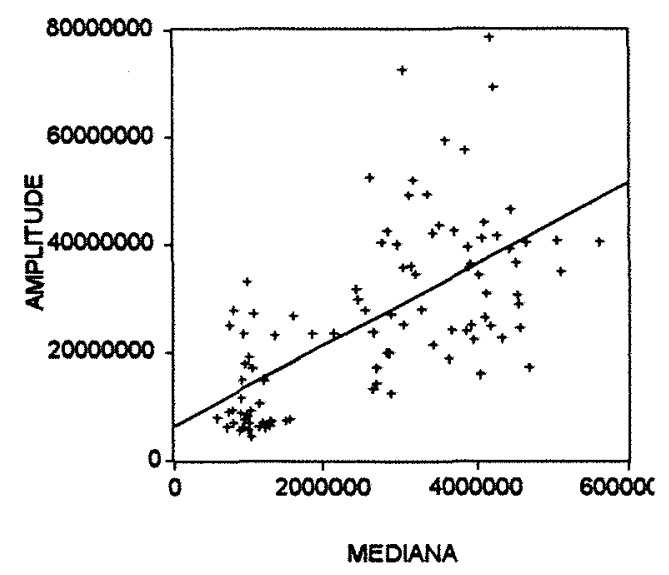

Figura 6 - Diagrama de dispersão da amplitude e mediana da variável SERV

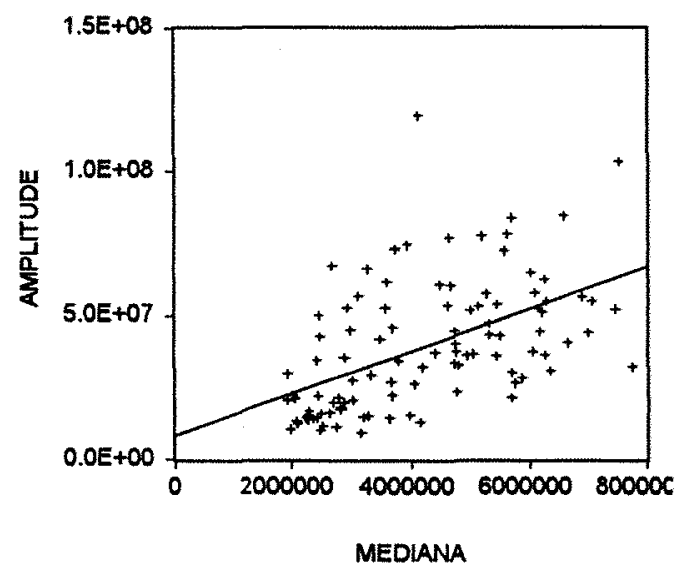

Figura 7 - Diagrama de dispersão da amplitude e mediana da variável VA

Quando as variáveis são utilizadas na forma logarítmica este problema é corrigido, como ilustram as figuras 8,9 e 10 . Nessas figuras percebe-se que a amplitude não mais depende significativamente da mediana. 


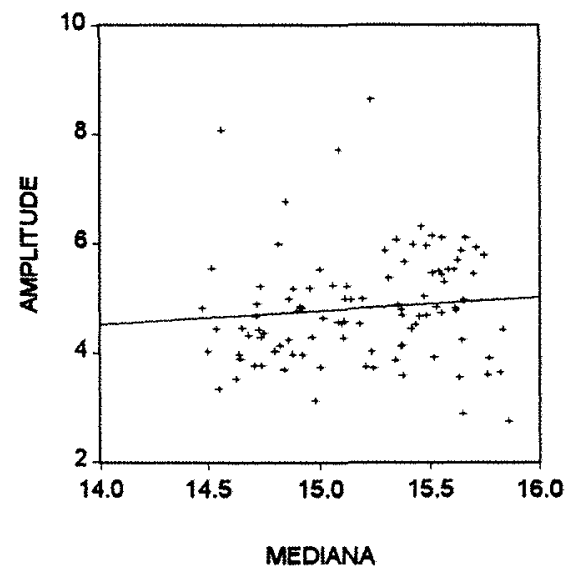

Figura 8 - Diagrama de dispersão da amplitude e mediana da variável EDUC2 na forma logarítmica.

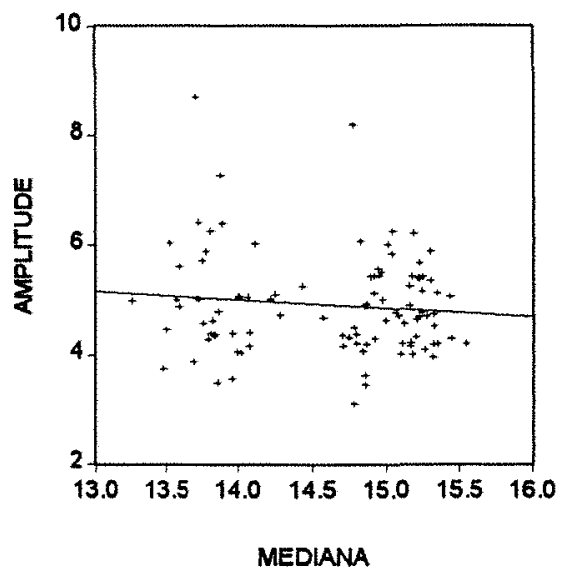

Figura 9 - Diagrama de dispersão da amplitude e mediana da variável SERV na forma logarítmica. 


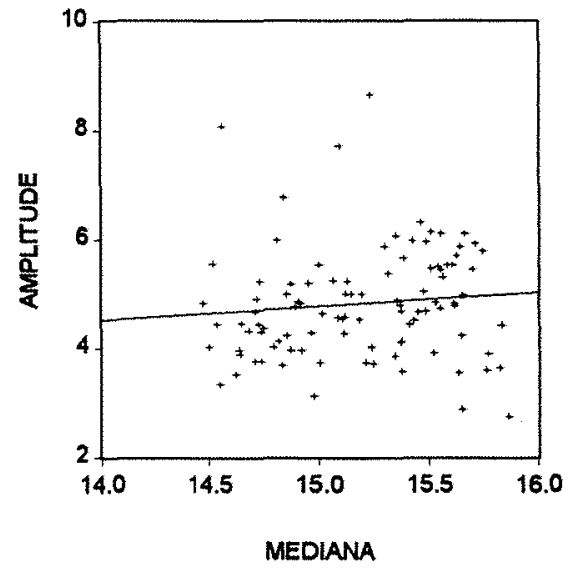

Figura 10 - Diagrama de dispersão da amplitude e mediana da variável VA na forma logarítmica

A inspeção visual das figuras indica que, utilizando as variáveis na forma logarítmica, a amplitude não depende mais da mediana. Para verificar formalmente esse resultado, foram estimadas equações com a amplitude em função da mediana. No caso das variáveis que não estão na forma logarítmica, os coeficientes de inclinação das medianas devem ser significativos, indicando que a mediana é importante fator para determinar a amplitude. Quando se toma o logaritmo das variáveis este coeficiente não deve ser significativo, indicando que a amplitude deixou de depender da mediana.

Os resultados da tabela 5 referem-se às equações com a amplitude como variável dependente e a mediana como variável independente das séries EDUC2, SERV e VA nas formas com e sem a aplicação de logaritmo ${ }^{23}$.

\footnotetext{
${ }^{23}$ O mesmo teste foi feito para as variáveis VAT, EDUC e ST, com resultados semelhantes.
} 
Tabela 5. Estimativa dos parâmetros e desvios-padrão da função amplitude para as séries da variáveis EDUC2, SERV e VA com e sem a aplicação do logaritmo.

\begin{tabular}{lcccccc}
\hline & $\begin{array}{c}\text { EDUC2 } \\
\text { Sem log. }\end{array}$ & $\begin{array}{c}\text { SERV } \\
\text { Sem log. }\end{array}$ & $\begin{array}{c}\text { VA } \\
\text { Sem log. }\end{array}$ & $\begin{array}{c}\text { EDUC2 } \\
\text { Com log. }\end{array}$ & $\begin{array}{c}\text { SERV } \\
\text { Com log. }\end{array}$ & $\begin{array}{c}\text { VA } \\
\text { Com log. }\end{array}$ \\
\hline $\mathrm{C}$ & $18653(4517)^{*}$ & $\begin{array}{c}6350420 \\
(2652209)^{* *}\end{array}$ & $\begin{array}{c}8345693 \\
(5471240)\end{array}$ & $4,84(2,65)$ & $7,14(2,08)^{*}$ & $0,97(3,95)$ \\
Mediana & $2,80(0,72)^{*}$ & $7,54(0,89)^{*}$ & $7,34(1,21)^{*}$ & $-0,065(0,30)$ & $-0,15(0,14)$ & $0,25(0,26)$ \\
$\mathrm{R}^{2}$ & 0,13 & 0,41 & 0,26 & 0,0004 & 0,011 & 0,009 \\
\hline
\end{tabular}

* indica que o coeficiente é significativo ao nível de $1 \%$

** indica que o coeficiente é significativo ao nível de $5 \%$

Os valores entre parênteses referem-se ao desvio-padrão.

O número de observaçðes é 101

Note que o coeficiente de inclinação da mediana é altamente significativo em todas as equações quando as variáveis não estão na forma logarítmica. Por outro lado, em nenhuma das equações, quando se toma o logaritmo das variáveis, esse coeficiente é significativo. Os valores dos $\mathrm{R}^{2}$ encontrados evidenciam que no caso sem logaritmo a mediana explica parcela importante da amplitude, enquanto no caso com logaritmo a mediana não explica a amplitude.

Esses resultados sugerem que o problema de heterocedasticidade foi de fato corrigido com o uso das variáveis na forma logarítmica. Para verificar se a amplitude dos resíduos do modelo ${ }^{24}$ não depende também da mediana foi utilizado o mesmo procedimento gráfico, como ilustra a figura 11.

${ }^{24}$ A série de resíduos utilizado refere-se ao modelo com variáveis dummy. O mesmo procedimento foi realizado para as séries dos resíduos dos demais modelos com resultados semelhantes. 


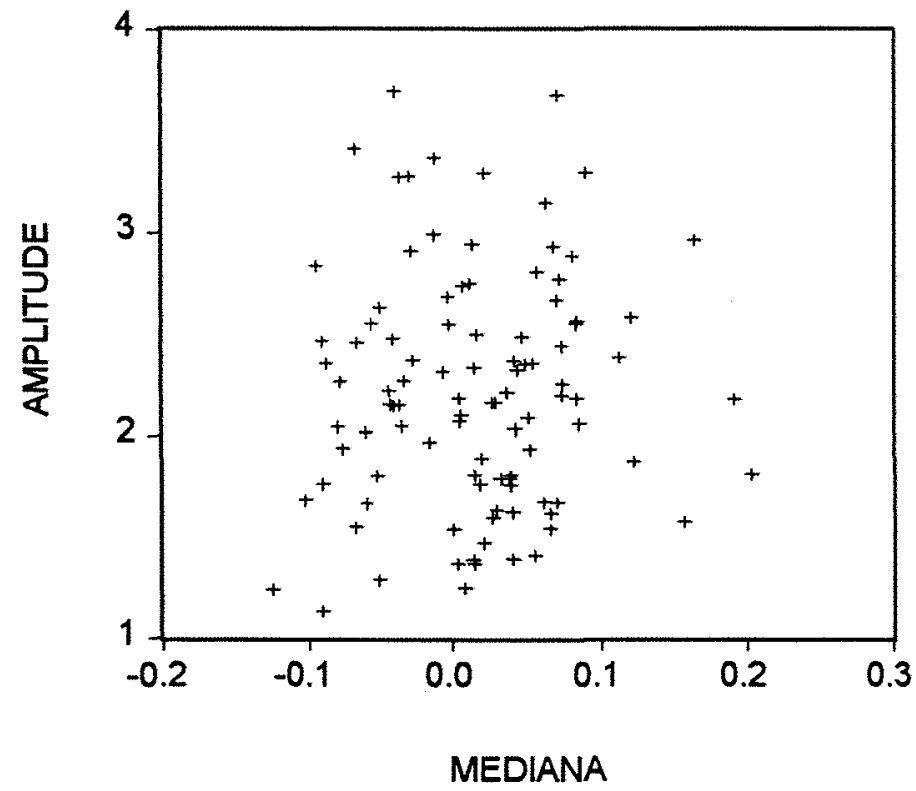

Figura 11 - Diagrama de dispersão da amplitude e mediana da série dos resíduos

Note que os pontos plotados no diagrama de dispersão formam uma nuvem sem qualquer padrão estabelecido, indicando que mediana e amplitude não apresentam qualquer relação de dependência. Todos esses resultados sugerem que a transformação logarítmica dos dados originais corrigiu o problema de variância não estável ${ }^{25}$.

\subsubsection{Testando a estabilidade do modelo ${ }^{26}$}

É necessário saber ainda se o modelo escolhido explica corretamente os dados em diferentes sub-amostras, ou seja, testar a estabilidade do modelo. $O$ teste utilizado foi o dos Resíduos Recursivos. Neste teste, a equação é estimada repetitivamente, utilizando sempre maiores subconjuntos da amostra de dados. Este procedimento fornece um retrato detalhado da evolução da relação estimada ${ }^{27}$.

${ }^{25}$ O mesmo procedimento foi realizado no modelo per capita e nas respectivas equações auxiliares obtendo os mesmos resultados.

${ }^{26} \mathrm{O}$ teste de estabilidade foi feito nos modelos sem as variáveis dummy, já que a inclusão destas impossibilita os cálculos necessários para o teste.

${ }^{27}$ Os procedimentos realizados nessa seção, cujos resultados estão ilustrados nas figuras 12 e 13, estão descritos no manual de instruçðes do pacote econométrico EVIEWS (Quantitative Micro Software, 1994). 
Considerando que $\mathrm{k}$ coeficientes são estimados em um vetor $\mathrm{b}$, as primeiras $\mathrm{k}$ observações são utilizadas para formar a primeira estimativa de b. Posteriormente, a próxima observação do conjunto de dados é adicionada e as $\mathrm{k}+1$ observações utilizadas para computar o valor do segundo $b$. Este processo é repetido até que todos os $\mathrm{T}$ pontos da amostra tenham sido utilizados, produzindo $\mathrm{T}-\mathrm{k}$ estimativas do vetor $\mathrm{b}$. A cada passo do processo a última estimativa de $\mathrm{b}$ pode ser utilizada para predizer o valor seguinte da variável dependente. Resíduo recursivo é definido como o erro nas previsões feitas a cada passo do processo.

O modelo será considerado válido, segundo os critérios deste teste, se os resíduos recursivos estiverem independentemente e normalmente distribuídos com média zero e variância $\sigma^{2}$.

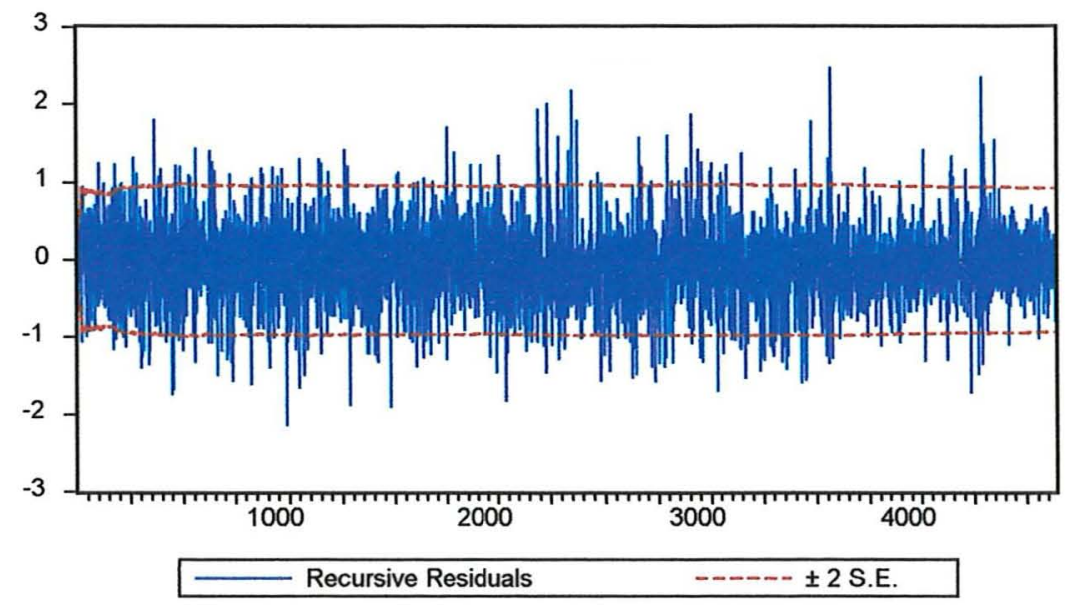

Figura 12 - Teste dos resíduos recursivos

$\mathrm{O}$ resultado do teste, ilustrado na figura 12 , mostra que não há evidências de problemas de estabilidade no modelo. Para assegurar que o modelo é estável, foi realizada, ainda, a estimativa dos coeficientes recursivos. Este teste mostra os coeficientes selecionados na equação para todas as possíveis estimações recursivas.

A figura 13 ilustra os resultados do teste dos coeficientes recursivos. As duas bandas que aparecem na figura ao redor dos coeficientes estimados representam o desvio-padrão. Se os coeficientes apresentam variação significativa, quando mais dados 
são adicionados na estimativa das equações, há forte indício de instabilidade. Note, na figura 13, que isso não ocorre indicando que não há problemas de estabilidade. Não há também grandes saltos o que poderia indicar alguma quebra estrutural no modelo.
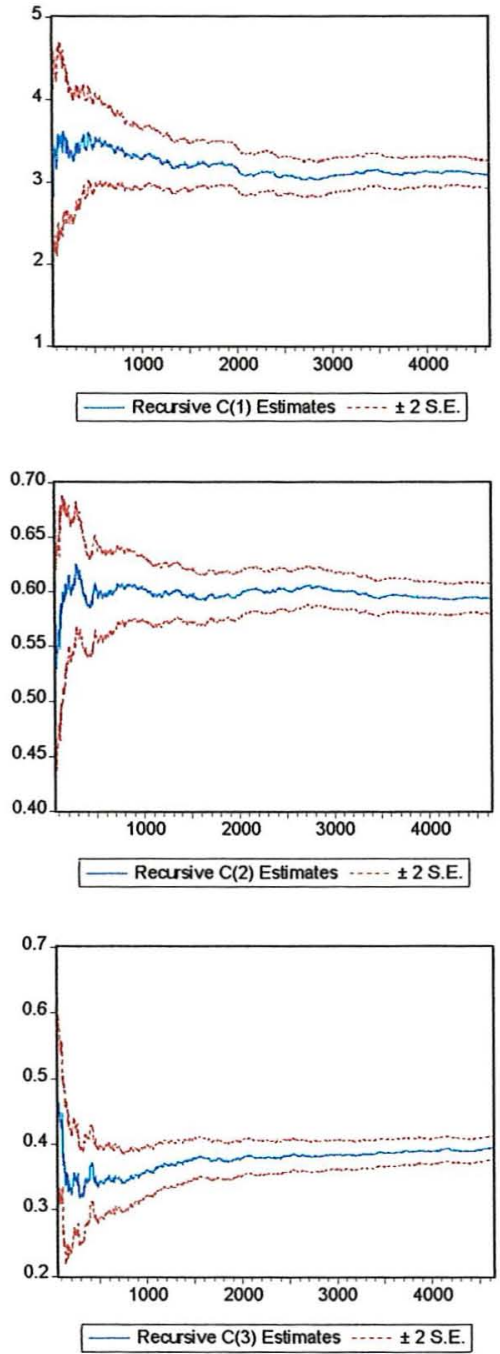

Figura 13 - Teste dos coeficientes recursivos

\subsection{Análise econômica dos resultados}

Os valores dos parâmetros encontrados nas equações estimadas indicam que a educação, como previsto por Welch, desempenha importante papel como insumo na 
produção agrícola. Aumentar a qualidade da mão-de-obra é uma medida política eficiente quando a meta é melhorar o desempenho produtivo dos agricultores e trabalhadores agrícolas.

O estudo de Patrick \& Kehrberg (1975) não apresenta resultados animadores quanto ao investimento em educação ser o melhor uso para os recursos escassos. Isso porque em três das cinco áreas estudadas os retornos da escolaridade na agricultura foram nulos ou negativos. Mesmo nas duas áreas onde os retornos da escolaridade foram positivos, os coeficientes encontrados foram baixos, indicando que a escolaridade pode não ter grande influencia sobre o valor adicionado da agricultura. Os coeficientes apresentados no estudo de Conceição \& Araújo (1993) também são baixos e não foram significativos em duas das três áreas estudadas.

Patrick \& Kehrberg ressaltam que seus resultados estatísticos e a limitada área geográfica estudada impossibilitam conclusões sólidas sobre o papel da educação. Portanto, com base nesses estudos é difícil afirmar que a educação desempenha importante papel na produção agrícola.

Por outro lado, o grande número de informações utilizadas neste estudo e a abrangência geográfica, todas as regiões agrícolas do Brasil estão incluídas, dão aos resultados grande confiabilidade. Os coeficientes de escolaridade são relativamente altos indicando que a escolaridade tem influencia relevante sobre o valor adicionado na agricultura.

O efeito indireto, ou alocativo, calculado com base na equação 26 , considerando o pais todo, é extremamente importante e contribui para o aumento do valor do produto adicionado na agricultura mais que o próprio efeito direto. Isso não é verdade apenas nas regiões que praticam agricultura tradicional, como o Norte e o Nordeste. Estes resultados são coerentes com a hipótese que em áreas agrícolas mais dinâmicas e modernas a educação possibilita aos produtores a escolha e adoção de insumos tecnicamente superiores, além de possibilitar ao agricultor alocar eficientemente, entre usos alternativos, os insumos novos e os já existentes. 
Nas áreas onde predomina a agricultura tradicional o efeito direto é maior que o efeito indireto bruto da educação. Isto ocorre nas regiões Norte/Nordeste e Sul. Nas outras regiões e para o país como um todo o efeito indireto bruto foi superior ao efeito direto.

Apesar da região Sul apresentar efeito direto bruto da educação superior ao efeito indireto, esta diferença é muito pequena, provavelmente porque existem importantes áreas de agricultura moderna na região convivendo com outras onde predomina agricultura tradicional.

O modelo utilizando variáveis dummy confirma os resultados encontrados nas equações regionais. Novamente, a região Norte/Nordeste apresenta efeito direto superior ao efeito indireto. No modelo per capita, esse fato não foi verificado. No entanto, neste modelo, o coeficiente de inclinação, dummy nordeste multiplicado pela educação, não foi significativo. Na região Sul, os efeitos direto e indireto seguem muito próximos. Nas demais regiões, como ocorreu anteriormente, existe forte superioridade do efeito indireto.

Nas equações de valor adicionado per capita (tabela 2), e per capita utilizando variáveis dummy (tabela 4), o efeito indireto bruto da educação foi superior ao efeito direto em todas as regiões e para o país como um todo. Nas regiões Norte/Nordeste e Sul a superioridade deste efeito indireto foi pequena, principalmente quando comparada com as regiões Sudeste e Centro-Oeste, não invalidando, portanto, a hipótese de o efeito direto ser mais importante nas regiões tradicionais que nas regiões modernas.

Nas áreas de agricultura moderna o efeito total que a educação exerce sobre o valor adicionado na agricultura é maior que o encontrado nas áreas de agricultura tradicional. Esse fato sugere que o aumento da educação da população agrícola deve favorecer as regiões modernas, podendo aumentar ainda mais a vantagem comparativa dos agricultores dessas regiões frente àqueles que praticam agricultura tradicional.

O efeito combinado do mecanismo de autocontrole, que inibe a adoção de técnicas modernas por parcela não desprezível dos agricultores (Paiva, 1975), citado 
anteriormente, com a vantagem que as regiões modernas apresentam diante do aumento da escolaridade da população agrícola, deve ser o aumento da superioridade dos agricultores modernos frente aos tradicionais. Esse argumento sugere que, ao se elevar a escolaridade das populações agrícolas, parcela ainda maior de agricultores tradicionais pode ser obrigada a deixar a atividade.

No entanto, mesmo as regiões modernas tornando-se ainda mais dinâmicas, transferir trabalhadores das áreas de agricultura tradicional para regiões de agricultura moderna não parece ser o melhor caminho a melhores condições de vida e emprego desses trabalhadores. $\mathrm{O}$ trabalhador deve estar preparado para buscar oportunidades de emprego fora da agricultura, o que só ocorrerá se estas pessoas estiverem devidamente qualificadas.

Pode-se contra-argumentar essa afirmação com o fato histórico de ter sido intensa a migração rural-rural no Brasil após a segunda guerra mundial. Nessa época, houve uma saída forçada de recursos humanos das regiões de agricultura tradicional, principalmente do Nordeste, Leste e extremo Sul, em direção a áreas, que na ocasião eram de fronteira agrícola, Paraná, sul de Goiás e Mato-Grosso.

No entanto, esse movimento foi condicionado principalmente pelo ambiente político da época, quando uma das metas dos planejadores era justamente promover o povoamento do interior, e devido a incapacidade da indústria absorver o excedente de mão-de-obra na velocidade que seria necessária. Além desses, outros fatores que determinavam o cenário político e econômico específicos daquele período, explicam o fato da taxa acelerada de migração ter ocorrido dentro do próprio setor agrícola (ver, por exemplo, Schuh, 1977).

As condições que propiciaram este movimento não existem nos dias atuais. Desta forma, este argumento não parece invalidar a necessidade de se estimular a ida dos trabalhadores agrícolas para o setor não agrícola. Vale ressaltar que, movimentos migratórios dentro do próprio setor agrícola, principalmente em direção a áreas de fronteira agrícola que ainda existem no Brasil, deverão continuar a ocorrer, mas sua 
importância relativa, em termos de capacidade de absorver mão-de-obra, parece ser declinante.

A opção dos trabalhadores encontrarem ocupações não-agrícolas no próprio meio rural, possibilitando inclusive que dediquem parte do tempo à agricultura e parte do tempo às ocupações não agrícolas, é uma alternativa que deve ser estudada com maior profundidade. A questão das migrações rumo as fronteiras agrícolas e a própria contribuição que a ampliação da área cultivada tem dado ao desenvolvimento do setor agrícola são temas interessantes e importantes.

Outra questão importante, salientada por Conceição \& Araújo (1993), é a importância da educação no processo de formação de capital. Nas regiões de maior dinamismo da atividade agropecuária esse fator é ainda mais importante. Os resultados apresentados aqui coincidem com o estudo de Conceição \& Araújo (1993).

Os resultados de Patrick \& Kehrberg (1975) também confirmam que os recursos fornecidos pelo estabelecimento agrícola são afetados pela educação. No entanto, os autores destacam que "dado o elevado custo da educação, poder-se-ia argumentar que aqueles agricultores que eram filhos de pais abastados poderiam ter tido oportunidade de obter um nível de instrução mais elevado e também ter recebido inicialmente mais recursos".

Vale ressaltar que nas regiões Norte e Nordeste, onde está concentrada a maior parcela da população com baixo nível de escolaridade, o aumento de produção em resposta aos aumentos nos gastos com educação são menores. Portanto, com menor resposta aos investimentos, o incentivo econômico para aumentar os gastos com educação é menor nessas regiões. Considerando que nessas regiões os investimentos em educação já alcançam valores elevados em relação ao PIB, parece ser reduzida e preocupante a capacidade econômica dos estados e municípios destas regiões aumentarem os investimentos na área educacional. 


\section{CONCLUSÕES}

Parcela significativa da população brasileira permanece na agricultura, ocupada em atividades que não permitem remuneração ou que apenas garantem sua sobrevivência. $O$ estudo da natureza do processo de desenvolvimento da agricultura mostra serem remotas as possibilidades do pequeno agricultor tradicional modernizar sua produção e permanecer na atividade de maneira competitiva.

O mercado de trabalho não agrícola, por outro lado, exige mão-de-obra de qualidade, o que não é característica dessa parcela da população, em geral apresentando baixa escolaridade. Não educar significa condenar estes trabalhadores a uma vida de luta pela sobrevivência na agricultura tradicional.

Os resultados encontrados neste estudo mostram que aumentar a educação das populações rurais contribui para o desenvolvimento da agricultura ao possibilitar maior produção. $\mathrm{O}$ alto retorno econômico encontrado para os investimentos em educação mostra ser esta uma estratégia adequada para o uso dos recursos escassos.

O retorno da educação consiste de dois efeitos: "efeito trabalhador", ou efeito direto; e, "efeito alocativo", ou efeito indireto. O efeito indireto, no geral, foi mais importante que o efeito direto, exceto para regiões onde predomina a agricultura tradicional. Nessas áreas, a disponibilidade de técnicas alternativas pode ser limitada, fazendo com que a maior capacidade de tomada de decisão e gerência desenvolvida pela educação não seja inteiramente aproveitada.

Melhorar os serviços de extensão rural, disponibilizando aos agricultores novas técnicas de produção, principalmente nas áreas de agricultura tradicional, pode ser uma 
política complementar ao aumento da escolaridade. Dessa forma, os agricultores poderão usufruir de forma mais ampla os benefícios que o aumento da escolaridade proporciona.

O mesmo raciocínio parece válido para os investimentos em pesquisa que, em conjunto com maior escolaridade e melhores serviços de extensão, deve melhorar os retornos dos investimentos em educação. Estudar melhor as relações entre pesquisa, extensão rural e educação com a produção agropecuária, inclusive procurando explorar as diferenças regionais, é tema interessante que fica como sugestão para futuros estudos.

O aumento da escolaridade das populações rurais, uma vez que seu efeito total sobre o produto agrícola é mais acentuado nas áreas de agricultura moderna, deve aumentar ainda mais a vantagem comparativa dos agricultores modernos sobre os tradicionais. Neste sentindo, as áreas de agricultura tradicional tendem a ter cada vez menos incentivo a adotar tecnologia, tornando mais difícil a permanência desses agricultores na atividade.

O menor retorno aos investimentos em educação e a pequena capacidade de financiamento das esferas de governo locais nas áreas de agricultura tradicional, sobretudo nas regiões Norte e Nordeste, preocupam quanto a questão da viabilização dos investimentos necessários nessas regiões. Como grandes problemas de pobreza e baixa escolaridade ocorrem nestas regiões, especial atenção deve ser voltada para estes trabalhadores.

Os resultados apresentados referem-se a apenas um momento no tempo, todos os dados são do ano de 1995. Assim, não foi possível avaliar como as taxas de retorno aos investimentos em educação se alteram ao longo do tempo. Comparar diferentes momentos no tempo pode trazer informações importantes podendo ser assunto para futuros estudos.

A educação é um investimento que não traz beneficios apenas no curto-prazo, ao contrário, as vantagens econômicas de aumentar a escolaridade da população devem ser percebidas no longo-prazo. Estudar diferentes momentos no tempo deverá permitir 
calcular, também, as elasticidades de curto e longo prazos, o que deve contribuir para o melhor entendimento das relações econômicas entre a educação e o produto social da agricultura.

Lutar por metas que estão além das necessidades e anseios do curto-prazo, talvez seja o melhor caminho para, ao olhar o passado, sentir mais do que tristeza por saber que tantas pessoas viveram suas vidas na pobreza, orgulho por superar um período da história quando parcela significativa da população brasileira esteve condenada à Morte e Vida Severina. 


\section{REFERÊNCIAS BIBLIOGRÁFICAS}

ALVES, E. Migração rural-urbana. Revista de Política Agrícola, v.4, n.4, p.15-19, out./dez. 1995.

ARAÚJO, P.F.C.; SCHUH, G.E. Desenvolvimento econômico e agricultura. Fundamentos de Economia Agrícola. Piracicaba: ESALQ/USP, 1991. cap.4.

ARROW, K.J. The economic implications of learning by doing. The Review of Economic Studies, v.39, n.3, p.155-173, June 1962.

BARRO, R.J. Government spending in a simple model of endogenous growth. Journal of Political Economy, v.98, n.5, p.103-125, 1990.

BARRO, R.J. Economic growth in a cross section of countries. The Quartely Journal of Economics, p.407-443, May 1991.

BARROS, R.P. de; CRUZ, L.E.M.; FOGUEL, M.N.; MENDONÇA, R.S.P. de. Uma avaliação empírica do grau de flexibilidade alocativa do mercado de trabalho brasileiro. Rio de Janeiro: IPEA, Julho 1997a. (Texto para Discussão, 499)

BARROS, R.P. de; FOGUEL, M.N.; MENDONÇA, R.S.P. de. Perspectivas para 0 mercado de trabalho brasileiro ao longo da próxima década.. Rio de Janeiro: IPEA, Nov. 1997b. (Texto para Discussão, 526) 
BARROS, R.P. de; MENDONÇA, R.S.P. de. Investimentos em educação e desenvolvimento econômico. Rio de Janeiro: IPEA. Nov. 1997c. (Texto para Discussão, 525)

BEALS, R.; LEVY, M.; MOSES, L. Rationality and migration in ghana. The Review of Economics and Statistics, v.49, n.4, p.480-486, Nov. 1967.

BECKER, G. Human capital: a theoretical and empirical analysis with special reference to education. 3 ed. Chicago: The University of Chicago Press, 1993.

BECKER, G.; MURPHY, K.M.; TAMURA, R. Human capital, fertility, and economic growth. Journal of Political Economy, v.98, n.5, p.12-37, 1990.

BRASIL. Ministério da Educação. Lei n.9394 de 20 de dezembro de 1996. Lei de diretrizes e bases da educação.

CACCIAMALI, M.C. Mudanças estruturais e o ajustamento do mercado de trabalho no Brasil na década de oitenta. Estudos Econômicos, v.22, n.especial, p.133-155, 1992.

CASTRO, C.M. Investimento em educação no Brasil: comparação de três estudos. Pesquisa e Planejamento Econômico, v.1, n.1, p.141-152, jun/nov. 1971.

CASTRO, J.A. de; FERNANDES, M.A.C. Sistema de informações sobre os gastos públicos na área de educação - SIGPE: diagnóstico dos gastos públicos na área de educação - 1995. Brasília: Instituto de Pesquisa Econômica Aplicada, 1999.

CONCEIÇÃO, J. C. P. R. da; ARAÚJO, P.F.C. O papel da educação e da extensão rural no desempenho da atividade agropecuária em regiões selecionadas do Brasil. 
/Apresentado ao departamento de Economia, Administração e Sociologia da Escola Superior de Agricultura "Luiz de Queiroz" - USP, na disciplina Tópicos Especiais em Economia Agrícola, Piracicaba, 1993/

DE JANVRY, A. Social structure and biased technical change in Argentina agriculture. In: BISWANGER, H.P.; RUTTAN, V.W. (Ed.) Induced Inovations. The Johns Hopkins Úniversity Press, 1978, p.297-326.

FAO. FAO Statbase. http: //apps.fao.org/ggi-bin/nph-db.pl (08/05/2000).

FEI, J.C.H; RANIS, G. Agrarianismo, dualismo e desenvolvimento econômico. In: ARAÚJO, P.C.; SCHUH, G.E. (Ed.) Desenvolvimento da agricultura: natureza do processo e modelos dualistas. Piracicaba: Livraria Pioneira Editora, 1975. v.1, p.101-136.

GIBBON, V.H. Taxas de retorno dos investimentos em educação no Brasil: uma análise desagregada. Revista Brasileira de Economia, v.29, n.3, p.109-133, jul./set. 1975.

GREENWOOD, M. An analysis of the determinats of geographic labor mobility in the United States. The Review os Economics and Statistics, v.51, n.2, p.189-194, May 1969.

GRILICHES, Z. Hybrid corn: an exploration in the economics of technological change. Econometrica, v.24, n.4, p.501-522, 1957.

GRILICHES, Z. Despesas em pesquisa e educação na função de produção agrícola agregada. In: ARAÚJJO, P.C.; SCHUH, G.E. (Ed.) Desenvolvimento da agricultura: educação, pesquisa e assistência técnica. Piracicaba: Livraria Pioneira Editora, 1975. v.2, p.101-116. 
GUJARATI, D. Basic econometrics. 3 ed. McGraw-Hill. 1995. 838p.

HARRIS, J.; TODARO, M. Migration, unemployment and development: a two-sector analysis. American Economic Review, v.60, p.126-142, 1970.

HAYAMI, Y; RUTTAN, V. Desenvolvimento agrícola: teoria e experiências internacionais. Brasília: EMBRAPA, 1988.

HOPPER, W.D. Eficiência na alocação de recursos em uma agricultura tradicional da Índia. In: ARAÚJO, P.C.; SCHUH, G.E. (Ed.) Desenvolvimento da agricultura: natureza do processo e modelos dualistas. Piracicaba: Livraria Pioneira Editora, 1975. v.1, p.67-81.

INSTITUTO BRASILEIRO DE GEOGRAFIA E ESTATÍSTICA. Censo Agropecuário 1995-96. http://www.ibge.gov.br/ estatistica/economia/agropecuaria/ censoagro/default.shtm (08/05/2000).

INSTITUTO BRASILEIRO DE GEOGRAFIA E ESTATÍSTICA. Contagem populacional 1996.http://www.ibge.gov.br/estatistica/populacao/contagem/default. $\operatorname{shtm}(08 / 05 / 2000)$.

INSTITUTO BRASILEIRO DE GeOGRAFIA E eStatístiCA. Pesquisa Nacional por Amostragem de Domicílios. http:// www.sidra.ibge.gov.br (08/05/2000).

JOHNSTON, B.F.; MELLOR, J.W. The role of agriculture in economic development. American Economic Review, v.51, p.566-593, Sep. 1961.

JORGENSON, D.W. Teste de teorias alternativas de desenvolvimento em economia dualista. In: ARAÚJO, P.C.; SCHUH, G.E. (Ed.) Desenvolvimento da agricultura: 
natureza do processo e modelos dualistas. Piracicaba: Livraria Pioneira Editora, 1975. v.1, p.137-152.

KASSOUF, A.L. Retornos à escolaridade e ao treinamento nos setores urbano e rural do Brasil. Revista de Economia e Sociologia Rural, v.35, n.2, Abr./Jun. 1997.

LANZONA, L. Migration, self-selection and earnings in Philippine rural communities. Journal of Development Economics, v.56, p.27-50, 1998.

LUCAS, R.E. Making a miracle. Econometrica, v.61, n.2, p.251-272, Mar. 1993.

MAGALHÃES, A.; BRANDT, S.A.; MAIA, M.M. Absorção de trabalho, demanda e decomposição do emprego agrícola. Estudos Econômicos, v.16, n.2, p.243-255, Maio/Ago. 1986.

MANKIW, N.G.;ROMER, D.; WEIL, D.N. A contribution to the empirics economic growth. Quarterly Journal of Economics, p.407-437, 1992

MILLS, T.C. Time series techiniques for economists. New York: Cambridge University Press, 1990. cap.4, p.40-60.

MUELLER, C.C.; MARTINE, G. Modernização da agropecuária, emprego agrícola e êxodo rural no Brasil: a década de 1980. Revista de Economia Política, v.17, n.3, p.85-104, jul./set. 1997.

MURPHY, K.M.; SHLEIFER, A.; VISHNY, R.W. The allocation of talent: implications for growth. Quarterly Journal of Economics, p.503-530, May 1991. 
NICHOLLS, W.H. O excedente agrícola como fator de desenvolvimento. In: ARAÚJO, P.C.; SCHUH, G.E. (Ed.) Desenvolvimento da agricultura: natureza do processo e modelos dualistas. Piracicaba: Livraria Pioneira Editora, 1975. v.1, p.3-38.

OWEN, W.F. A dupla pressão do processo de desenvolvimento econômico sobre a agricultura. In: ARAÚJO, P.C.; SCHUH, G.E. (Ed.). Desenvolvimento da agricultura: natureza do processo e modelos dualistas. Piracicaba: Livraria Pioneira Editora, 1975. v.1, p.39-65.

PAIVA, R.M. Modernização e dualismo tecnológico na agricultura: uma reformulação. Pesquisa e Planejamento Econômico, v.5, n.1, p.117-162, 1975.

PATRICK, G.F.; KEHRBERG, E.W. Custos e retornos da educação em cinco áreas agrícolas da região leste do Brasil. In: ARAÚJO, P.C.; SCHUH, G.E. (Ed.) Desenvolvimento da agricultura: educação, pesquisa e assistência técnica. Piracicaba: Livraria Pioneira Editora, 1975. v.2, p.17-34.

QUANTITATIVE MICRO SOFTWARE. Programa Econometric Views - EVIEWS, version 2.0. 1994.

REBELO, S.; KING, R.G. Public policy and economic growth: developing neoclassical implications. Journal of Political Economy, v.98, n.5, p.126-150, 1990.

ROMER, P.M. Increasing returns and long-run growth. Journal of Political Economy, v.94, n.5, 1986.

SAHOTA, G. An economic analysis of internal migration in Brazil. The Journal of Political Economy, v.76, n.2, p. 218-245, Mar./Apr. 1968. 
SCHUH, G.E. Modernização da agricultura brasileira. In: ARAÚJO, P.C.; SCHUH, G.E. (Ed.) Desenvolvimento da agricultura: análise de política econômica. Piracicaba: Livraria Pioneira Editora, 1977. v.3, p.281- 311.

SCHULTZ, T.W. Reflections on investment in Man. The Journal of Political Economy, v.70, n.5, part 2, Oct. 1962.

SCHULTZ, T.W. Transforming tradicional agriculture. New Haven: Yale University Press, 1964.

SCHULTZ, T.W. O capital humano: investimentos em educação e pesquisa. Trad. Marco Aurélio de Moura Matos. Rio de Janeiro: Zahar Editores, 1973. 250p.

SINGH, R.D. Retornos diretos e alocativos da educação e a demanda educacional familiar para crianças do meio rural no Brasil. Revista de Economia e Sociologia Rural, v.27, n.2, abr.jun. 1989.

SJAASTAD, L.A. The costs and return of human migration. the journal of political economy, v.70, n.5, part 2, p.80-93, Oct. 1962.

STERN, N. The determinants of growth. The Economic Journal, v.101, p.122-133, Jan. 1991.

STOKEY, N. L. Human capital, product quality, and growth. Quartely Journal of Economics, v.106, n.2, p.587-616, May 1991.

VANDERKAMP, J. Migration flows, their determinants and the effects os return migration. Journal of Political Economy, v.79, n.5, p.1012-1031, Sep./Oct. 1971. 
WELCH, F. Education in production. Journal of Political Economy, v.78, n. 1, p.35-59, Jan./Feb. 1970. 